U. S. DEPARTMENT OF AGRICULTURE.

S B

191

. M2S65

\title{
THE INFLUENGE OF ENVIRONMENT ON THE COMPOSITION OF SWEET CORN, 1905-1908.
}

By

\section{N. STRAUGHN AND C. G. CHURCH, Assistant Chemists, Sugar Laboratory,}

UNDER THE DIRECTION OF

H. W. WILEY,

Chicf of Burcau.

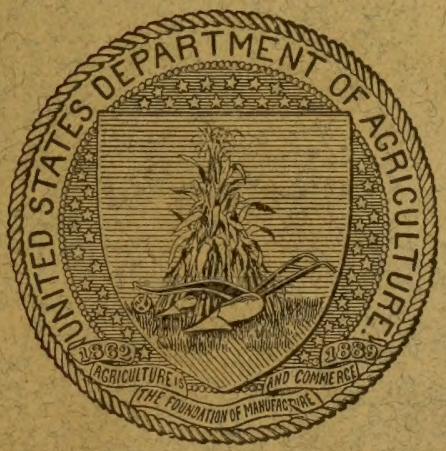

WASHINGTON:

GOVERNMENT PRINTING OFEICE.

1909. 


$$
\%
$$





U. S. DEPARTMENT OF AGRICULTURE. BUREAU OF CHEMISTRY-BULLETIN No. $12 \%$.

H. W. WILEY, Chief of Bureau.

\section{THE INFLUENCE OF ENVIRONUENT ON THE COIIPOSITION OF SWEET CORN, 1905-1908.}

By

M. N. STRAUGHN ANd C. G. CHURCH, Assistant Chemists, Sugar Laboratory,

UNDER THE DIRECTION OF

H. W. WILEY,

Chief of Bureau.

WASHINGTON:

GOVERNMENT PRINTING OFFICE.

1909 . 


$$
53 m^{29 !} 5^{65}
$$

DEC \& isu

Dof of

$\operatorname{agr} 9-3102$ 


\section{LETTER OF TRANSMITTAL.}

\section{U. S. Department of Agriculture, \\ Bureau of Chemistry, \\ Washington, D. C., March 6, 1909.}

SIR: I have the honor to submit a report on the continuation of the studies on the effects of environment on the composition of crops, carried on by Messrs. Straughn and Church under my personal direction and in collaboration with the Bureau of Plant Industry and the agricultural experiment stations of Florida, South Carolina, Maryland, Connecticut, New Jersey, and Maine. The manuscript submitted for your inspection and approval at the present time relates to a four years' study of the effect of environment on the sugar content of Indian corn at the stage of development and succulence when it is generally used for food.

I recommend that the manuscript be published as Bulletin No. 127 of the Bureau of Chemistry.

Respectfully,

Hon. James Wilson, Secretary of Agriculture.
H. W. WILEY, Chief of Bureau. 



\section{INTRODUCTION}

On the completion of the work connected with the study of the effect of environment on the sugar content of the beet, ${ }^{a}$ it was deemed advisable in the interests of economy and efficiency to collaborate in other studies of this kind with the Bureau of Plant Industry. The increasing volume of executive work in the Bureau of Chemistry rendered it impossible for the Chief of the Bureau to give as much of his personal attention to the study as he had previously done. Accordingly an arrangement was made with the Bureau of Plant Industry whereby the Bureau of Chemistry would assist the Bureau of Plant Industry in its work of improvement by selection of sweet Indian corn, and the Bureau of Plant Industry undertook to grow the crops and give this Bureau full opportunities for studying the effect of environment on the composition of the sweet corn, both in its succulent state as used upon the table and after maturing.

Messrs. Straughn and Church, the latter having worked with the Chief of the Bureau of Chemistry in studying the effects of environment on the sugar content of beets, were accordingly detailed to perform the chemical part of the collaborative work. The general plan pursued in the former studies was followed in those which are reported here.

The factors which are most effective in influencing the composition of the crop are length of day, with its concomitants, the amount and distribution of sunshine, the altitude, the temperature, and the amount and distribution of rainfall. As in the previous studies, we are indebted to the Weather Bureau for the meteorological data, to the Coast and Geodetic Survey for the computation of the length of day and the altitude and latitude of the stations, and to the agricultural experiment stations in the various States where the crops were grown, and the preliminary analyses made. It is only by such collaboration that problems of this kind which necessarily extend over wide areas can be successfully studied.

The data which have been collected have been secured principally along the Atlantic coast, extending from Maine to Florida. Similar data are desirable for conditions in different longitudes, as well as in different latitudes, since the conditions which obtain in the interior

$a$ U. S. Dept. Agr., Bureau of Chemistry, Bul. Nos. 64, 74, 78, 95, and 96. 
of the continent may affect in a marked degree the character of the product.

The distribution of the work from north to south rendered it possible for the same analysts to perform the chemical analyses in the different localities. Beginning with the earliest harrest in Florida, the same workers followed the ripening crop from Florida to South Carolina, Maryland, New Jersey, Connecticut, and finally to Maine.

One of the most important points in connection with this study was that the analytical work be done as quickly as possible after the harresting of the crop. Previous work had shown a rapid change, especially in the sugar content of the green Indian corn, after its separation from the stalk, and particularly if exposed to a high temperature. It was necessary, therefore, where no chemical laboratory was available, to have a portable laboratory, so that the analyses could be made as soon as the corn was harrested. In this way the errors which would necessarily occur in examining the samples at different periods after harvesting were avoided. As it was quite impossible to perform all the analytical operations on many hundreds of samples in the field, only those analyses were made which could be speedily completed, and the samples were preserved in such a way as to protect them from any appreciable change until the more elaborate chemical work could be accomplished. By the course of experiments which preceded the beginning of this work it was found that the best, simplest, and easiest way of preserving these samples is immediately to boil them in alcohol. This not only prevents all enzymic and other destructive action but also protects the samples from fermentation until such time as they can be more carefully examined.

There are many points relating to the influence of environment which are not covered by these investigations. It seemed wiser not to complicate the problem by undertaking too many lines of study. Sweet Indian corn is valued as a table dish on account of its succulence, tenderness, and sweetness, and these were the points to which particular attention was directed. Organoleptic tests were made in addition to the chemical determinations as to the sweetness and general character of the product and it is interesting to note that the results of these agreed in nearly every instance with the chemical determinations. In other words, the trained palate, while not able to determine the percentage of sugar in such a product as sweet Indian corn, was at least able to note the samples as poor, good, or excellent, and the chemical analyses bore out the classification thus made.

This line of work has been continued now for a number of years with excellent practical results. It has, the writer believes, marked out a new course of agricultural investigations which, in the future, 
will do much for the progress of agricultural sciences. It is true that in some small countries the rariations in the environment are not sufficiently great to enable studies of a similar character to be carried on, yet there are many single States in our own country whose areas and consequent variations of environment are sufficient to permit studies of great value to be carried on within their borders. As an illustration of this, Texas, for instance, affords such variations in environment that studies of this kind might be undertaken within its borders. Fortunately, by reason of the relations which exist between the central government and the various States in this country it is an easy matter to secure the collaboration of a sufficient number of States to widely extend these studies of environment. [ndoubtedly similar collaborative studies could be profitably made by countries. For instance, on the continent of North America it might be very easy to interest both the Dominion of Canada and Mexico in studies of the effect of environment on the composition of plants which would grow in all three countries. Thus the line of study which has been indicated by these investigations may be pursued in the future with much more useful results by others.

It is evident that the character of a food plant, as far as its physical and organoleptic properties are concerned, is largely the result of chemical composition. Hence it follows that if we can place in the hands of the farmer the means of influencing this chemical composition much may be accomplished toward the improvement of plants and their adaptability to the particular purpose for which they are intended. Combined as this study naturally is with that of selection for improvement, it affords an almost perfect means of variation at the will of the experimenter who may have at his disposal the variations in environment which are dominant in producing chemical change. While perhaps it is idle to look forward to a time when the environment itself may be subject to variation through human means, it is not difficult, in a limited way, to produce changes in environment at the present time by growing plants under glass. Thus a way may be opener for studying effects of environment within a very small area of the United States. While such a study would be full of the greatest scientific interest, it could not possibly have the same practical value as a study made under natural conditions.

The original plan under which these studies were mapped out included also studies of the effect of environment on the protein content of cereals and the sugar content of melons. Much preliminary work has been done along these lines, but not enough to warrant publication at the present time. The data secured show, however, that these are promising fields of research. 
These investigations are of more than usual interest, because they expand the ideas which have heretofore been held respecting the application of agricultural chemistry. To many people agricultural chemistry means solely the analyses of soils and fertilizers, whereas in its broadest sense it covers the study of the composition of plants and animals and the foods which produce them. Agricultural chemistry in this sense becomes one of the most important of the biological sciences, and as such is now recognized by those who fully understand its scope and its possibilities.

H. W. WILEY, Chief of Bureau. 


\section{CONTENTS.}

$\begin{array}{ll} & \text { Page. } \\ & \end{array}$

Arrangements for collaboration........................... 11

Preliminary experiment on the effect of storage on sugar content........ 12

Methods of analysis...................................... 14

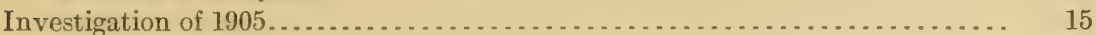

South Carolina................................................ 15

Maryland............................................ 16

New Jersey......................................... 18

Connecticut........................................ 19

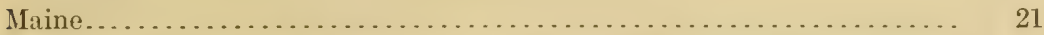

Influence of ripeness on sugar content as judged by taste and by chemical

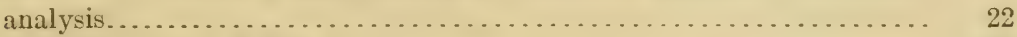

General discussion of data................................. 23

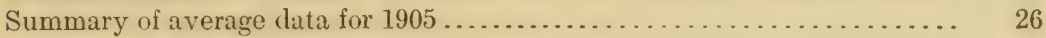

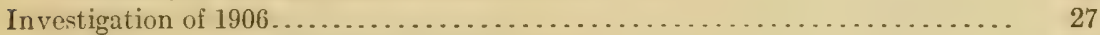

Changes in the organization of the work ........................ 27

Methods of planting and sampling ......................... 27

Florida............................................ 28

South Carolina........................................... 30

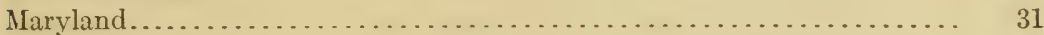

Connecticut............................................. 33

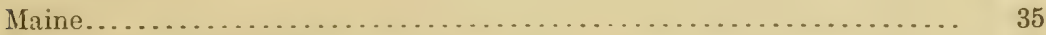

General discussion of data................................ 36

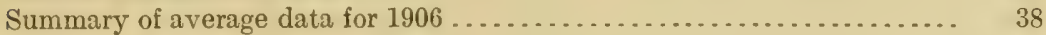

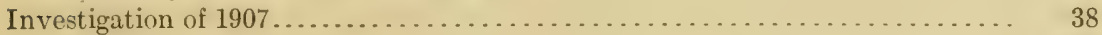

Introduction........................................ 38

Florida.............................................. 38

South Carolina.......................................... 40

Maryland................................................. 42

Connecticut........................................... 43

Maine............................................... 45

General discussion of data............................... 46

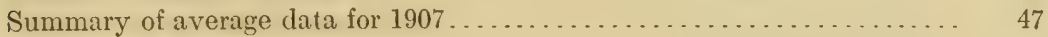

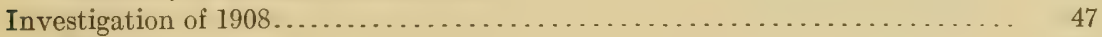

Florida........................................... 47

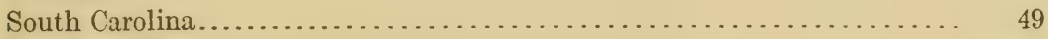

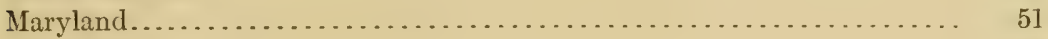

Connecticut............................................. 52

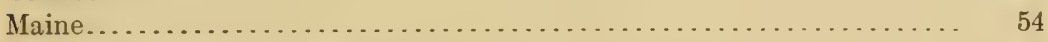

General discussion of data................................ 55

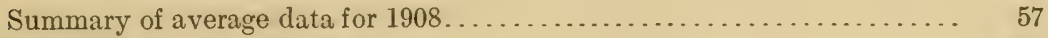

Summary of the four years' work ............................. 57

General discussion......................................... 57

Distribution of rainfall.................................... 62

General conclusions ..................................... 68 


\section{ILLUSTRATIONS.}

FiG. 1. Percentage of sugar in the corn, temperature, altitude, and average length of day at the different stations, $1905 . \ldots \ldots \ldots \ldots \ldots \ldots$.

2. Percentage of sugar in the corn, temperature, altitude, and average length of day at the different stations, $1906 . . . . . . . . . . . . . .$.

3. Percentage of sugar in the corn, temperature, altitude, and average length of day at the different stations, $1907 . \ldots . . . . . . . . . .$.

4. Percentage of sugar in the corn, temperature, altitude, and average length of day at the different stations, $1908 . . . \ldots . . . . . . . . .$.

5. Four years' summary. Percentage of sugar in the corn, temperature, average length of day, and altitude at the different stations.........

6. Four years' summary. Average percentage of sugar in the corn, sunshine record, rainfall, and latitude of the station.................

7. Daily distribution of rainfall by periods for 1906, 1907, and 1908 at the

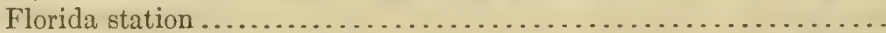

8. Daily distribution of rainfall by periods for 1906,1907 , and 1908 at the

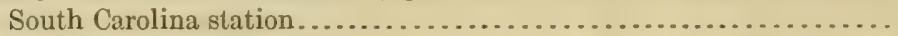

9. Daily distribution of rainfall by periods for 1906,1907 , and 1908 at the Maryland station.

Page.

10. Daily distribution of rainfall by periods for 1906, 1907, and 1908 at the Connecticut station .

11. Daily distribution of rainfall by periods for 1906 and 1908 at the Maine station. 


\section{THE INFLUENCE OF ENVIRONIENT ON THE COMPOSI- TION OF SWEET CORN, 1905-1908.}

\section{ORGANIZATION OF THE WORK.}

ARRANGEMENTS FOR COLLABORATION.

In beginning the investigation of the effect of environment on the composition of sweet corn, the experiment stations of South Carolina, Maryland, New Jersey, Connecticut, and Maine were asked to cooperate, the following letters being sent to the directors of these stations:

March 20, 1905.

DeAR SIR: I have requested the Secretary to authorize this Bureau to study the effect of environment upon the chemical composition of sugar corn, following the method pursued in the past five years in connection with the problem of the sugar beet. To this end we desire to have a small plat of sugar corn of uniform quality planted at several agricultural experiment stations. The plat should not exceed one-twentieth of an acre in area. The ordinary careful attention to the preparation of the land and to the planting and cultivation will be expected to be given by the station. At the proper time, when the corn is in the green state fit for consumption, some samples should be harvested, packed under the directions to be furnished by this Bureau, and mailed under frank for analysis. The work will not be onerous and will be very valuable. We shall expect also a transcription of the meteorological observations for this station every month. * * *

Having received favorable replies from all of the stations mentioned, the following letter, together with the sample of corn to be planted, was sent:

DEAR SIR: In harmony with your agreement to cultivate a plat of sugar corn I am sending you under separate cover 4 pounds of sugar-corn seed, "Stowell Evergreen," grown in Connecticut. This is a part of the seed which will be planted at various stations. I do not think it necessary to offer any suggestions in regard to the character of the soil or the method of cultivation which you may practice. The conditions under which the work is conducted will determine for each place the character of cultivation, etc. I suggest that you make a record of fieldwork as follows:

1. Character of the soil.

2. Previous history and cultivation as far as known.

3. Kind of crop last grown and character of fertilization.

4. Depth of plowing and method of preparing seed bed.

5. Date of planting.

6. Date on which the young plants come up.

7. Character and kind of fertilization.

8. Frequency and manner of cultivation.

9. Date of tasseling.

10. Date at which corn reaches maturity, suitable for table use. 
11. Date of complete ripening and hardening of the corn.

12. Date of first frost, if any.

13. Date of harvesting of ripened corn.

14. Yield in stalks and ears per acre.

15. Meteorological data, including time and amount of rainfall, average temperature, etc.

In regard to the sampling for analytical work, subsequent communication will be made, and to this end I shall be glad to have you inform me about the time when the corn will be ready for table use. Further suggestions will be then made, and probably an agent of this Bureau will be present to assist in the sampling. ***

After sending the sample of Stowell Evergreen it was decided that it would be advisable to use also a corn that ripened earlier, owing to the improbability that the variety named would ripen in Maine, and the following letter, together with a sample of Crosby corn, was sent to the various stations cooperating:

APRIL 19, 1905.

DEAR SrR: It seems quite probable that the sample of sweet-corn seed which I sent you-Stowell Evergreen-will not ripen at the northern stations which are cooperating in the experimental work. I ask, therefore, that you plant also a small plat of Crosby corn which I am sending herewith, as this will certainly ripen even as far north as Maine. I desire, also, to add a word of caution which probably is wholly unnecessary, since you doubtless would have avoided any danger of contamination anyway. Do not plant the varieties of sweet corn near other varieties, especially of field corn, where there can be any danger of mixing the pollen. Only a small area will be necessary of this second variety; perhaps one thirty-secondth of an acre will be entirely suffcient. I am sending you about 2 or 3 pounds of the seed.

I am informed by those in charge of the seed distribution here that the vitality of this Crosby corn is not very high, only about 70 per cent. I therefore suggest that you plant the seed liberally and then thin down to the proper number of stalks. * * *

\section{PRELIMINARY EXPERIMENT ON TIIE EFFECT OF STORAGE ON SUGAR CONTENT.}

It was the original intention to have an agent of the Bureau of Chemistry visit the various stations when the corn was ripe, harvest the necessary amount and, without husking, wrap the ears carefully in oiled paper to prevent evaporation of water, and ship the samples directly to the Bureau at Washington. Prior to the ripening of the corn in South Carolina, samples of green corn were secured on the open market, and a study of the effect of storage at room temperatures, such as would be encountered in shipping, was made.

The sugars were determined in a number of the ears and the remaining ones were moistened, wrapped in oiled paper, weighed, and stored at room temperature for thirty-six hours. At the expiration of this time they were again weighed and the amount of sugars determined. Only a slight loss in weight was observed, as shown by the following table, but the sugars showed a marked decrease. On opening the stored samples they were found to be sweet, and no trace of fermentation could be perceived. 
Effect on green corn of thirty-six hours' storage at room temperature.

(June 21 to June 23, 1905.)

\begin{tabular}{|c|c|c|c|}
\hline \multicolumn{2}{|c|}{ Weight. } & \multicolumn{2}{|c|}{ Sugar. } \\
\hline $\begin{array}{l}\text { Before } \\
\text { storage. }\end{array}$ & $\begin{array}{c}\text { After } \\
\text { storage. }\end{array}$ & $\begin{array}{c}\text { Before } \\
\text { storage. }\end{array}$ & $\begin{array}{c}\text { After } \\
\text { storage. }\end{array}$ \\
\hline $\begin{array}{r}\text { Grams. } \\
239 \\
237 \\
236 \\
225 \\
231 \\
251\end{array}$ & $\begin{array}{r}\text { Grams. } \\
236 \\
235 \\
233 \\
223 \\
226 \\
244\end{array}$ & $\begin{array}{r}\text { Per cent. } \\
1.70 \\
1.71 \\
1.68 \\
1.49 \\
\ldots . . . . .\end{array}$ & $\begin{array}{r}\text { Per cent. } \\
0.95 \\
1.70 \\
1.11 \\
a .47\end{array}$ \\
\hline
\end{tabular}

a Sample had a sour odor.

Attention is called to the fact that these analyses were made on corn (Adams Early) bought on the market, and which hacl rery probably been pulled for a day or more before the work was begun. This might account for the low percentage of sugars found before storage. More extended studies on this point made at the Maryland station on a large number of samples verify the tendency here indicated for the corn to decrease in sugar content during storage.

In connection with the problem of shipping the corn from the various stations for analysis, and also because of the interest of the matter to canners, a further study was made as to the effect of storage at various temperatures and under various conditions; that is, husked and unhusked, and wrapped in oiled paper. The detailed results of this study have been reported by the Maryland station, in cooperation with which station the work was done. ${ }^{a}$ The temperatures varied from the normal room temperature of $77^{\circ} \mathrm{F} .\left(25^{\circ} \mathrm{C}\right.$.) to refrigerator temperature, $63^{\circ} \mathrm{F}$. $\left(17^{\circ} \mathrm{C}\right.$.).

In the freshly pulled samples the sugars present were 4.59 and 4.74 per cent. On standing twenty-four hours at room temperature, unhusked, about one-third of the sugars disappeared; after the next twenty-four hours another loss was noticed, but when the sugars reached 1.80 per cent no further decrease took place. The taste was not so good after twenty-four hours as when the sample was first pulled. As the time of storage increased, the flavor deteriorated, and after ninety-six hours the corn tasted flat and sour and the kernels were wrinkled. The data do not show that any material difference resulted from husking the ear, wrapping it in oiled paper, or storing it in the refrigerator. This is true both of the taste and the percentage of sugars found. The work shows that corn should not be pulled until ready for use, and should be put on the market or canned with as little delay as possible after gathering.

a Maryland Agr. Exper. Sta., Bul. 120, Sweet Corn Investigations, 1907. 
Owing to the location of some of the cooperating stations, from twenty-four to thirty-six hours would elapse between the time the samples were picked and their arrival at the Bureau; and if they came in the afternoon, sixteen hours more would elapse before work on them could be begun. The decrease in the sugar content in transition from the field to the laboratory, as shown by the work just reviewed, would, of course, give misleading results and defeat the object of the investigation; therefore another plan had to be devised. The most feasible one seemed to be to have the chemist visit each laboratory at the time the corn was ready for harvesting and make the analyses there. Accordingly analytical work was begun at the South Carolina station about July 10, 1905.

The sugar determinations were all made by reduction of alkaline copper sulphate weighed as copper suboxid and calculated from this to sugars by means of the Munson-Walker tables. ${ }^{a}$ To this end, enough Fehling solution, as modified by Soxhlet, was made to complete the determinations at all of the stations, and this, together with the graduated glassware and weights, was sent to the various stations in order to insure uniformity.

The method employed was one devised at the Maryland experiment station for use on dried corn and was found to be satisfactory for green sweet corn. In brief it was as follows:

Remove a sample of the corn, equal to about three rows of kernels, pass through a food cutter, then pound in a mortar to break up the germs. Wash 16 grams of this macerated sample into a 200-cc flask with a 40-per cent boiling alcohol solution; place this on a hot water bath and boil gently for one hour; cool, make up to mark with 95 per cent alcohol, shake thoroughly, and allow to settle. Draw out 50 ce (4 grams of original sample) of the solution, add about 50 cc of water, and drive off the alcohol carefully. Wash the dealcoholized solution into a 100-cc flask; add a sufficient quantity of neutral lead acetate ${ }^{b}$ precipitate the lead with sodium carbonate; make up to the mark with distilled water, shake, filter, and take 50 cc for inversion according to Clerget's method. The reduction was then accomplished by means of the Soxhlet method as outlined in Bulletin 107, Revised, of the Bureau of Chemistry, page 43, with the exception that recently-boiled distilled water was not added at the end of the reduction.

$a$ U. S. Dept. Agr., Bureau of Chemistry, Bul. 107, Rev., p. 243.

$\checkmark$ In dry corn it is necessary to add alumina cream also. 


\section{INVESTIGATION OF 1905.}

\section{SOUTH CAROLINA.}

At the South Carolina station the Crosby corn was grown in a field of sandy loam which was cleared in 1891 and rotated in corn, cotton, cowpeas, oats, and cowpeas. The last crop of oats followed by cowpeas was grown in 1904 with a fertilization of 600 pounds per acre of equal parts of acid phosphate, cotton-seed meal, and kainit.

In 1905 the ground was plowed to a depth of 8 inches, furrows opened 4 feet apart, fertilizer applied and mixed with the soil, and the seed planted $\Lambda$ pril 24, and covered with a plow. The fertilizer for this crop was made up of 200 pounds of 14 per cent acid phosphate, 200 pounds of cotton-seed meal, and 200 pounds of kainit per acre. A weeder was used April 28 and May 1 and the plants came up May 5. The plat was worked May 9 and 20 and June 12. The corn tasseled June 14, and a few ears were ready for table use June 28.

The meteorological data furnished for Clemson College for the growing season in 1905 are as follows:

Meterological data for Clemson College, S. C., 1905.

\begin{tabular}{|c|c|c|c|c|c|}
\hline Month. & $\begin{array}{l}\text { Mean } \\
\text { temper- } \\
\text { ature. }\end{array}$ & $\begin{array}{l}\text { Precipi- } \\
\text { tation. }\end{array}$ & $\begin{array}{l}\text { Clear } \\
\text { days. }\end{array}$ & $\begin{array}{l}\text { Partly } \\
\text { cloudy } \\
\text { days. }\end{array}$ & $\begin{array}{l}\text { Cloudy } \\
\text { days. }\end{array}$ \\
\hline $\begin{array}{l}\text { April.. } \\
\text { May... } \\
\text { June... } \\
\text { July... }\end{array}$ & $\begin{array}{l}{ }^{\circ} F . \\
62.0 \\
72.2 \\
77.5 \\
79.2\end{array}$ & $\begin{array}{r}\text { Inches. } \\
2.79 \\
8.65 \\
1.07 \\
7.29\end{array}$ & $\begin{array}{l}18 \\
20 \\
20 \\
22\end{array}$ & $\begin{array}{l}4 \\
3 \\
7 \\
7\end{array}$ & $\begin{array}{l}8 \\
8 \\
3 \\
2\end{array}$ \\
\hline
\end{tabular}

Analysis of individual ears of Crosby corn grown at Clemson College, S. C., 1905.

\begin{tabular}{|c|c|c|c|}
\hline Serial No. & Moisture. & $\begin{array}{c}\text { Total } \\
\text { sugars. }\end{array}$ & $\begin{array}{c}\text { Sugars } \\
\text { calcu- } \\
\text { lated to } \\
\text { water- } \\
\text { free basis }\end{array}$ \\
\hline $\begin{array}{l}235 \ldots \ldots \\
233 \ldots \ldots \\
230 \ldots \\
237 \ldots \ldots \\
234 \ldots \\
231 \ldots \\
238 \ldots \\
232 \ldots \\
236 \ldots \\
\ldots \\
\ldots\end{array}$ & $\begin{array}{r}\text { Per cent. } \\
68.80 \\
68.38 \\
68.86 \\
67.30 \\
63.35 \\
62.06 \\
66.55 \\
65.55 \\
61.70\end{array}$ & $\begin{array}{r}\text { Per cent. } \\
13.55 \\
13.18 \\
12.76 \\
12.23 \\
12.46 \\
12.86 \\
10.55 \\
10.65 \\
11.74\end{array}$ & $\begin{array}{c}\text { Per cent. } \\
43.42 \\
41.68 \\
40.97 \\
37.40 \\
33.99 \\
33.90 \\
31.54 \\
30.92 \\
30.66\end{array}$ \\
\hline $\begin{array}{l}\text { Maximum... } \\
\text { Minimum ... } \\
\text { Average.... }\end{array}$ & $\begin{array}{l}68.80 \\
61.70 \\
65.84\end{array}$ & $\begin{array}{l}13.55 \\
10.55 \\
12.22\end{array}$ & $\begin{array}{l}43.42 \\
30.66 \\
36.05\end{array}$ \\
\hline
\end{tabular}

The Stowell Evergreen was grown on a field of sandy loam on which corn had been raised in 1900 and 1901, artichokes in 1902 and 1904, and soy beans in 1903. The fertilizer used in 1904 consisted of 100 pounds of acid phosphate, 100 pounds of cotton-seed meal, and 100 pounds of kainit per acre. For the 1905 crop, 2,000 pounds of composite per acre were used, consisting of 1,000 pounds of stable manure, 600 pounds of cotton-seed meal, and 400 pounds of 14 per 
cent acid phosphate. The ground was plowed 4 inches deep and flushed. The seed was planted April 12, and the plants appeared sixteen days later, April 28. A weeder was then used, and the ground was gone over with a scraper May 1, 10, and 17. On June 15 the corn tasseled and was ready for the table about July 8 .

The average analysis of the corn grown at the South Carolina experiment station shows that the moisture content of the Crosby is not nearly so high as that of the Stowell, while the sugar content is nearly double, and when calculated to a water-free basis the total sugars are still very much higher, indicating a more palatable product. The Crosby corn was ready for table use about ten days earlier than the Stowell, early ripening constituting another characteristic advan. tage of that variety.

Analysis of individual ears of Stowell Evergreen corn groun at Clemson College, S. C., 1905.

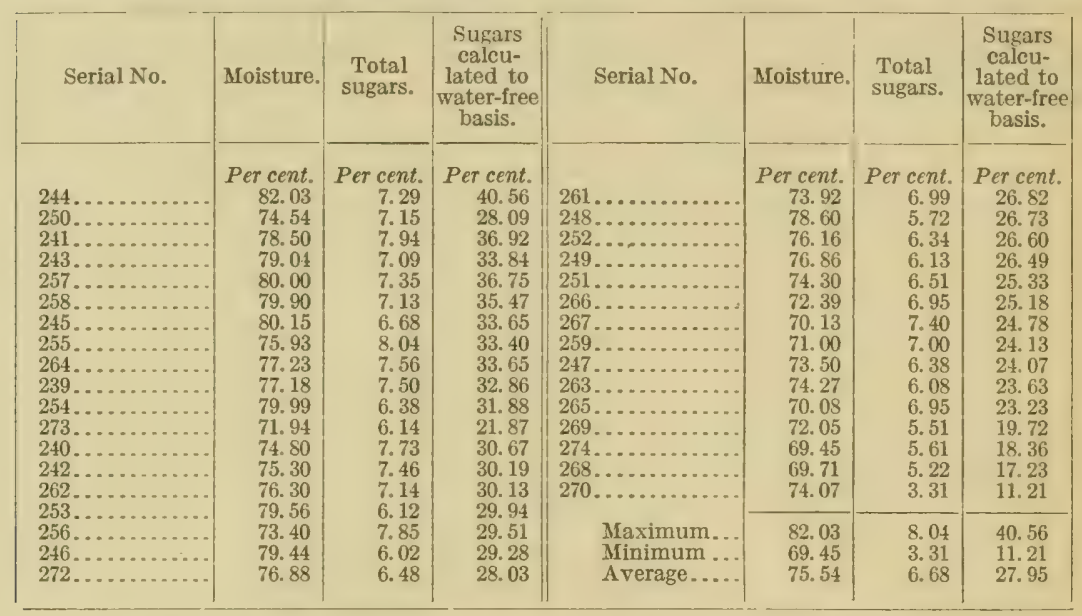

Comparison by weight of the various parts to the whole ear (Stowell Evergreen).

\begin{tabular}{|c|c|c|c|c|c|c|}
\hline Serial No. & $\begin{array}{l}\text { Weight of } \\
\text { entire ear. }\end{array}$ & \multicolumn{2}{|c|}{ Weight of husk. } & \multicolumn{2}{|c|}{ Weight of kernels. } & \multirow{2}{*}{$\begin{array}{r}\text { Weight } \\
\text { of cob. }\end{array}$} \\
\hline $\begin{array}{l}270 . \\
271 \\
272 \\
273 . \\
274 . \\
275 .\end{array}$ & $\begin{array}{c}\text { Grams. } \\
440 \\
465 \\
450 \\
406 \\
347 \\
325\end{array}$ & $\begin{array}{r}\text { Grams. } \\
161 \\
125 \\
210 \\
103 \\
87 \\
108\end{array}$ & $\begin{array}{r}\text { Per cent. } \\
36.6 \\
26.9 \\
46.7 \\
25.3 \\
25.1 \\
33.2\end{array}$ & $\begin{array}{r}\text { Grams. } \\
164 \\
205 \\
120 \\
172 \\
145 \\
147\end{array}$ & $\begin{array}{r}\text { Per cent. } \\
37.3 \\
44.1 \\
26.7 \\
42.3 \\
41.8 \\
43.7\end{array}$ & \\
\hline Average & 405.5 & 132 & 32.3 & 158 & 39.3 & 114 \\
\hline
\end{tabular}

\section{MARYLAND.}

The field set apart for the sugar-corn work at the Maryland station was a plat of clay loam which had not been tilled for the last fifteen years. It was plowed about 6 inches deep, harrowed twice, and a float was used to break up the clods. No fertilizer was used, and the corn was planted April 28. On May 24 and on June 6 and 26 the field was worked with a tooth cultivator, and on June 21 it was hoed. 
The first corn ready for table use ripened about the first week in August, and the matured corn was harrested October 1. These data apply equally to the Crosby and to the Stowell Evergreen, except that the Crosby matured a week earlier than the Stowell.

The climatic conditions under which this corn was grown and the analytical data obtained are shown in the following tables:

Meteorological data for College Park, Mdd., 1905.

\begin{tabular}{|c|c|c|c|c|c|}
\hline Month. & $\begin{array}{l}\text { Mean } \\
\text { temper- } \\
\text { ature. }\end{array}$ & $\begin{array}{c}\text { Precipi- } \\
\text { tation. }\end{array}$ & $\begin{array}{l}\text { Clear } \\
\text { days. }\end{array}$ & $\begin{array}{l}\text { Cloudy } \\
\text { days. }\end{array}$ & $\begin{array}{l}\text { Num- } \\
\text { ber of } \\
\text { rains. }\end{array}$ \\
\hline $\begin{array}{l}\text { April ........... } \\
\text { May ............ } \\
\text { June . . . . . . } \\
\text { July ........... } \\
\text { August......... }\end{array}$ & $\begin{array}{r}{ }^{\circ} F . \\
55.8 \\
63.8 \\
69.8 \\
76.6 \\
74.0\end{array}$ & $\begin{array}{r}\text { Inches. } \\
2.75 \\
3.14 \\
3.77 \\
6.97 \\
7.86\end{array}$ & $\begin{array}{l}20 \\
25 \\
21 \\
19 \\
19\end{array}$ & $\begin{array}{r}6 \\
5 \\
5 \\
4 \\
11\end{array}$ & $\begin{array}{l}5 \\
4 \\
7 \\
9 \\
7\end{array}$ \\
\hline
\end{tabular}

Analysis of individual ears of Stowell Evergreen corn groun at College Park, IId., 1905.

\begin{tabular}{|c|c|c|c|c|c|c|c|}
\hline Serial No. & Moisture. & $\begin{array}{l}\text { Total } \\
\text { sugars. }\end{array}$ & $\begin{array}{c}\text { Sugars } \\
\text { calcu- } \\
\text { lated to } \\
\text { water-free } \\
\text { basis. }\end{array}$ & Serial No. & Moisture. & $\begin{array}{c}\text { Total } \\
\text { sugars. }\end{array}$ & $\begin{array}{c}\text { Sugars } \\
\text { calcu- } \\
\text { lated to } \\
\text { water-free } \\
\text { basis. }\end{array}$ \\
\hline 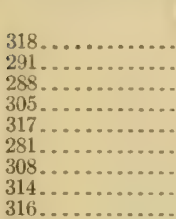 & $\begin{array}{r}\text { Per cent. } \\
82.71 \\
79.00 \\
81.09 \\
80.60 \\
82.08 \\
80.39 \\
81.03 \\
84.28 \\
79.24\end{array}$ & $\begin{array}{r}\text { Per cent. } \\
6.83 \\
7.62 \\
6.80 \\
6.52 \\
5.96 \\
6.44 \\
6.19 \\
5.00 \\
5.82\end{array}$ & $\begin{array}{r}\text { Per cent. } \\
39.50 \\
36.28 \\
35.96 \\
33.61 \\
33.27 \\
32.84 \\
32.63 \\
31.81 \\
28.03\end{array}$ & $\begin{array}{l}282 \ldots \ldots \ldots \ldots \\
290 \ldots \ldots \ldots \\
283 \ldots \ldots \ldots \\
311 \ldots \ldots \ldots \\
289 \ldots \ldots \ldots \\
319 \ldots \ldots \ldots \\
321 \ldots \ldots \ldots \\
313 \ldots \ldots \ldots\end{array}$ & $\begin{array}{r}\text { Per cent. } \\
75.65 \\
70.67 \\
78.32 \\
78.35 \\
71.97 \\
74.86 \\
73.45 \\
78.98\end{array}$ & \begin{tabular}{r|} 
Per cent. \\
5.52 \\
6.29 \\
4.80 \\
4.53 \\
5.80 \\
4.98 \\
5.26 \\
3.97
\end{tabular} & $\begin{array}{c}\text { Per cent. } \\
22.66 \\
21.45 \\
22.14 \\
20.92 \\
20.69 \\
19.81 \\
19.81 \\
18.89\end{array}$ \\
\hline $\begin{array}{l}312 \ldots \ldots \ldots \\
280 \ldots \ldots \ldots \\
315 \ldots \ldots \ldots \\
307 \ldots \ldots \ldots\end{array}$ & $\begin{array}{l}76.65 \\
77.30 \\
78.68 \\
75.31\end{array}$ & $\begin{array}{l}6.23 \\
5.67 \\
5.26 \\
5.93\end{array}$ & $\begin{array}{l}26.68 \\
24.97 \\
24.67 \\
24.04\end{array}$ & $\begin{array}{l}\text { Maximum... } \\
\text { Minimum ... } \\
\text { Average.... }\end{array}$ & $\begin{array}{l}81.28 \\
70.67 \\
78.13\end{array}$ & $\begin{array}{l}\text { 7. } 62 \\
\text { 3. } 97 \\
5.78\end{array}$ & $\begin{array}{l}39.50 \\
18.89 \\
27.18\end{array}$ \\
\hline
\end{tabular}

Comparison by weight of various parts to the whole ear (Stowell Evergreen).

\begin{tabular}{|c|c|c|c|c|c|c|}
\hline Serial No. & $\begin{array}{l}\text { Weight of } \\
\text { entire ear. }\end{array}$ & \multicolumn{2}{|c|}{ Weight of husk. } & \multicolumn{2}{|c|}{ Weight of kernels. } & $\begin{array}{c}\text { Weight of } \\
\text { cob. }\end{array}$ \\
\hline $\begin{array}{l}307 \ldots \ldots \\
313 \ldots \ldots \\
305 \ldots \ldots \\
289 \ldots \ldots \\
283 \ldots \ldots \\
306 \ldots \ldots \\
282 \ldots \ldots \\
288 \ldots \\
312 \ldots \ldots \\
308 \ldots \ldots \\
280 \ldots \ldots \\
311 \ldots \ldots \\
315 \ldots \ldots \\
281 \ldots \ldots \\
291 \ldots \ldots \\
290 \ldots \ldots \\
314 \ldots \ldots \\
\end{array}$ & $\begin{array}{r}\text { Grams. } \\
565 \\
519 \\
495 \\
475 \\
447 \\
445 \\
445 \\
430 \\
427 \\
408 \\
395 \\
368 \\
363 \\
350 \\
330 \\
325 \\
285\end{array}$ & $\begin{array}{r}\text { Grams. } \\
133 \\
129 \\
120 \\
185 \\
187 \\
115 \\
145 \\
195 \\
135 \\
121 \\
115 \\
103 \\
88 \\
140 \\
124 \\
89 \\
73\end{array}$ & $\begin{array}{r}\text { Per cent. } \\
23.54 \\
24.86 \\
24.24 \\
38.95 \\
41.84 \\
25.84 \\
32.58 \\
45.35 \\
31.62 \\
29.66 \\
29.11 \\
27.99 \\
24.24 \\
40.00 \\
37.58 \\
27.38 \\
25.61\end{array}$ & $\begin{array}{r}\text { Grams. } \\
267 \\
210 \\
210 \\
150 \\
130 \\
195 \\
180 \\
107 \\
150 \\
142 \\
155 \\
130 \\
147 \\
95 \\
96 \\
136 \\
87\end{array}$ & $\begin{array}{r}\text { Per cent. } \\
47.26 \\
40.46 \\
42.42 \\
31.58 \\
29.08 \\
43.82 \\
40.45 \\
24.88 \\
35.15 \\
34.80 \\
39.24 \\
35.33 \\
40.50 \\
27.14 \\
29.09 \\
41.85 \\
30.53\end{array}$ & $\begin{array}{r}\text { Grams. } \\
165 \\
180 \\
165 \\
140 \\
130 \\
136 \\
120 \\
128 \\
142 \\
145 \\
125 \\
135 \\
128 \\
115 \\
110 \\
100 \\
125\end{array}$ \\
\hline A verage. & 416 & 129 & 31.01 & 152 & 36.54 & 135 \\
\hline
\end{tabular}

The meteorological data show a normal rainfall for April, May, and June, but for the months of July and August, when the ears were forming, the precipitation was excessive, the average for these months 4925-Bull. $127-09-2$ 
for a period of twenty-six years being 4.7 and 4 inches, respectively. The number of clear days was not so great during July and August as for the previous months.

A very poor crop of the Crosby corn was secured. Aside from the low vitality, the wire worm destroyed a large percentage of the young plants, and no analyses were made of this variety. The Stowell Evergreen showed more variation here than in South Carolina. The plants were much larger and stronger and the yield considerably greater. In South Carolina the ears were much injured by worms, while in Maryland very little trouble from this cause was experienced.

\section{NEW JERSEY.}

The soil on which the corn was grown at the New Jersey station was a light, gravelly loam on which a crop of corn had been grown in 1904. In preparing the ground it was plowed and harrowed, and the seed was planted May 10. At intervals of about ten days it was cultivated and hoed, and the green corn was ready for table use about September 6 . The yield was only half a crop, and the matured corn was harvested October 15. Tables showing the meteorological and analytical data for the season follow:

Meteorological data for, New Brunswick, N. J., 1905.

\begin{tabular}{|r|r|r|r|r|r|r|}
\hline Month. & $\begin{array}{c}\text { Mean } \\
\text { temper- } \\
\text { ature. }\end{array}$ & $\begin{array}{c}\text { Precipi- } \\
\text { tation. }\end{array}$ & $\begin{array}{c}\text { Clear } \\
\text { days. }\end{array}$ & $\begin{array}{c}\text { Partly } \\
\text { cloudy. }\end{array}$ & $\begin{array}{c}\text { Cloudy } \\
\text { days. }\end{array}$ & $\begin{array}{c}\text { Num- } \\
\text { ber of } \\
\text { rains. }\end{array}$ \\
\hline & 0.7. & Inches. & & & & \\
May........... & 61.2 & 1.83 & 17 & 8 & 6 & 7 \\
June........... & 68.3 & 1.83 & 15 & 11 & 4 & 7 \\
July........... & 74.6 & 4.23 & 17 & 13 & 1 & 5 \\
September...... & 70.9 & 4.96 & 19 & 6 & 6 & 6 \\
\hline
\end{tabular}

Analysis of individual cars of Stowell Evergreen corn groun at New Brunswick, N. J., 1905.

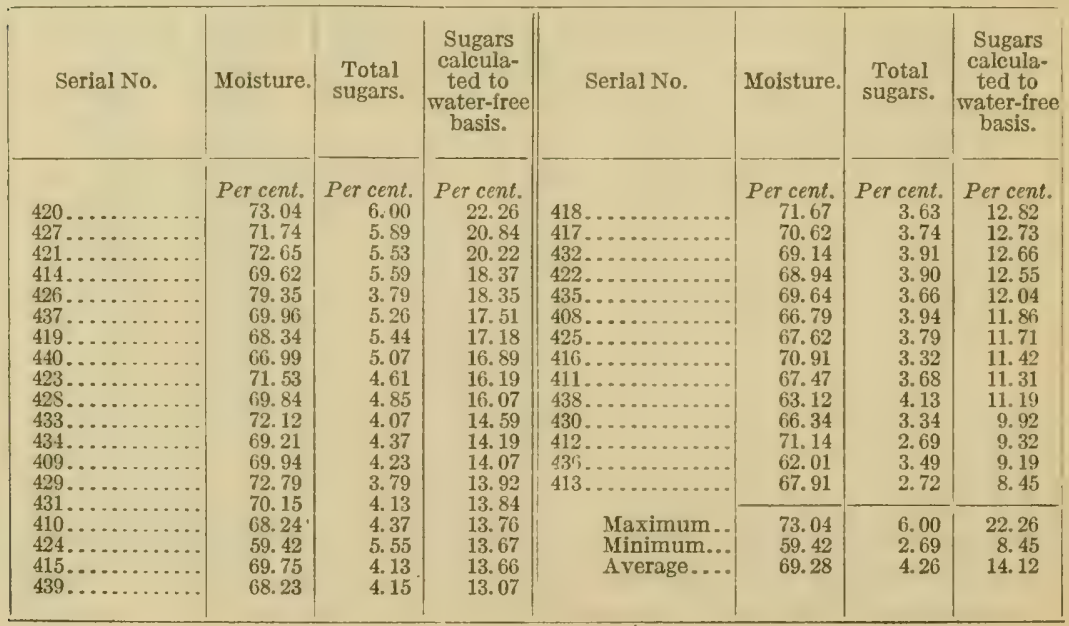


Comparison of weight of ear and various parts (Stowell Evergreen).

\begin{tabular}{|c|c|c|c|c|c|c|}
\hline Serial No. & $\begin{array}{c}\text { Weight } \\
\text { of entire } \\
\text { ear. }\end{array}$ & \multicolumn{2}{|c|}{ Weight of husk. } & \multicolumn{2}{|c|}{ Weight of kernels. } & \multirow{2}{*}{$\begin{array}{r}\text { Weight } \\
\text { of cob. } \\
\text { Grams. } \\
118 \\
144 \\
134 \\
103 \\
71 \\
90 \\
107\end{array}$} \\
\hline $\begin{array}{l}369 \ldots \ldots \\
377 \ldots \ldots \\
367 \ldots \ldots \\
368 \ldots \\
370 \ldots \ldots \\
371 \ldots \ldots \\
378 \ldots \ldots\end{array}$ & $\begin{array}{r}\text { Grams. } \\
445 \\
425 \\
407 \\
404 \\
338 \\
335 \\
310\end{array}$ & $\begin{array}{r}\text { Grams. } \\
160 \\
129 \\
142 \\
149 \\
76 \\
120 \\
112\end{array}$ & $\begin{array}{r}\text { Per cent. } \\
35.96 \\
30.35 \\
34.89 \\
36.88 \\
22.49 \\
35.82 \\
36.13\end{array}$ & $\begin{array}{r}\text { Grams. } \\
177 \\
152 \\
131 \\
152 \\
191 \\
125 \\
91\end{array}$ & $\begin{array}{r}\text { Per cent. } \\
39.77 \\
35.76 \\
32.18 \\
37.62 \\
56.51 \\
37.31 \\
29.35\end{array}$ & \\
\hline Average...... & 381 & 126 & 33.11 & 146 & 38.26 & 110 \\
\hline
\end{tabular}

The meteorological data show a dry period during the principal growing months, but an abundant rainfall during the period of maturing, the total precipitation being nearly 20 per cent below the average. Mr. Halstead, of the New Jersey station, has called attention to the fact that the summer season was quite unusual, the drought being so severe that the corn crop on the station farm was reduced fully one-half and practically no corn of the Crosby variety matured. The Stowell Evergreen did not reach nearly the growth of stalks or ears in New Jersey that it did in Maryland or Connecticut, and the sugar content was much lower than at any other station.

\section{CONNECTICUT.}

About one-twentieth of an acre on the Connecticut station grounds was devoted to the experimental sweet corn. The soil is a light, sandy loam and had been used previously for garden vegetables. The plat was plowed, harrowed, and fertilized with stable manure. The seed was planted May 12, and the field was kept entirely free from weeds by the use of a horse cultivator supplemented by hand hoeing. The corn was ready for table use on August 24.

The climatic conditions existing at New Haven are shown by the following table:

Meteorological data for New Haven, Conn., 1905.

\begin{tabular}{|c|r|r|r|r|r|}
\hline Month. & $\begin{array}{c}\text { Mean } \\
\text { temper- } \\
\text { ature. }\end{array}$ & $\begin{array}{l}\text { Precipi- } \\
\text { tation. }\end{array}$ & $\begin{array}{c}\text { Clear } \\
\text { days. }\end{array}$ & $\begin{array}{c}\text { Cloudy } \\
\text { days. }\end{array}$ & $\begin{array}{r}\text { Num- } \\
\text { ber of } \\
\text { rains. }\end{array}$ \\
\hline & \multicolumn{1}{c}{${ }^{\circ}}$. & Inches. & & & \\
May.............. & 57.6 & 1.18 & 11 & 9 & 8 \\
June............ & 65.5 & 5.87 & 9 & 8 & 11 \\
July ........... & 73.0 & 2.86 & 15 & 5 & 11 \\
August........ & 68.5 & 7.20 & 10 & 10 & 11 \\
\hline
\end{tabular}


The precipitation was not very evenly distributed, being low in May, when the corn was planted, and excessive during the early growing stages and the maturing period.

Analysis of individual ears of Crosby corn grown at New Haven, Conn., 1905.

\begin{tabular}{|c|c|c|c|}
\hline Serial No. & Moisture. & $\begin{array}{c}\text { Total } \\
\text { sugars. }\end{array}$ & $\begin{array}{l}\text { Sugars cal- } \\
\text { culated to } \\
\text { water-free } \\
\text { basis. }\end{array}$ \\
\hline $\begin{array}{l}373 \ldots \ldots \\
372, \ldots \ldots \\
366, \ldots \\
375 \ldots \\
365, \ldots \ldots \\
364 \ldots \\
374 \ldots \ldots \\
\end{array}$ & $\begin{array}{r}\text { Per cent. } \\
81.01 \\
76.51 \\
76.33 \\
71.50 \\
75.10 \\
62.44 \\
68.23\end{array}$ & $\begin{array}{r}\text { Per cent. } \\
9.44 \\
9.14 \\
7.09 \\
8.20 \\
6.59 \\
7.42 \\
6.21\end{array}$ & $\begin{array}{r}\text { Per cent. } \\
49.71 \\
38.90 \\
29.97 \\
28.77 \\
26.47 \\
19.75 \\
19.54\end{array}$ \\
\hline $\begin{array}{l}\text { Maximum.. } \\
\text { Minimum.. } \\
\text { Average... }\end{array}$ & $\begin{array}{l}81.01 \\
62.44 \\
73.01\end{array}$ & $\begin{array}{l}9.44 \\
6.21 \\
7.73\end{array}$ & $\begin{array}{l}49.71 \\
19.54 \\
30.44\end{array}$ \\
\hline
\end{tabular}

Analysis of individual ears of Stowell Evergren corn groun at New Haven, Conn., 1905.

\begin{tabular}{|c|c|c|c|c|c|c|c|}
\hline Serial No. & Moisture. & $\begin{array}{c}\text { Total } \\
\text { sugars. }\end{array}$ & $\begin{array}{c}\text { Sugars } \\
\text { calcula- } \\
\text { ted to } \\
\text { water-free } \\
\text { basis. }\end{array}$ & Serial No. & Moisture. & $\begin{array}{c}\text { Total } \\
\text { sugars. }\end{array}$ & $\begin{array}{c}\text { Sugars } \\
\text { calcula- } \\
\text { ted to } \\
\text { water-free } \\
\text { basis. }\end{array}$ \\
\hline $\begin{array}{l}388 \ldots \ldots \\
368 \ldots \ldots \ldots \\
386 \ldots \ldots \\
402 \ldots \ldots \\
397 \ldots \ldots \\
385 \ldots \ldots \\
405 \ldots \ldots \\
380 \ldots \ldots \\
382 \ldots \ldots \\
371 \ldots \ldots \ldots \\
379 \ldots \ldots \\
394 \ldots \ldots \\
398 \ldots \ldots \\
400 \ldots \ldots \\
\ldots\end{array}$ & $\begin{array}{r}\text { Per cent. } \\
81.39 \\
82.27 \\
74.26 \\
80.93 \\
74.70 \\
78.09 \\
79.47 \\
80.10 \\
72.43 \\
78.43 \\
77.14 \\
71.49 \\
77.14 \\
71.23\end{array}$ & $\begin{array}{r}\text { Per cent. } \\
5.92 \\
5.42 \\
7.50 \\
5.28 \\
6.93 \\
5.95 \\
5.52 \\
5.18 \\
6.97 \\
5.41 \\
5.73 \\
6.69 \\
5.36 \\
6.45\end{array}$ & $\begin{array}{r}\text { Percent. } \\
31.81 \\
30.56 \\
29.14 \\
27.70 \\
27.39 \\
27.15 \\
26.89 \\
26.02 \\
25.28 \\
25.07 \\
25.06 \\
23.46 \\
23.44 \\
22.42\end{array}$ & 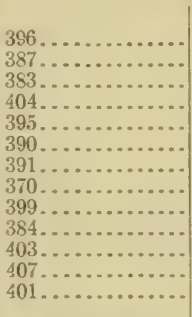 & $\begin{array}{r}\text { Per cent. } \\
70.26 \\
72.41 \\
73.09 \\
71.42 \\
76.35 \\
72.83 \\
69.54 \\
73.39 \\
69.44 \\
69.63 \\
74.90 \\
70.46 \\
70.18\end{array}$ & $\begin{array}{r}\text { Per cent. } \\
6.24 \\
5.59 \\
5.29 \\
5.41 \\
4.33 \\
4.76 \\
4.72 \\
4.03 \\
4.47 \\
4.41 \\
3.45 \\
4.00 \\
3.75\end{array}$ & $\begin{array}{c}\text { Percent. } \\
20.98 \\
20.26 \\
19.66 \\
18.93 \\
18.31 \\
17.51 \\
15.49 \\
15.14 \\
14.63 \\
14.52 \\
13.76 \\
13.54 \\
12.58\end{array}$ \\
\hline $\begin{array}{l}393 \ldots \ldots \\
406 \ldots \ldots \\
392 \ldots \ldots\end{array}$ & $\begin{array}{l}75.87 \\
71.18 \\
77.18 \\
75.91\end{array}$ & $\begin{array}{l}5.35 \\
6.22 \\
4.83 \\
5.09\end{array}$ & $\begin{array}{l}22.17 \\
21.57 \\
21.16 \\
21.12\end{array}$ & $\begin{array}{l}\text { Marimum. . } \\
\text { Minimum .. } \\
\text { Average... }\end{array}$ & $\begin{array}{l}82.27 \\
69.44 \\
74.62\end{array}$ & $\begin{array}{l}7.50 \\
3.45 \\
5.36\end{array}$ & $\begin{array}{l}31.81 \\
12.58 \\
21.70\end{array}$ \\
\hline
\end{tabular}

The average sugar content of the Crosby corn for 1905 was much above that for the Stowell Evergreen, but this was also true at each of the other stations. The general condition of the crop was better at Connecticut than at any other places, and no worms or weevils were present.

The moisture content of the Stowell Evergreen was rery near that for the South Carolina station, yet the sugar content was much lower, Connecticut standing third in percentage of sugars for this variety. 
MAINE.

The piece of land selected for the corn experiments at the Maine station was a plat of clay loam consisting of one-twentieth of an acre which had been used for garden vegetables. It was fertilized with a mixture containing 3 per cent of nitrogen, 6 per cent of phosphoric acid, and $\delta$ per cent of potash. The seeds were planted June 15, cultivated with a spike-tooth cultivator at intervals of ten days, and hoed as often as was necessary to keep the plat free from weeds. The green corn was ready for table use about September 15, and the mature corn was harvested October 14. The Stowell Evergreen failed to mature before a killing frost. That portion grown on land which had been devoted to cabbages the previous year was small and inferior. The rest was fair and typical of the rariety. Following are the tables of meteorological and analytical data:

Meteorological data for Orono, Me., 1905.

\begin{tabular}{|r|r|r|r|r|r|r|}
\hline Month & $\begin{array}{c}\text { Mean } \\
\text { tempera- } \\
\text { ture. }\end{array}$ & $\begin{array}{c}\text { Precipi- } \\
\text { tation. }\end{array}$ & $\begin{array}{c}\text { Clear } \\
\text { days. }\end{array}$ & $\begin{array}{c}\text { Cloudy } \\
\text { days. }\end{array}$ & $\begin{array}{c}\text { Fair } \\
\text { days. }\end{array}$ & $\begin{array}{c}\text { Num- } \\
\text { ber of } \\
\text { rains. }\end{array}$ \\
\hline & ${ }^{\circ}$ F. & Inches. & & & & \\
June........ & 60.6 & 3.13 & 10 & 17 & 3 & 7 \\
July....... & 68.6 & 2.19 & 10 & 6 & 15 & 6 \\
August..... & 64.0 & 2.13 & 12 & 7 & 12 & 7 \\
September.. & 57.6 & 3.19 & 13 & 15 & 2 & 11 \\
\hline
\end{tabular}

Analysis of individual ears of Crosby corn grown at Orono, Me, 1905.

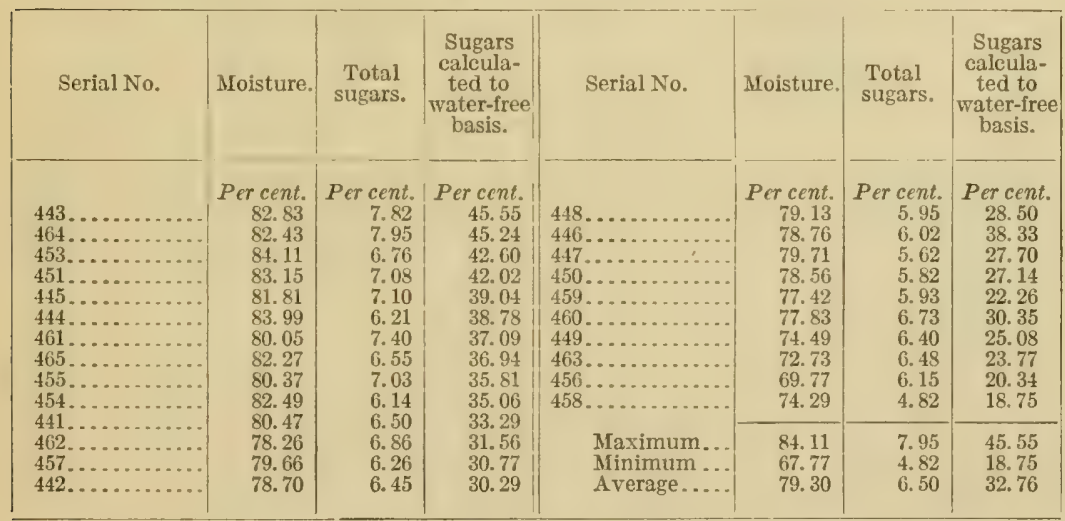

The rainfall at this station was less than in any of the other States, and the mean temperature lower, but the season appears to have been typical of the locality. The corn did not make nearly so good a growth at the Maine station as it did in Maryland or Connecticut, more nearly resembling the South Carolina corn in appearance. The percentage of sugars, however, was higher than that for the Connecticut station and lower than for the South Carolina corn. 
INFLUENCE OF RIPENESS ON SUGAR CONTENT AS JUDGED BY TASTE AND BY CHEMICAL ANALYSIS.

Samples were taken of the corn when it was in the watery, milky, and creamy stages of ripeness and a difference of 42 per cent was found between the highest and lowest percentages of sugar. In the watery stage a maximum of 54 per cent of sugar was found, and in the advanced creamy stage as low as 12 per cent of sugar, calculated to a water-free basis. As there is no absolute method of determining the state of ripeness of the corn, great care should be exercised in selecting the ears, and it is necessary to gather a large number of samples in order to secure comparable results. To afford a comparison of each day's work, the following determinations were made:

Moisture and sugar content of Stowell Evergreen corn on different dates.

SOUTH CAROLINA.

\begin{tabular}{|c|c|c|c|}
\hline Date. & Moisture. & $\begin{array}{c}\text { Total } \\
\text { sugars. }\end{array}$ & $\begin{array}{l}\text { Sugars cal- } \\
\text { culated to } \\
\text { water-free } \\
\text { basis. }\end{array}$ \\
\hline $\begin{array}{l}\text { July } 17 \ldots \ldots \\
\text { July } 18 \ldots \ldots \\
\text { July } 19 \ldots \ldots \\
\text { July } 20 \ldots \ldots \\
\text { July } 21 \ldots \ldots\end{array}$ & $\begin{array}{r}\text { Per cent. } \\
77.85 \\
76.28 \\
75.84 \\
73.87 \\
71.90\end{array}$ & $\begin{array}{r}\text { Per cent. } \\
6.98 \\
6.45 \\
7.35 \\
6.80 \\
6.82\end{array}$ & $\begin{array}{r}\text { Per cent. } \\
31.88 \\
27.31 \\
33.40 \\
26.18 \\
24.75\end{array}$ \\
\hline
\end{tabular}

MARYLAND,

\begin{tabular}{|c|c|c|c|}
\hline 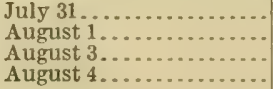 & $\begin{array}{l}77.91 \\
75.68 \\
78.85 \\
81.34\end{array}$ & $\begin{array}{l}5.86 \\
6.63 \\
5.63 \\
6.20\end{array}$ & $\begin{array}{l}25.65 \\
28.59 \\
27.10 \\
33.60\end{array}$ \\
\hline
\end{tabular}

Taking into consideration the fact that a great variation in sugar content occurs even when the ears are in the same state of ripeness, these figures show a very close average for the individual days, and are indicative of satisfactory sampling.

An effort was made to determine whether any relation exists between the taste of the corn and the percentage of sugars present. In order to accomplish this, ears which were pulled for analyses were tasted by two men and were rated, using as a scale the numbers $5,6,7,8,9$, and 10 , the highest number being used for the sweetest corn. The figures by the two tasters for each ear were averaged when they disagreed and marked opposite the serial number assigned the ear, and after completing the analyses it was possible to compare the rating thus obtained with that secured by analysis. The averages are given in the following table: 
Sugar content by chemical analysis and as indicated by taste.

[Sweetness to taste expressed by figures from 5 to 10. ]

NEW JERSEY.

\begin{tabular}{|c|c|c|}
\hline $\begin{array}{l}\text { Number of sam- } \\
\text { ples averaged. }\end{array}$ & $\begin{array}{l}\text { Sweetness } \\
\text { by taste. }\end{array}$ & $\begin{array}{c}\text { Total } \\
\text { sugars } \\
\text { calculated } \\
\text { to water- } \\
\text { free basis. }\end{array}$ \\
\hline 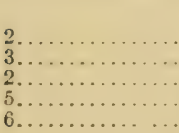 & $\begin{array}{l}9 \\
8 \\
5 \\
6 \\
5\end{array}$ & $\begin{array}{r}\text { Per cent. } \\
18.46 \\
15.25 \\
13.55 \\
11.25 \\
10.88\end{array}$ \\
\hline
\end{tabular}

CONNECTICUT

\begin{tabular}{|c|c|c|}
\hline $\begin{array}{l}2 \ldots \ldots \ldots \ldots \cdots \cdots \\
5 \ldots \ldots \ldots \cdots \cdots \\
3 \ldots \ldots \cdots \cdots \\
4 \ldots \ldots \cdots \cdots\end{array}$ & $\begin{array}{l}9 \\
8 \\
i \\
6\end{array}$ & $\begin{array}{l}26.80 \\
22.24 \\
19.53 \\
15.34\end{array}$ \\
\hline
\end{tabular}

MAINE.

\begin{tabular}{|c|c|c|}
\hline 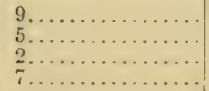 & $\begin{array}{r}10 \\
9 \\
\mathrm{~S} \\
7\end{array}$ & $\begin{array}{l}34.86 \\
24.93 \\
25.49 \\
20.34\end{array}$ \\
\hline
\end{tabular}

It will be noted that when the factor expressing the sweetness increased the sugar content also increased, one exception to this occurring in Maine, where the taste test was marked 8, and 25.49 per cent of sugar was found, while the next one, having a grade of 9 , contained only 24.93 per cent. It will also be noted that the sample graded $\delta$ by taste represented an average of only two ears, and as only a few were tasted each day it might have been that these were tried at the same time with some that were very low in sugar, having, for instance, a mark of 5, thereby giving these a higher mark than they would have obtained had they been compared with a very sweet sample graded 10. As this is the only exception at any station, it would not seem to detract from the accuracy of the method of sampling by tasting.

\section{GENERAL DISCUSSION OF DATA.}

The work on storage shows the necessity of more care in handling the corn for the market, inasmuch as the sugar content decreased, when held at room temperature for thirty-six hours, from 4.67 to 1.60 per cent after picking.

The comparison of ratings by taste with the percentage of sugars determined analytically shows that the two methods give comparable results and there seems to be a possibility of selecting and breeding corn by tasting some ears from each row, and thereby selecting seed ears from the row of corn having the highest sugar content.

One of the most interesting facts shown is the great variation in the percentage of kernels as compared with the rest of the ear. It 
seems that these observations may also be used to good effect in breeding a corn low in cob and husk percentage and high in kernel percentage. Another point is the wide variation of sugar content found in the individual ears, the highest percentage of sugar in the Stowell Evergreen corn being 40.56 per cent and the lowest 8.45 per cent of the total dry matter. In the Crosby variety a maximum of 45.55 per cent and a minimum of 19.54 per cent were found.

The general effect of environment on the sugar content of the corn is best represented by the graphic charts, and from a study of these, together with the preceding data, the following conclusions have been reached:

In figure 1 are platted the percentages of sugars in the two varieties of corn, the temperature, the altitude, and the average length of day

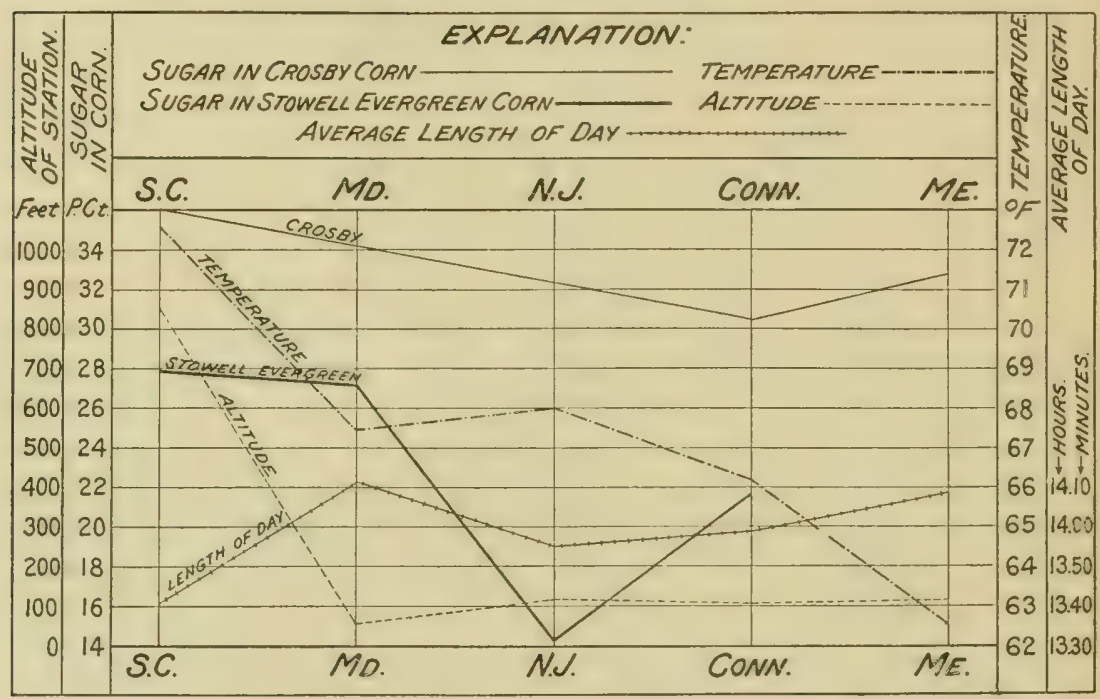

FIG. 1.-Percentage of sugar in the corn, temperature, altitude, and average length of day at the different stations, 1905.

at the several stations. There is a wide difference in the percentage of sugar present in the two varieties, the lowest arerage sugar content for the Crosby variety ( 30.44 per cent at New Haven) being 2.49 per cent higher than the maximum average for the Stowell Evergreen variety, that at Clemson College. In both varieties the highest percentage of sugars is found at the South Carolina station, while New Jersey has the lowest percentage for the Stowell Evergreen, and New IIaven the lowest for the Crosby. The Maine corn is only 3.29 per cent below South Carolina for the Crosby variety. The Maryland station figures are only slightly below those for South Carolina, and Connecticut is about half way between Maryland and New Jersey for the Stowell Evergreen.

In studying these variations it must be remembered that the character of the soils and the differences in fertilization should be 
considered. There is a great difference in the texture of the soils, although all seemed suited to the growing of corn. Three of the plats, those in South Carolina, Connecticut, and Maine, were fertilized, and the Maryland field had lain fallow for a number of years. Previous studies, however, indicate that these factors chiefly influence yield rather than composition of the crop.

There appears to be some relation between the percentage of sugar and the degree of latitude, though this is evidently not the dominant factor, and the results tend to overthrow the idea that corn grown in a southern latitude is not so sweet as that grown farther north. Although there are exceptions, it may be sail that the sugar content generally varies inversely with the latitude-that is, the percentage of sugar is lower in the higher or more northern latitude. The exception in Maine may be partly due to the altitude and to the fact that the Crosby corn, which alone was grown there, is a variety marked by high sugar content.

The fact pointed out by the Bureau of Chemistry in the work on the sugar beet ${ }^{a}$ and also demonstrated in studies made by Dr. O. Vibrans, that unobstructed sunshine is not necessury to the development of sugar in the beet, also seems to hold true with sugar corn. In the table giving a summary of meteorological data for 1905 it will be noticed that the percentage of sunshine is at its minimum at the MIaryland station, yet the sugrar content is the second highest, and the New Jersey station, with the lowest percentage of sugar, is as high as any other station in percentage of sunshine recorded. $\Lambda$ t the Maine station the clear days are few, and the cloudy and partly cloudy days are in the majority. Contrary to what might be expected from the previous study of the sugar beet, a high temperature and a low sugar content do not occur together, the opposite relation apparently existing.

The figures for the average length of day for the season in general follow those for sugar content; the longer the day the higher the percentage of sugar, as would be expected, the only notable exception to this being South Carolina, where the apparent deviations from the general rule may be partly explained by the altitude, the highest altitude and the lowest latitude being found at that station. Clemson College is 850 feet above sea level; College Park is only 56 feet above sea level. With the exception of the South Carolina station, only a slight variation in altitude exists at the other stations.

As has been already stated, the lack of rainfall may have a decided effect on the sugar content. This is especially evident at the New Jersey station, where the rainfall during the first two growing months was inadequate, stunting the corn to such an extent that the Crosby variety did not mature at all. The rainfall in South Carolina during the month of June was very small, but the deficiency occurred at a

$a$ U. S. Dept. Agr., Bureau of Chemistry, Bulletin 78, p. 42. 
time when the corn was far enough advanced to resist any detrimental effect.

The data for total precipitation and for sugar content are more nearly comparable than any other, but the distribution of rainfall is undoubtedly of more importance than the total amount, the disastrous effects of insufficient rainfall during May and June being strikingly shown in the case of the New Jersey station, even though the precipitation was normal in July, August, and September.

SUMMARY OF AVERAGE DATA FOR 1905.

Analytical data.

\begin{tabular}{|c|c|c|c|c|c|c|}
\hline \multirow{4}{*}{ Station. } & \multicolumn{6}{|c|}{ Variety of corn. } \\
\hline & \multicolumn{3}{|c|}{ Crosby. } & \multicolumn{3}{|c|}{ Stowell Evergreen. } \\
\hline & \multirow[b]{2}{*}{ Mfoisture. } & \multicolumn{2}{|c|}{ Total sugars. } & \multirow[b]{2}{*}{ Moisture. } & \multicolumn{2}{|c|}{ Total sugars. } \\
\hline & & $\begin{array}{l}\text { Original } \\
\text { sample. }\end{array}$ & $\begin{array}{l}\text { Calcu- } \\
\text { lated to } \\
\text { water- } \\
\text { free basis. }\end{array}$ & & $\begin{array}{l}\text { Original } \\
\text { sample. }\end{array}$ & $\begin{array}{l}\text { Calcu. } \\
\text { lated to } \\
\text { water- } \\
\text { iree basis. }\end{array}$ \\
\hline $\begin{array}{l}\text { Clemson College, S. C.... } \\
\text { College Park, Md....... } \\
\text { New Brunswick, N. J... } \\
\text { New Haven, Conn..... } \\
\text { Orono, Me.............. }\end{array}$ & \begin{tabular}{r} 
Per cent. \\
65.84 \\
\hdashline \\
\hdashline 73.01 \\
79.30
\end{tabular} & \begin{tabular}{r} 
Per cent. \\
12.22 \\
\hdashline \\
7.73 \\
6.50
\end{tabular} & $\begin{array}{r}\text { Per cent. } \\
36.05 \\
\ldots \ldots \\
30 . \\
32.44 \\
32.76\end{array}$ & $\begin{array}{r}\text { Per cent. } \\
75.54 \\
78.13 \\
69.28 \\
74.62 \\
\ldots \ldots . . .\end{array}$ & $\begin{array}{r}\text { Per cent. } \\
6.68 \\
5.78 \\
4.26 \\
5.36\end{array}$ & $\begin{array}{r}\text { Per cent. } \\
27.95 \\
27.18 \\
14.12 \\
21.70 \\
\ldots \ldots . . .\end{array}$ \\
\hline
\end{tabular}

Meteorological data.

\begin{tabular}{|c|c|c|c|c|c|c|}
\hline Station. & $\begin{array}{c}\text { Tempera- } \\
\text { ture. }\end{array}$ & $\begin{array}{c}\text { Precipi- } \\
\text { tation. }\end{array}$ & $\begin{array}{l}\text { Clear } \\
\text { days. }\end{array}$ & $\begin{array}{l}\text { Cloudy } \\
\text { days. }\end{array}$ & $\begin{array}{l}\text { Partly } \\
\text { cloudy } \\
\text { days. }\end{array}$ & $\begin{array}{l}\text { Sun- } \\
\text { shine. }\end{array}$ \\
\hline 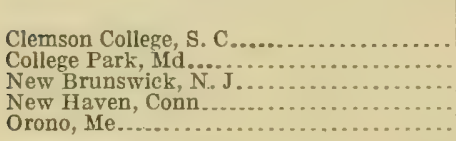 & $\begin{array}{l}{ }^{\circ} \mathrm{F} . \\
72.7 \\
67.6 \\
68.0 \\
66.2 \\
62.7\end{array}$ & $\begin{array}{r}\text { Inches. } \\
19.80 \\
24.49 \\
16.91 \\
17.11 \\
10.64\end{array}$ & $\begin{array}{r}80 \\
104 \\
87 \\
45 \\
45\end{array}$ & $\begin{array}{l}21 \\
31 \\
22 \\
32 \\
45\end{array}$ & $\begin{array}{r}21 \\
44 \\
32\end{array}$ & $\begin{array}{r}\text { Per cent. } \\
a 61 \\
c 52 \\
d 61 \\
60\end{array}$ \\
\hline
\end{tabular}

$a$ Per cent of sunshine for A tlanta, Ga. $b$ Partiy cloudy days included.

c Per cent of sunshine for Washington, D. C. d Per cent of sunshine for Philadelphia, $\mathrm{Pa}$.

Geodetic data.a

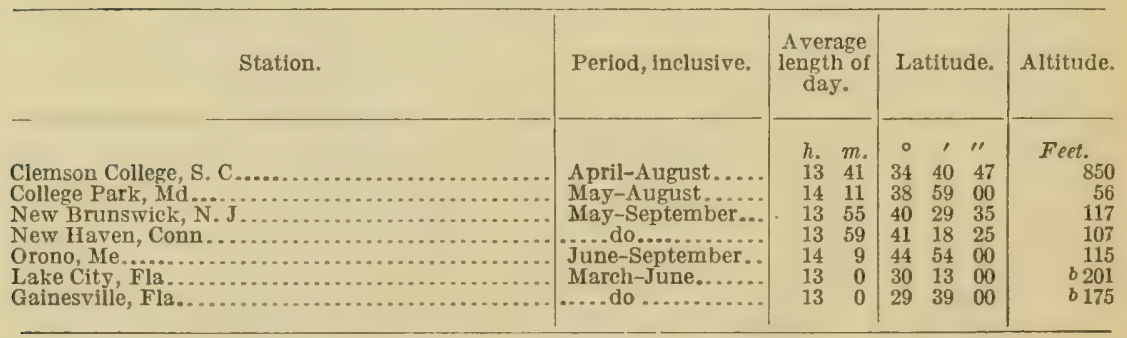

a These data were furnished by the United States Coast and Geodetic Survey.

b From the monthly report of the United States W eather Bureau. 


\section{INVESTIGATION OF 1906.}

\section{CHANGES IN THE ORGANIZATION OF THE WORK.}

At the opening of the season of 1906 the Bureau of Plant Industry signified its desire to cooperate in the work on sweet corn, the object being to improve the quality of the product with special reference to increasing the sugar content and securing varieties adapted to different sections of the country. The results on the breeding work and the adaptation of varieties, in accordance with the understanding between the two Bureaus, will be interpreted by the Bureau of Plant Industry, while the effect produced by the environment on the composition of the corn is published by the Bureau of Chemistry as being a purely chemical study.

It was thought desirable, owing to the results obtained at the South Carolina station during the season of 1905 , to extend the work to Florida. A letter was accordingly sent to each of the followingnamed experiment stations: Florida, South Carolina, Maryland, New Jersey, Connecticut, and Maine. Favorable replies were received from all except the New Jersey station, where all the land adapted to these investigations had been allotted to other experiments.

\section{METHODS OF PLANTING AND SAMPLING.}

One object of the work being to secure corn having a high sugar content, it was decided to plant the corn by the ear-to-row method and to analyze a number of ears from each row, the seed from the row averaging the highest in sugar content to be selected, taking into consideration the form of the ear, the yield per row, etc.

The method of selecting seed corn followed at the Maryland experiment station during the season of 1905 indicates which ears have the highest sugar content at the edible stage, and also whether any relation exists between sugar content of the green corn and the dried seed. The plan in brief was to draw the husk back from a portion of the ear, remove two or three rows of kernels, replace the husk carefully, tie a paper bag over the entire ear to prevent injury by insects or rain, and allow the ear to mature, which it did without any apparent injurious effect. This sample was analyzed and compared with one taken from the ear when fully ripe to determine whether there is any correlation between the amount of sugar in the green (edible) ear and the dried seed.

In accordance with this plan two varieties of corn were secured from New York State by the Bureau of Plant Industry and ears suited to the purpose were selected. The ears were all given a serial number, and samples were taken from them for analysis. Twenty ears of each variety, which had been sampled and analyzed, were sent to each station with instructions for planting, keeping of meteorological data, etc. 
The work of the previous year had demonstrated the fact that very rapid changes take place in the sugars soon after removing the kernels from the cob; and as the plats were located at distances from the laboratory varying from a quarter of a mile to a mile and a half, this, together with the necessity of analyzing a large number of samples, required some change in the mode of analytical work. It was finally decided to work in a wall tent pitched as near the plat of corn as possible, prepare the sample, weigh out the portion to be used, and heat this to boiling with a 40 per cent alcoholic solution for two hours, so that the sugars would not only be extracted but any changes in them would be rendered impossible. The samples could then be set aside until the end of the day, before being taken to the laboratory, made to a definite volume, and an aliquot kept until the determination could be completed.

\section{FLORIDA.}

A sandy soil, upon which corn had previously been grown, was used at the Florida station for the Crosby corn. The ground was prepared by plowing 4 inches deep with an ordinary two-horse plow, and fertilized to the extent of 300 pounds per acre with fertilizer containing 3 per cent of ammonia, 6 per cent of phosphoric acid, and 8 per cent of potash. The date of planting was March 17, the corn coming up March 30. The plants were cultivated twice-April 16 with a five-tooth cultivator and on April 24 with a weeder. The corn tasseled on May 7, reached the stage suitable for table use May 29, and was ready for seed harvest June 27.

The Stowell Evergreen corn was also grown on a sandy soil which for three years prior to this had been planted in northern varieties of corn and on which fertilizer containing 4 per cent of ammonia, 6 per cent of phosphoric acid, and 8 per cent of potash had been applied at the rate of 300 pounds per acre. The ground was prepared in the same way as for the Crosby corm, and the character of the fertilization was identical with that given for the previous crops. The dates of planting and coming up and the dates and methods of cultivation were the same as for the Crosby corn. The first tassels appeared May 9, the corn was ready for table use June 2, and the matured seed was in a condition to harvest July 4.

The meteorological and analytical data for this station follow:

Meteorological data for Lake City, Fla., 1906.

\begin{tabular}{|c|c|c|c|c|c|}
\hline Month. & $\begin{array}{c}\text { Mean } \\
\text { tempera- } \\
\text { ture. }\end{array}$ & $\begin{array}{l}\text { Precipi- } \\
\text { tation. }\end{array}$ & $\begin{array}{l}\text { Clear } \\
\text { days. }\end{array}$ & $\begin{array}{l}\text { Partly } \\
\text { cloudy. }\end{array}$ & $\begin{array}{l}\text { Cloudy } \\
\text { days. }\end{array}$ \\
\hline $\begin{array}{l}\text { Marah .... } \\
\text { April ..... } \\
\text { May.... } \\
\text { June..... }\end{array}$ & $\begin{array}{l}{ }^{\circ} F \text {. } \\
61.2 \\
68.7 \\
73.6 \\
80.6\end{array}$ & $\begin{array}{r}\text { Inches. } \\
2.78 \\
1.70 \\
9.96 \\
8.22\end{array}$ & $\begin{array}{r}8 \\
17 \\
8 \\
1\end{array}$ & $\begin{array}{r}8 \\
5 \\
10 \\
24\end{array}$ & $\begin{array}{r}15 \\
8 \\
13 \\
5\end{array}$ \\
\hline
\end{tabular}


Analysis of individual ears of Crosby corn grown at Lake City, Fla., 1906.

\begin{tabular}{|c|c|c|c|c|c|c|c|}
\hline Serial No. & Moisture. & $\begin{array}{c}\text { Total } \\
\text { sugars. }\end{array}$ & \begin{tabular}{|c|} 
Sugars \\
calcula- \\
ted to \\
water-free \\
basis.
\end{tabular} & Serial No. & Moisture. & $\begin{array}{c}\text { Total } \\
\text { sugars. }\end{array}$ & $\begin{array}{l}\text { Sugars } \\
\text { calcula- } \\
\text { ted to } \\
\text { water-free } \\
\text { basis. }\end{array}$ \\
\hline 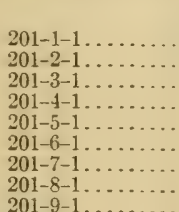 & $\begin{array}{r}\text { Per cent. } \\
62.15 \\
67.84 \\
67.50 \\
68.03 \\
70.17 \\
60.87 \\
68.00 \\
72.04 \\
73.69\end{array}$ & $\begin{array}{r}\text { Per cent. } \\
5.20 \\
4.53 \\
5.83 \\
4.43 \\
7.43 \\
3.20 \\
4.22 \\
4.90 \\
4.19\end{array}$ & \begin{tabular}{r|} 
Per cent, \\
13.74 \\
14.08 \\
16.59 \\
14.01 \\
24.91 \\
8.11 \\
13.80 \\
17.52 \\
15.92
\end{tabular} & 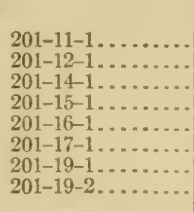 & $\begin{array}{r}\text { Per cent. } \\
64.60 \\
67.78 \\
62.56 \\
73.67 \\
69.58 \\
72.38 \\
69.22 \\
67.56\end{array}$ & $\begin{array}{r}\text { Per cent. } \\
4.46 \\
6.39 \\
3.98 \\
5.48 \\
4.96 \\
4.88 \\
5.54 \\
4.90\end{array}$ & $\begin{array}{c}\text { Per cent. } \\
12.60 \\
19.83 \\
10.63 \\
20.81 \\
16.30 \\
17.67 \\
18.00 \\
15.11\end{array}$ \\
\hline $\begin{array}{l}201-10-1 \ldots \ldots \ldots \\
201-9-2 \ldots \ldots \ldots \\
201-9-3 \ldots \ldots \ldots \\
201-9-4 \ldots \ldots \ldots\end{array}$ & \begin{tabular}{|}
62.45 \\
67.00 \\
67.40 \\
61.94
\end{tabular} & $\begin{array}{l}3.99 \\
5.37 \\
5.64 \\
5.62\end{array}$ & $\begin{array}{l}10.63 \\
16.27 \\
17.30 \\
14.76\end{array}$ & $\begin{array}{l}\text { Marimum... } \\
\text { Minimum... } \\
\text { Average.... }\end{array}$ & $\begin{array}{l}73.69 \\
61.94 \\
67.11\end{array}$ & $\begin{array}{l}7.43 \\
3.20 \\
5.01\end{array}$ & $\begin{array}{r}24.91 \\
8.11 \\
15.64\end{array}$ \\
\hline
\end{tabular}

Analysis of individual ears of Stowell Evergreen corn grown at Lake City, Fla., 1906.

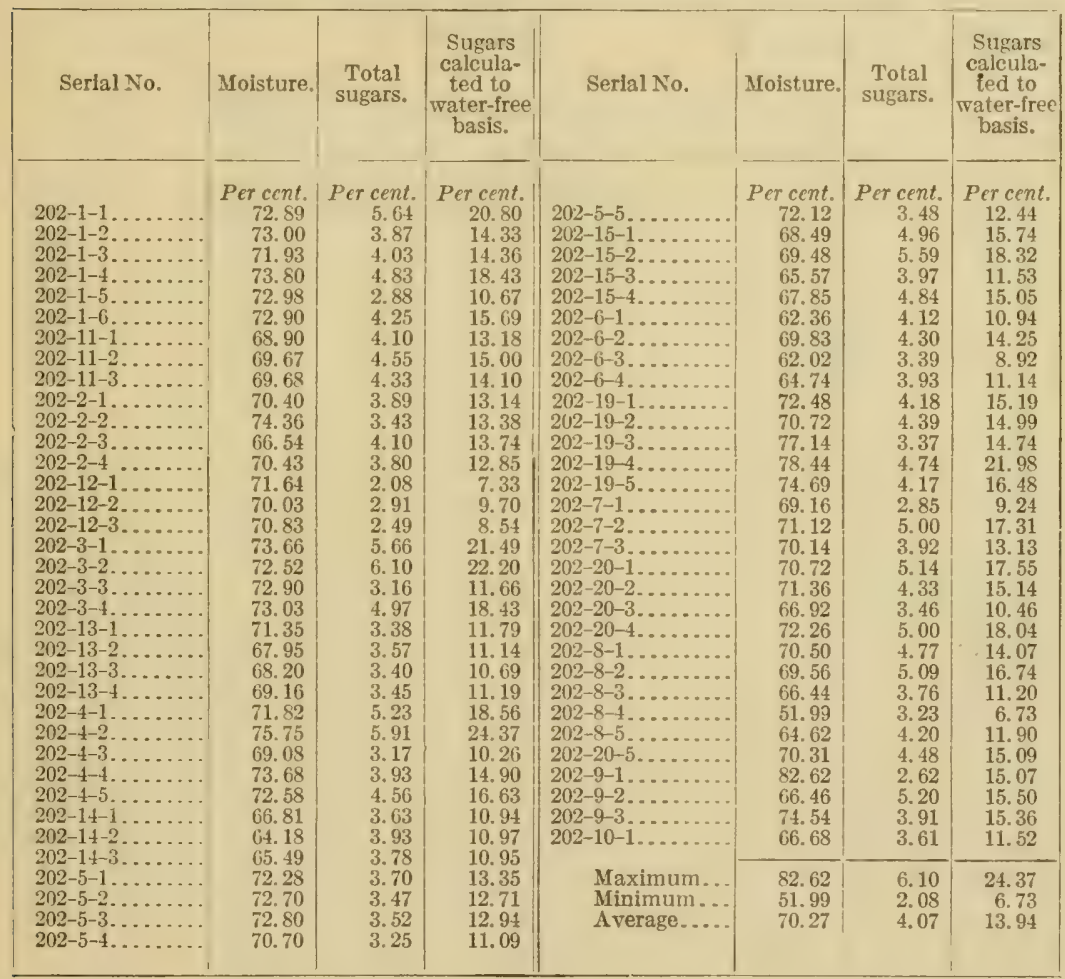

The total rainfall for 1906 was far above the normal amount for the growing season. For the week previous to the harvesting of the corn there were five rainfalls recorded, and during the harvest period occupying one week rain fell four times, the rains being heavy. On 
the second day of harvest 2.97 inches of rain fell, on the third day 1.4 inches, on the sixth day 0.84 inch, and on the seventh day 1.12 inches. Such heavy precipitation would probably tend to produce a corn with low total sugar content.

Florida stood last in percentage of sugars as compared with the other stations for the Stowell Evergreen and next to last for the Crosby. Both varieties of corn were attacked by the worms and weevils.

\section{SOUTH CAROLINA.}

The field used for growing the sweet corn at the South Carolina station was a plat of sandy loam-about one-tenth of an acre. A complete fertilizer was used, 400 pounds to the acre. The corn did not make a very vigorous growth, and the ears themselves were small and inferior, although the analytical data show a high percentage of sugar. The Crosby corn reached the edible state July 17 and the Stowell on July 24.

Meteorological data for Clemson College, S. C., 1906.

\begin{tabular}{|c|c|c|c|c|c|}
\hline Month. & $\begin{array}{c}\text { Mean } \\
\text { tempera- } \\
\text { ture. }\end{array}$ & $\begin{array}{l}\text { Precipi- } \\
\text { tation. }\end{array}$ & $\begin{array}{l}\text { Clear } \\
\text { days. }\end{array}$ & $\begin{array}{l}\text { Cloudy } \\
\text { days. }\end{array}$ & $\begin{array}{l}\text { Partly } \\
\text { cloudy. }\end{array}$ \\
\hline $\begin{array}{l}\text { April.... } \\
\text { May..... } \\
\text { June..... } \\
\text { July..... }\end{array}$ & $\begin{array}{l}\circ F . \\
63.0 \\
69.0 \\
76.8 \\
77.5\end{array}$ & $\begin{array}{r}\text { Inches. } \\
1.89 \\
2.74 \\
5.67 \\
17.77\end{array}$ & $\begin{array}{r}21 \\
21 \\
16 \\
9\end{array}$ & $\begin{array}{l}2 \\
4 \\
4 \\
7\end{array}$ & $\begin{array}{r}7 \\
6 \\
10 \\
15\end{array}$ \\
\hline
\end{tabular}

The number of clear days for April to July, inclusive, at Clemson College was 67 , which was less than in 1905 , when 80 clear days were recorded. The total number of inches of rainfall was less than for 1905, and was very unevenly distributed; most of it fell during a period when it seemed to affect the corn more. During the five days previous to harvesting the corn three rains fell, on the following dates: July 14, 0.9 inch; July 15, 3.06 inches; and July 16, 0.3 inch. On July 17 , the day on which harvest began, 1.35 inches fell; July 18, 0.1 inch; July 19, 1.26 inches; July 21, 1.23 inches; July 23, 1.25 inches; and on July 25, the last day upon which any samples were pulled, 2.1 inches. This heavy rainfall undoubtedly would cause a decrease in the usual amount of sugars stored. Both varieties of corn wore inferior in yield and quality to the crops of 1905 .

As the corn was very late in ripening, and the crop at the Maryland station was ready for harvesting, only a few analyses of the Crosby variety were made at Clemson College. The data obtained for both varieties are as follows: 
Analysis of individual ears of Crosby corn grown at Clemson College, S. C., 1906.

\begin{tabular}{|c|c|c|c|}
\hline Serial No. & Moisture. & $\begin{array}{c}\text { Total } \\
\text { sugars. }\end{array}$ & $\begin{array}{l}\text { Sugars cal- } \\
\text { culated to } \\
\text { water-free } \\
\text { basis. }\end{array}$ \\
\hline $\begin{array}{l}204-1-1 \ldots \ldots \ldots \ldots \\
204-2-1 \ldots \ldots \ldots \ldots \\
204-3-1, \ldots \ldots \ldots \\
204-4-1 \ldots \ldots \ldots \\
204-5-1 \ldots \ldots \ldots\end{array}$ & $\begin{array}{r}\text { Per cent. } \\
81.57 \\
75.35 \\
75.70 \\
78.11 \\
73.14\end{array}$ & $\begin{array}{r}\text { Per cent. } \\
4.69 \\
4.55 \\
5.03 \\
4.34 \\
5.04\end{array}$ & $\begin{array}{r}\text { Per cent. } \\
25.45 \\
18.46 \\
20.70 \\
19.83 \\
18.76\end{array}$ \\
\hline $\begin{array}{l}\text { Maximum.. } \\
\text { Minimum.. } \\
\text { Average.... }\end{array}$ & $\begin{array}{l}81.57 \\
73.14 \\
76.77\end{array}$ & $\begin{array}{l}5.04 \\
4.34 \\
4.73\end{array}$ & $\begin{array}{l}25.45 \\
18.46 \\
20.64\end{array}$ \\
\hline
\end{tabular}

Analysis of individual ears of Stowell Evergrcen corn grown at Clemson College, S. C., 1906.

\begin{tabular}{|c|c|c|c|c|c|c|c|}
\hline Serial No. & Moisture. & $\begin{array}{c}\text { Total } \\
\text { sugars. }\end{array}$ & $\begin{array}{c}\text { Sugars } \\
\text { calculated } \\
\text { to water- } \\
\text { free basis. }\end{array}$ & Serial No. & Moisture. & $\begin{array}{c}\text { Total } \\
\text { sugars. }\end{array}$ & $\begin{array}{l}\text { Sugars } \\
\text { calculated } \\
\text { to water- } \\
\text { free basis. }\end{array}$ \\
\hline $\begin{array}{l}203-5-1 \ldots \\
203-5-2 \ldots \\
203-5-3 . \\
203-5-4 \\
203-4 . \\
203-1.2 \\
203-4-3 \\
203-6-1 \ldots \\
203-6-2 \ldots \\
203-6-3 \ldots \\
203-6-4 \ldots \\
203-6-5\end{array}$ & $\begin{array}{r}\text { Per cent. } \\
72.25 \\
85.30 \\
68.97 \\
68.10 \\
68.34 \\
72.02 \\
70.92 \\
69.21 \\
74.45 \\
69.01 \\
70.28 \\
73\end{array}$ & $\begin{array}{r}\text { Per cent. } \\
5.56 \\
3.70 \\
4.12 \\
4.33 \\
5.19 \\
5.32 \\
5.34 \\
5.43 \\
5.69 \\
5.27 \\
5.68 \\
4.95\end{array}$ & $\begin{array}{r}\text { Per cent. } \\
22.46 \\
25.17 \\
13.29 \\
13.57 \\
16.39 \\
19.00 \\
18.36 \\
17.63 \\
22.27 \\
17.01 \\
19.11\end{array}$ & $\begin{array}{l}203-9-1 . \ldots \\
203-9-2 . \ldots \\
203-9-3 . \ldots \\
203-10-1 . \ldots \\
203-10-2 . \\
203-23-1 . \\
203-23-2 . \\
203-16-1 . \\
203-16-2 . \\
203-3-1 . \\
203-3-2 . \\
.\end{array}$ & $\begin{array}{r}\text { Per cent. } \\
74.68 \\
71.09 \\
69.62 \\
74.82 \\
71.84 \\
69.55 \\
67.16 \\
72.35 \\
70.34 \\
76.04 \\
71.15\end{array}$ & $\begin{array}{r}\text { Per cent. } \\
6.35 \\
4.22 \\
6.02 \\
5.27 \\
6.17 \\
3.92 \\
3.95 \\
5.40 \\
4.14 \\
4.57 \\
6.42\end{array}$ & $\begin{array}{c}\text { Per cent. } \\
25.08 \\
14.60 \\
19.82 \\
20.93 \\
21.91 \\
12.87 \\
12.03 \\
19.53 \\
14.15 \\
19.07 \\
22.25\end{array}$ \\
\hline $\begin{array}{l}203-7-1 \ldots \\
203-7-2 \ldots \\
203-7-3 .\end{array}$ & $\begin{array}{l}72.59 \\
72.48 \\
68.88\end{array}$ & $\begin{array}{l}4.48 \\
4.07 \\
4.23\end{array}$ & $\begin{array}{l}16.34 \\
14.79 \\
13.59\end{array}$ & $\begin{array}{l}\text { Maximum } \\
\text { Minimum. } \\
\text { Average. - }\end{array}$ & $\begin{array}{l}85.30 \\
67.16 \\
71.72\end{array}$ & $\begin{array}{l}6.42 \\
3.70 \\
4.99\end{array}$ & $\begin{array}{l}25.17 \\
12.03 \\
18.07\end{array}$ \\
\hline
\end{tabular}

\section{MARYLAND.}

At the Maryland station the Stowell Evergreen and the Crosby corn were grown on the same plat as that used for the 1905 experiments. It was plowed April 30, 1906, floated, and 20 bushels of lime per acre applied. On May 3 the plat was thoroughly harrowed and rolled, and the corn was planted May 5 , in rows 3 feet 9 inches apart, the hills being 15 inches apart. A small tooth cultivator and a riding plow were used in cultivating it June 7 and 17 and July 2 and 16. The corn was ready for the table about the first of August and the matured corn was ready for harvesting September 29.

The rainfall was excessive, especially in August, which made it impossible to cultivate the corn properly, and grass and weeds were consequently very abundant. The large number of rains, twentythree, coming at the time when the corn was maturing, caused a great many of the ears to mold, especially those which had been 
opened for the purpose of sampling. The detailed meteorological data are as follows:

Meteorological data for College Park, IId., 1906.

\begin{tabular}{|c|c|c|c|c|c|}
\hline Month. & $\begin{array}{l}\text { Mean } \\
\text { tempera- } \\
\text { ture. }\end{array}$ & $\begin{array}{l}\text { Precip- } \\
\text { itation. }\end{array}$ & $\begin{array}{l}\text { Clear } \\
\text { days. }\end{array}$ & $\begin{array}{l}\text { Cloudy } \\
\text { days. }\end{array}$ & $\begin{array}{l}\text { Num- } \\
\text { ber of } \\
\text { rains. }\end{array}$ \\
\hline $\begin{array}{l}\text { April....... } \\
\text { May........ } \\
\text { June...... } \\
\text { July ........ } \\
\text { August.... }\end{array}$ & $\begin{array}{r}{ }^{\circ} F \\
55 \\
63 \\
72 \\
75 \\
77\end{array}$ & $\begin{array}{r}\text { Inches. } \\
3.44 \\
1.73 \\
7.56 \\
6.81 \\
9.34\end{array}$ & $\begin{array}{r}15 \\
16 \\
9 \\
7 \\
3\end{array}$ & $\begin{array}{r}8 \\
2 \\
4 \\
1 \\
18\end{array}$ & $\begin{array}{r}11 \\
6 \\
14 \\
12 \\
16\end{array}$ \\
\hline
\end{tabular}

The number of clear days in June, 1906, was only 9, while June, 1905, showed 21. In July, 1906, there were 7 clear days and in July, 1905, the record shows 19 clear days. The rainfall for June, 1906, was 7.56 inches and for June, 1905, 3.77 inches. The amounts for July, 1906 and 1905, were nearly equal, being 6.S1 and 6.97 inches, respectively. During the period just previous to harvesting very frequent rainfalls were recorded, among which were sereral excessively heavy ones. An extremely abundant crop of corn was harvested this year, the ears being large and well filled but not so sweet as usual.

For the Stowell Evergreen variety a maximum of 39.50 per cent, a minimum of 18.89 per cent, and an average of 27.18 per cent of sugars in the total dry substance were found in 1905. In 1906 the maximum was 22.19 per cent, the minimum, 7.14 per cent, and the average 13.87 per cent, these figures having been obtained from the results on 112 ears of corn. The Crosby variety gave the following results: Maximum sugar content, 32.44 per cent; minimum, 11.25 per cent; and arerage, 17.46 per cent. The detailed analytical results follow:

Analysis of individual ears of Crosby corn grown at College Park, MId., 1906.

\begin{tabular}{|c|c|c|c|c|c|c|c|}
\hline Serial No. & Moisture. & $\begin{array}{c}\text { Total } \\
\text { sugars. }\end{array}$ & \begin{tabular}{|} 
Sugars \\
calculated \\
to water- \\
free basls.
\end{tabular} & Serial No. & Moisture. & $\begin{array}{l}\text { Total } \\
\text { sugars. }\end{array}$ & $\begin{array}{c}\text { Sugars } \\
\text { calculated } \\
\text { to water- } \\
\text { free basis. }\end{array}$ \\
\hline 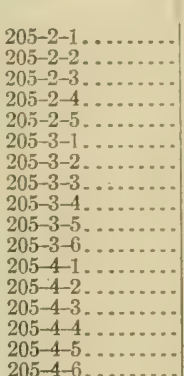 & $\begin{array}{r}\text { Per cent. } \\
68.88 \\
63.20 \\
61.90 \\
72.40 \\
65.59 \\
69.35 \\
65.86 \\
63.54 \\
70.06 \\
64.56 \\
66.67 \\
70.57 \\
62.82 \\
60.88 \\
71.64 \\
66.74 \\
66.53\end{array}$ & $\begin{array}{r}\text { Per cent. } \\
4.51 \\
4.14 \\
4.65 \\
5.59 \\
4.72 \\
3.82 \\
4.18 \\
5.24 \\
4.21 \\
5.59 \\
4.61 \\
3.57 \\
5.03 \\
4.61 \\
5.43 \\
5.37 \\
4.80\end{array}$ & \begin{tabular}{|r|} 
Per cent. \\
14.49 \\
11.25 \\
12.21 \\
20.25 \\
14.13 \\
12.46 \\
12.24 \\
14.37 \\
14.00 \\
15.57 \\
13.83 \\
12.13 \\
13.53 \\
11.79 \\
19.15 \\
16.18 \\
14.34
\end{tabular} & 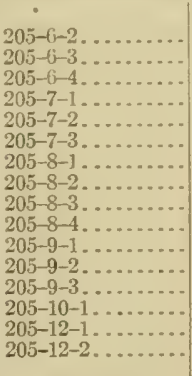 & $\begin{array}{r}\text { Per cent. } \\
68.66 \\
76.50 \\
75.50 \\
66.60 \\
71.18 \\
68.89 \\
77.38 \\
74.09 \\
70.57 \\
74.01 \\
77.06 \\
82.80 \\
79.93 \\
66.42 \\
71.82 \\
66.50\end{array}$ & $\begin{array}{r}\text { Per cent. } \\
5.12 \\
6.41 \\
5.86 \\
4.20 \\
4.76 \\
4.48 \\
5.64 \\
5.80 \\
5.69 \\
5.71 \\
5.90 \\
4.46 \\
5.18 \\
3.90 \\
5.83 \\
6.08\end{array}$ & $\begin{array}{c}\text { Percent. } \\
16.35 \\
27.28 \\
23.92 \\
12.58 \\
16.53 \\
14.40 \\
24.96 \\
22.48 \\
19.35 \\
21.97 \\
25.77 \\
25.93 \\
25.81 \\
11.61 \\
20.69 \\
18.15\end{array}$ \\
\hline $\begin{array}{l}205-5-1 . \ldots \ldots \ldots \\
205-5-2 \ldots \ldots \ldots \\
205-5-3 \ldots \ldots \ldots \\
205-6-1 . \ldots \ldots\end{array}$ & $\begin{array}{l}68.65 \\
66.50 \\
66.57 \\
81.35\end{array}$ & $\begin{array}{l}5.16 \\
4.37 \\
4.76 \\
6.05\end{array}$ & $\begin{array}{l}16.46 \\
13.04 \\
14.24 \\
32.44\end{array}$ & $\begin{array}{l}\text { Maximum... } \\
\text { Minimum... } \\
\text { Average.... }\end{array}$ & $\begin{array}{l}82.80 \\
60.88 \\
69.79\end{array}$ & $\begin{array}{l}6.41 \\
3.57 \\
5.01\end{array}$ & $\begin{array}{l}32.44 \\
11.25 \\
17.46\end{array}$ \\
\hline
\end{tabular}


Analysis of individual ears of Stowell Evergreen corn grown at College Park, Md., 1906.

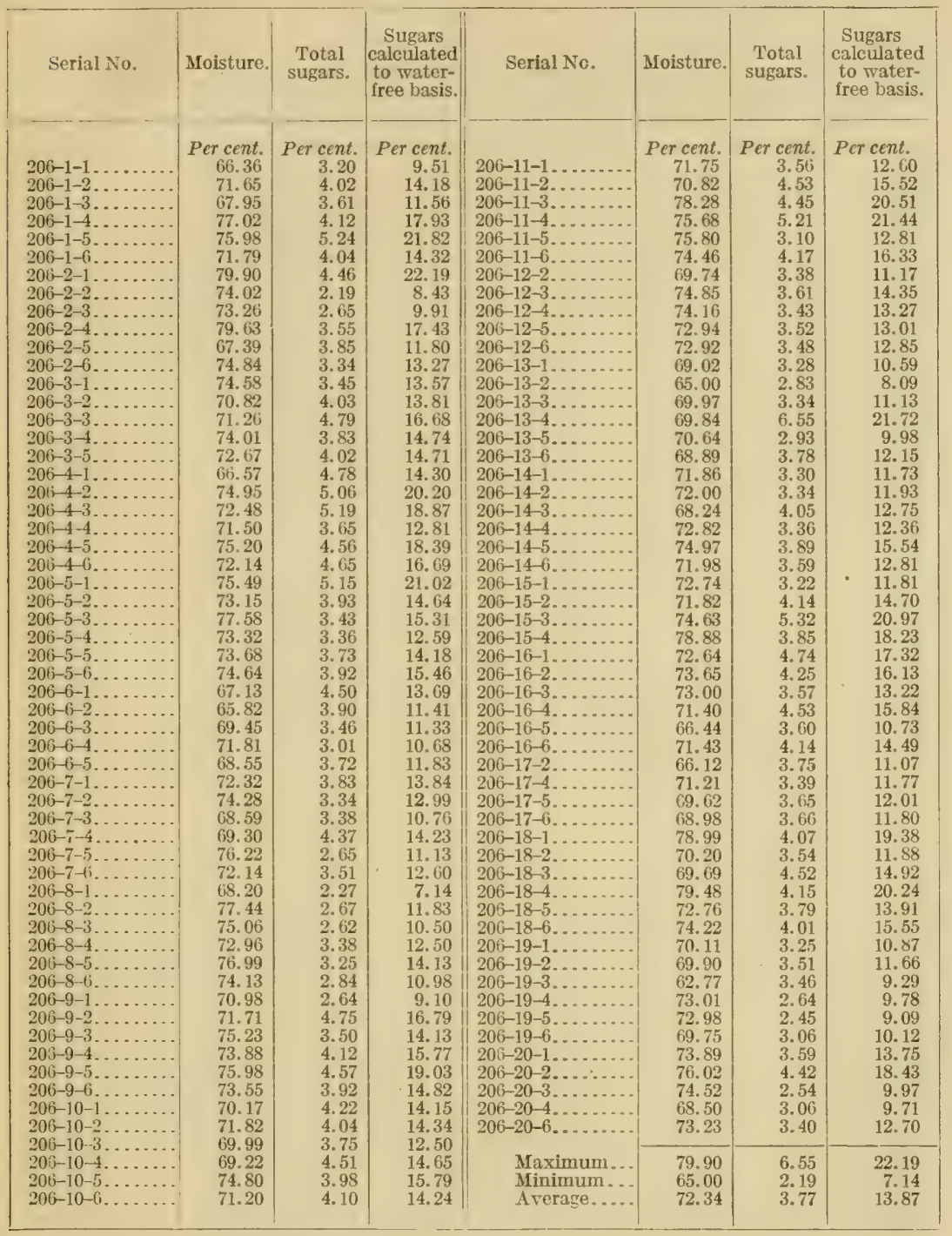

\section{CONNECTICUT.}

The corn was planted at Orange, about three miles from New Haven, the plat used for the Crosby variety being a sandy loam previously used for tomatoes. The soil was thoroughly tilled and 600 pounds per acre of a high-grade fertilizer, containing 4 per cent of nitrogen, 8 per cent of phosphoric acid, and 8 per cent of potash, was applied. The corn was planted May 12, and cultivated with a horse cultivator 
about every two weeks. It was ready for the table about September 10 , and the mature ears were picked October 4.

For the Stowell Evergreen a hardpan subsoil was used which had been planted in cucumbers in 1905. This corn was planted May 16, the cultivation and fertilization being the same as for the Crosby variety. On September 20) it was ready for table use, and the mature ears were harvested October 4.

In Connecticut, as at each of the other stations, a lower percentage of sugars was obtained for both varieties of corn in 1906. At this point, though the total rainfall was slightly greater than in 1905 , for three weeks previous to the harvesting of the crop less than 0.1 inch of rain fell. In percentage of sugars Connecticut stood last of all the stations cooperating, and the sugar content was less than that obtained at the New Jersey station in 1905.

The detailed analytical and meteorological data are appended.

Meteorological data for New Haven, Conn., 1906.

\begin{tabular}{|c|c|c|c|c|c|}
\hline Month. & $\begin{array}{l}\text { Mean } \\
\text { tempera- } \\
\text { ture. }\end{array}$ & $\begin{array}{l}\text { Precipi- } \\
\text { tation. }\end{array}$ & $\begin{array}{l}\text { Clear } \\
\text { days. }\end{array}$ & $\begin{array}{l}\text { Cloudy } \\
\text { days. }\end{array}$ & $\begin{array}{l}\text { Num- } \\
\text { ber of } \\
\text { rains. }\end{array}$ \\
\hline $\begin{array}{l}\text { May....... } \\
\text { June....... } \\
\text { July....... } \\
\text { August.... } \\
\text { September. }\end{array}$ & $\begin{array}{l}\circ F . \\
58.7 \\
67.9 \\
71.8 \\
73.1 \\
66.4\end{array}$ & $\begin{array}{r}\text { Inches. } \\
4.75 \\
5.14 \\
5.62 \\
1.13 \\
4.82\end{array}$ & $\begin{array}{r}12 \\
10 \\
10 \\
9 \\
15\end{array}$ & $\begin{array}{l}9 \\
6 \\
9 \\
8 \\
6\end{array}$ & $\begin{array}{r}10 \\
11 \\
16 \\
8 \\
6\end{array}$ \\
\hline
\end{tabular}

Analysis of individual ears of Crosby corn grown at Orange, Conn., 1906.

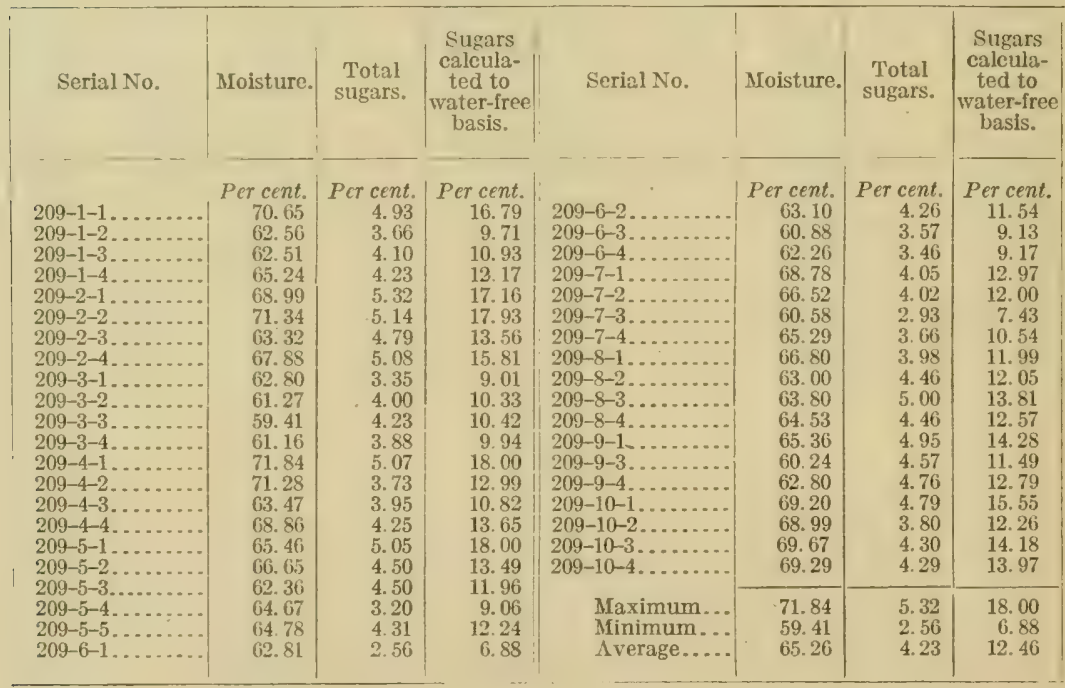


Analysis of individual ears of Stowell Evergreen corn grown at Orange, Conn., 1906.

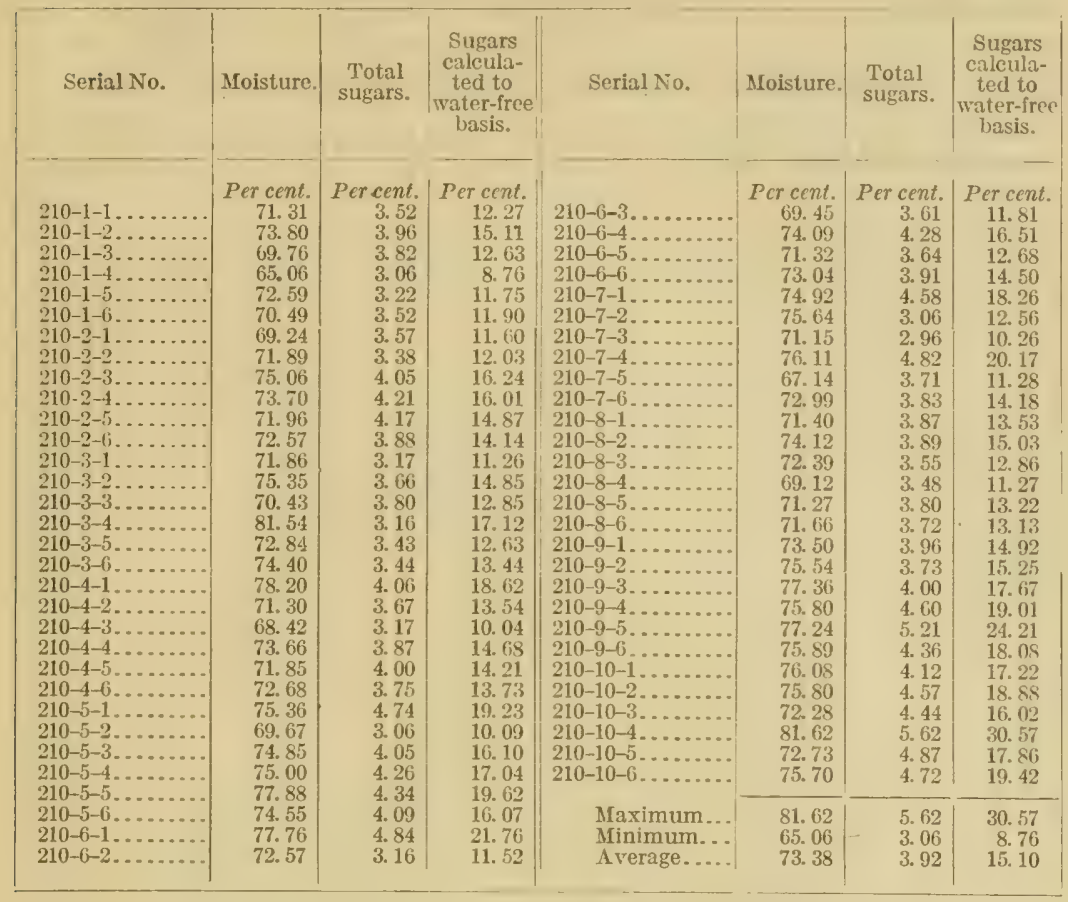

\section{MAINE.}

At the Maine station one-half acre of Crosby corn was planted on June 5, 1906, and carefully cultirated throughout the season. The soil was a strong clay loam which had been used in 1904 for cabbage and corn, and in 1905 for a variety test of peas. In the fall of 1905 a heavy application of stable manure was made, and at the time of planting about 400 pounds of a high-grade complete commercial fertilizer was used. The characteristics of the 1906 season at the Maine station are shown by the following data:

Meteorological data for Orono, Me., 1906.

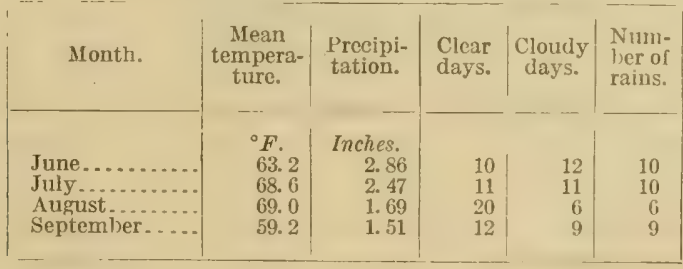


The total rainfall at the Maine station was less in 1906 than in 1905 and yet the number of rains was greater. The mean temperature for August, 1906, was 5 degrees above that given for August, 1905. The analysis of the crop gave the following figures:

Analysis of individual ears of Crosby corn grown at Orono, Me., 1906.

\begin{tabular}{|c|c|c|c|c|c|c|c|}
\hline Serial No. & Moisture. & $\begin{array}{c}\text { Total } \\
\text { sugars. }\end{array}$ & $\begin{array}{c}\text { Sugars } \\
\text { calcula- } \\
\text { ted to } \\
\text { water-free } \\
\text { basis. }\end{array}$ & Serial No. & Moisture. & $\begin{array}{c}\text { Total } \\
\text { sugars. }\end{array}$ & $\begin{array}{c}\text { Sugars } \\
\text { calcula- } \\
\text { ted to } \\
\text { water-free } \\
\text { basis. }\end{array}$ \\
\hline 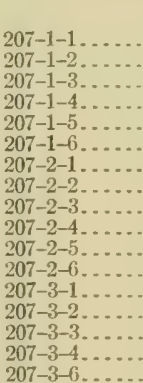 & $\begin{array}{r}\text { Per cent. } \\
70.33 \\
73.73 \\
70.26 \\
72.58 \\
73.70 \\
72.12 \\
66.78 \\
72.20 \\
67.96 \\
71.60 \\
78.26 \\
71.36 \\
64.43 \\
64.77 \\
73.45 \\
66.02 \\
67.17\end{array}$ & $\begin{array}{r}\text { Per cent. } \\
\text { 4. } 09 \\
5.89 \\
4.57 \\
6.30 \\
6.27 \\
5.42 \\
5.23 \\
5.89 \\
5.35 \\
6.33 \\
6.65 \\
5.89 \\
5.05 \\
3.78 \\
6.88 \\
5.27 \\
5.24\end{array}$ & $\begin{array}{r}\text { Per cent. } \\
13.79 \\
22.46 \\
15.37 \\
22.99 \\
23.84 \\
19.44 \\
15.74 \\
21.19 \\
16.72 \\
22.29 \\
30.59 \\
20.57 \\
14.21 \\
10.73 \\
25.91 \\
21.98 \\
15.96\end{array}$ & 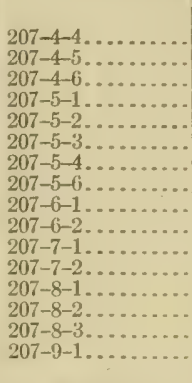 & $\begin{array}{r}\text { Per cent. } \\
77.53 \\
70.92 \\
71.00 \\
74.71 \\
70.44 \\
67.48 \\
79.22 \\
72.96 \\
82.37 \\
77.40 \\
70.66 \\
69.10 \\
75.41 \\
76.20 \\
72.32 \\
76.90 \\
\end{array}$ & $\begin{array}{r}\text { Per cent. } \\
6.63 \\
6.17 \\
6.20 \\
5.72 \\
5.28 \\
6.96 \\
5.16 \\
5.78 \\
5.32 \\
6.63 \\
4.70 \\
4.46 \\
6.58 \\
4.98 \\
4.59 \\
6.12\end{array}$ & $\begin{array}{c}\text { Per cent, } \\
29.51 \\
21.14 \\
21.38 \\
22.62 \\
17.86 \\
21.40 \\
24.83 \\
21.38 \\
30.18 \\
29.34 \\
16.02 \\
14.43 \\
26.76 \\
20.92 \\
16.58 \\
26.49\end{array}$ \\
\hline $\begin{array}{l}207-4-1 \ldots \ldots \\
207-4-2 \ldots \ldots \\
207-4-3 . \ldots\end{array}$ & $\begin{array}{l}71.75 \\
66.80 \\
68.01\end{array}$ & $\begin{array}{l}\text { 7. } 08 \\
5.94 \\
5.21\end{array}$ & $\begin{array}{l}25.06 \\
17.89 \\
16.29\end{array}$ & $\begin{array}{l}\text { Maximum... } \\
\text { Minimum... } \\
\text { Average.... }\end{array}$ & $\begin{array}{l}82.37 \\
64.43 \\
71.88\end{array}$ & $\begin{array}{l}7.08 \\
3.78 \\
5.66\end{array}$ & $\begin{array}{l}30.59 \\
13.79 \\
20.94\end{array}$ \\
\hline
\end{tabular}

This crop was harrested about September 25. While the sugar content is not so high as in 1905, yet the Maine station stands first in this respect, having a little higher percentage than the South Carolina station.

\section{GENERAL DISCUSSION OF DATA.}

Again South Carolina decidedly leads as to sugar content, having about the same as Maine $f_{(r}$ the Crosby variety, 20.64, as compared with 20.94; and 18.07 per cent for the Stowell, Connecticut standing second with 15.10 per cent. For the Stowell Evergreen variety the Florida and Maryland stations show about the same figures, namely, 13.94 and 13.87 per cent, respectively, while for the Crosby corn the Connecticut station stands last with 12.46 per cent, the Maryland and Florida stations ranking third and fourth, respectirely (17.46 and 15.64 per cent). Figure 2 presents these data graphically, together with the data for temperature, altitude, and arerage length of day at the several stations.

In 1905 the Stowell Evergreen corn grown in New Jersey was very much lower in sugar content than that from any other station, namely, 14 per cent; Connecticut, which stood next, having over 21 
per cent; while the lowest percentage of sugar in the Crosby corn was above 30 per cent and was found at the Connecticut station. The data for 1906 show a decrease in every case in sugar content, varying from 7 per cent in the case of the Stowell Evergreen grown at Connecticut to 18 per cent in the case of the Crosby, other decreases amounting to $10,11,13$, and 15 per cent. Unfortunately the experiment at the New Jersey station was abandoned, so no direct comparison can be made. In 1906, however, there is only one case (South Carolina, with 18.07 per cent) in which the sugar content of the Stowell Evergreen corn is appreciably above the lowest average for

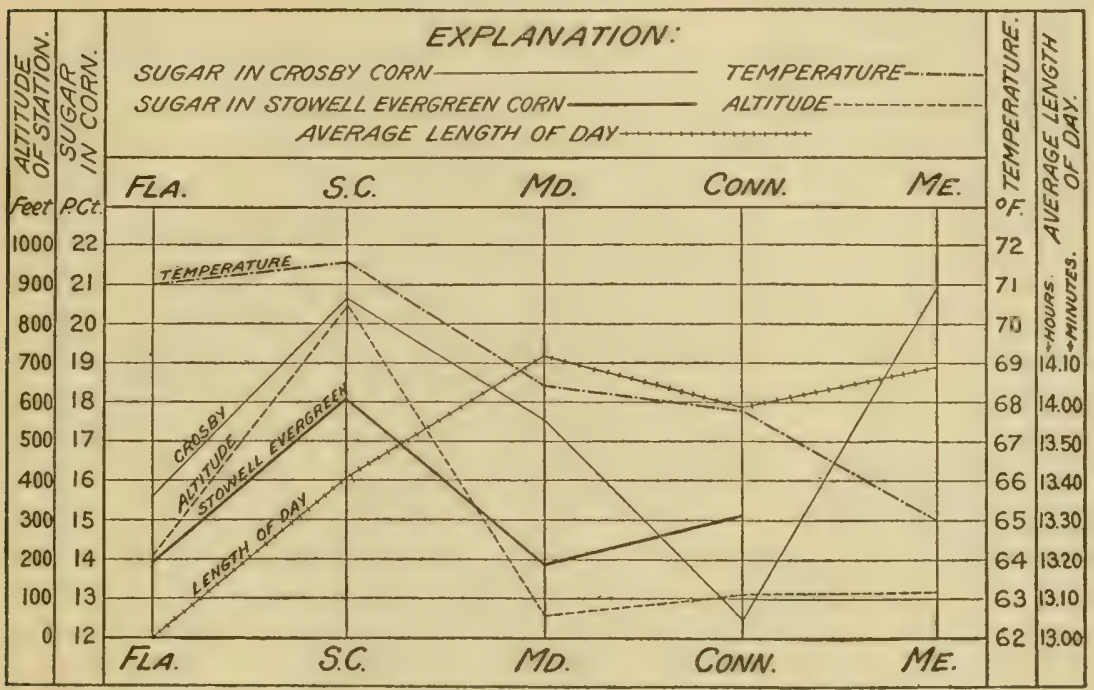

FIG. 2.-Percentage of sugar in the corn, temperature, altitude, and average length of day at the different stations, 1906.

1905-that of New Jersey. The 1906 minimum for the Crosby corn, always rich in sugar (12.46 per cent at the Connecticut station), is 2 per cent lower than the minimum for the Stowell Evergreen variety at New Jersey in 1905.

The average meteorological data for the two years do not throw much light on the marked inferiority of the $1906 \mathrm{crop}$, and it seems probable that it is the distribution of the sunshine and rainfall rather than the total amounts thereof (provided these do not exceed or fall below certain limits) which determine the quality of this crop. (See comparison of data for 1906 and 1907.) 
SUMMARY OF AVERAGE DATA FOR 1906.

Analytical data for Crosby and Stowell Evergreen corn, 1906, for five stations.

\begin{tabular}{|c|c|c|c|c|c|c|}
\hline \multirow{4}{*}{ Station. } & \multicolumn{6}{|c|}{ Variety of corn. } \\
\hline & \multicolumn{3}{|c|}{ Crosby. } & \multicolumn{3}{|c|}{ Stowell Evergreen. } \\
\hline & \multirow[b]{2}{*}{ Moisture. } & \multicolumn{2}{|c|}{ Total sugars. } & \multirow[b]{2}{*}{ Moisture. } & \multicolumn{2}{|c|}{ Total sugars. } \\
\hline & & $\begin{array}{l}\text { Original } \\
\text { sample. }\end{array}$ & $\begin{array}{c}\text { Calcu- } \\
\text { lated to } \\
\text { water-free } \\
\text { basis. }\end{array}$ & & $\mid \begin{array}{c}\text { Original } \\
\text { sample. }\end{array}$ & $\begin{array}{c}\text { Calcu- } \\
\text { lated to } \\
\text { water-free } \\
\text { basis. }\end{array}$ \\
\hline $\begin{array}{l}\text { Lake City, Fla.......... } \\
\text { Clemson College, S. C... } \\
\text { College Park, Md....... } \\
\text { New Haven, Conn....... } \\
\text { Orono, Me................ }\end{array}$ & \begin{tabular}{|r} 
Per cent. \\
67.11 \\
76.77 \\
69.79 \\
65.26 \\
71.88
\end{tabular} & \begin{tabular}{|r|} 
Per cent. \\
5.01 \\
4.73 \\
5.01 \\
4.23 \\
5.66
\end{tabular} & $\begin{array}{r}\text { Per cent. } \\
15.64 \\
20.64 \\
17.46 \\
12.46 \\
20.94\end{array}$ & $\begin{array}{r}\text { Per cent. } \\
70.27 \\
71.72 \\
72.34 \\
73.38 \\
\ldots . . .\end{array}$ & $\begin{array}{r}\text { Per cent. } \\
4.07 \\
4.99 \\
3.77 \\
3.92\end{array}$ & $\begin{array}{r}\text { Per cent. } \\
13.94 \\
18.07 \\
13.87 \\
15.10\end{array}$ \\
\hline
\end{tabular}

infeteorological data, 1906.

\begin{tabular}{|c|c|c|c|c|c|c|}
\hline Station. & $\begin{array}{l}\text { Temper- } \\
\text { ature. }\end{array}$ & $\begin{array}{l}\text { Precipi- } \\
\text { tation. }\end{array}$ & $\begin{array}{l}\text { Clear } \\
\text { days. }\end{array}$ & $\begin{array}{l}\text { Cloudy } \\
\text { days. }\end{array}$ & $\begin{array}{l}\text { Partly } \\
\text { cloudy } \\
\text { days. }\end{array}$ & $\begin{array}{l}\text { Sun- } \\
\text { shine. }\end{array}$ \\
\hline 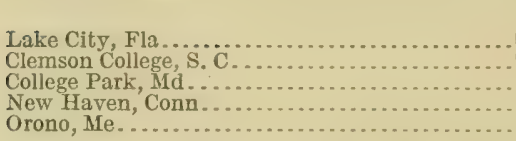 & $\begin{array}{l}{ }^{2} F . \\
71.0 \\
71.6 \\
68.4 \\
67.8 \\
65.0\end{array}$ & $\begin{array}{r}\text { Inches. } \\
22.66 \\
28.07 \\
28.88 \\
21.46 \\
8.53\end{array}$ & $\begin{array}{l}31 \\
67 \\
50 \\
56 \\
53\end{array}$ & $\begin{array}{l}41 \\
17 \\
33 \\
38 \\
38\end{array}$ & $\begin{array}{r}47 \\
38 \\
\ldots+\ldots \\
\cdots \\
\cdots\end{array}$ & $\begin{array}{r}\text { Percent. } \\
a 62 \\
60 \\
53 \\
55 \\
.\end{array}$ \\
\hline
\end{tabular}

a Sunshine data for nearest station making this record, i. e., Jacksonville.

\section{INVESTIGATION OF 1907}

INTRODUCTION.

The experimental work on the effect of environment on sugar corn was continued in 1907 in the same manner as during the two years previous, the same stations collaborating, viz, Florida, South Carolina, Maryland, Connecticut, and Maine. A record of cultural and meteorological data was kept as before, and at the proper time analyses of the edible corn were made at the different stations.

\section{FLORIDA.}

As the Florida experiment station was moved from Lake City to Gainesville in the fall of 1906 the corn for the investigation of 1907 was planted in a somewhat different type of soil. However, this is the only variation, as the climate and other conditions were about the same. The corn was planted March 14 and came up in about ten days, producing a very good stand. Commercial fertilizer was sown in the rows with the seed, these rows being opened with a nlow. The sced was not covered deep. 
The yield was satisfactory, but some difliculty was encountered in securing seed for the next season, owing to the ravages of raceons. The corn in the edible stage was sweet and tender, and was not attacked by weevils, as was the case at Lake City in 1906 .

The following table gives the climatic conditions under which the corn was grown:

Meteorological data for Gainesville, Fla., $190 \%$.

\begin{tabular}{|c|c|c|c|c|c|c|c|}
\hline Month. & $\begin{array}{l}\text { Mean } \\
\text { temper- } \\
\text { ature. }\end{array}$ & $\begin{array}{l}\text { Precipi- } \\
\text { tation. }\end{array}$ & $\begin{array}{l}\text { Cleảr } \\
\text { days. }\end{array}$ & $\begin{array}{l}\text { Partly } \\
\text { cloudy. }\end{array}$ & $\begin{array}{l}\text { Cloudy } \\
\text { days. }\end{array}$ & $\begin{array}{l}\text { Num- } \\
\text { ber of } \\
\text { rains. }\end{array}$ & $\begin{array}{l}\text { Sun- } \\
\text { shine. }\end{array}$ \\
\hline 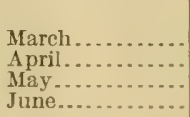 & $\begin{array}{c}{ }^{\circ} . \\
72.4 \\
66.3 \\
76.8 \\
80.6\end{array}$ & $\begin{array}{r}\text { Inches. } \\
0.32 \\
3.08 \\
3.91 \\
4.35\end{array}$ & $\begin{array}{l}18 \\
12 \\
21 \\
21\end{array}$ & $\begin{array}{l}2 \\
3 \\
4 \\
1\end{array}$ & $\begin{array}{r}11 \\
15 \\
6 \\
8\end{array}$ & $\begin{array}{r}2 \\
10 \\
11 \\
9\end{array}$ & $\begin{array}{r}\text { Per cent. } \\
79 \\
56 \\
69 \\
81\end{array}$ \\
\hline
\end{tabular}

The rainfall at Gainesville, Fla., was very evenly distributed during the growing season, and although the precipitation in March was small there appeared to be sufficient moisture for germination, as the plants came up quickly and a good stand was obtained. During the first two weeks of the period of development of the ear the rainfall was plentiful and frequent, while the last two weeks were dry, which would tend to produce a large yield and a sweet corn. The temperature during the months of April and May was favorable for the growth of the corn, which at the edible stage presented an unusually fine appearance. There were very many clear days, the percentage of sunshine being high in all the months except April.

Besides securing a good yield from both varieties, the sugar content of the corn was much higher this year than in 1906, a gain of 5 and 10 per cent, respectively, being recorded for the two varieties. The Stowell Evergreen corn had a high average content of sugar, namely, 24.25 per cent, though the minimum was as low as 10.33 per cent. The detailed analytical data follow:

Analysis of individual ears of Crosby corn grown at Gainesville, Fla., $190 \%$.

\begin{tabular}{|c|c|c|c|c|c|c|c|}
\hline Serial No. & Moisture. & $\begin{array}{l}\text { Total. } \\
\text { sugars. }\end{array}$ & \begin{tabular}{|c|} 
Sugars \\
calcula- \\
ted to \\
water-free \\
basis.
\end{tabular} & Serial No. & Moisture. & $\begin{array}{c}\text { Total } \\
\text { sugars. }\end{array}$ & $\begin{array}{l}\text { Sugars } \\
\text { calcula- } \\
\text { ted to } \\
\text { water-free } \\
\text { basis. }\end{array}$ \\
\hline 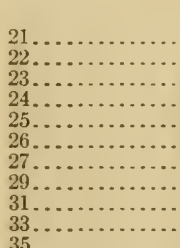 & $\begin{array}{r}\text { Per cent. } \\
71.96 \\
72.03 \\
69.88 \\
72.44 \\
70.90 \\
67.44 \\
79.28 \\
67.42 \\
69.87 \\
77.15 \\
77.90\end{array}$ & $\begin{array}{r}\text { Per cent. } \\
5.44 \\
5.34 \\
4.41 \\
5.28 \\
6.06 \\
5.83 \\
5.38 \\
5.17 \\
5.32 \\
5.42 \\
4.61\end{array}$ & $\begin{array}{r}\text { Per cent. } \\
19.40 \\
19.09 \\
14.64 \\
19.16 \\
20.83 \\
17.91 \\
25.97 \\
15.87 \\
17.66 \\
23.72\end{array}$ & 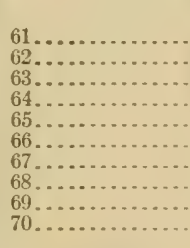 & $\begin{array}{r}\text { Per cent. } \\
75.60 \\
78.84 \\
64.78 \\
65.27 \\
78.19 \\
71.39 \\
80.24 \\
67.82 \\
78.29 \\
61.33\end{array}$ & $\begin{array}{r}\text { Per cent. } \\
6.63 \\
6.81 \\
5.71 \\
5.67 \\
6.27 \\
4.39 \\
7.20 \\
6.48 \\
7.35 \\
5.18\end{array}$ & $\begin{array}{c}\text { Per cent. } \\
27.17 \\
32.18 \\
16.18 \\
16.33 \\
28.75 \\
15.34 \\
36.44 \\
20.14 \\
33.86 \\
13.40\end{array}$ \\
\hline 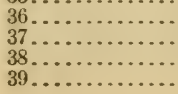 & $\begin{array}{l}71.72 \\
71.08 \\
68.87 \\
73.17\end{array}$ & $\begin{array}{r}\text { 5. } 25 \\
\text { 4. } 39 \\
5.59 \\
4.21\end{array}$ & $\begin{array}{l}18.57 \\
15.18 \\
17.96 \\
15.69\end{array}$ & $\begin{array}{l}\text { Maximum... } \\
\text { Minimum ... } \\
\text { Average..... }\end{array}$ & $\begin{array}{l}80.24 \\
61.33 \\
72.11\end{array}$ & $\begin{array}{l}7.35 \\
4.21 \\
5.57\end{array}$ & $\begin{array}{l}36.44 \\
13.40 \\
20.89\end{array}$ \\
\hline
\end{tabular}


Analysis of individual ears of Stowell Eiergreen corn grown at Gainesville, Fla., $190 \%$.

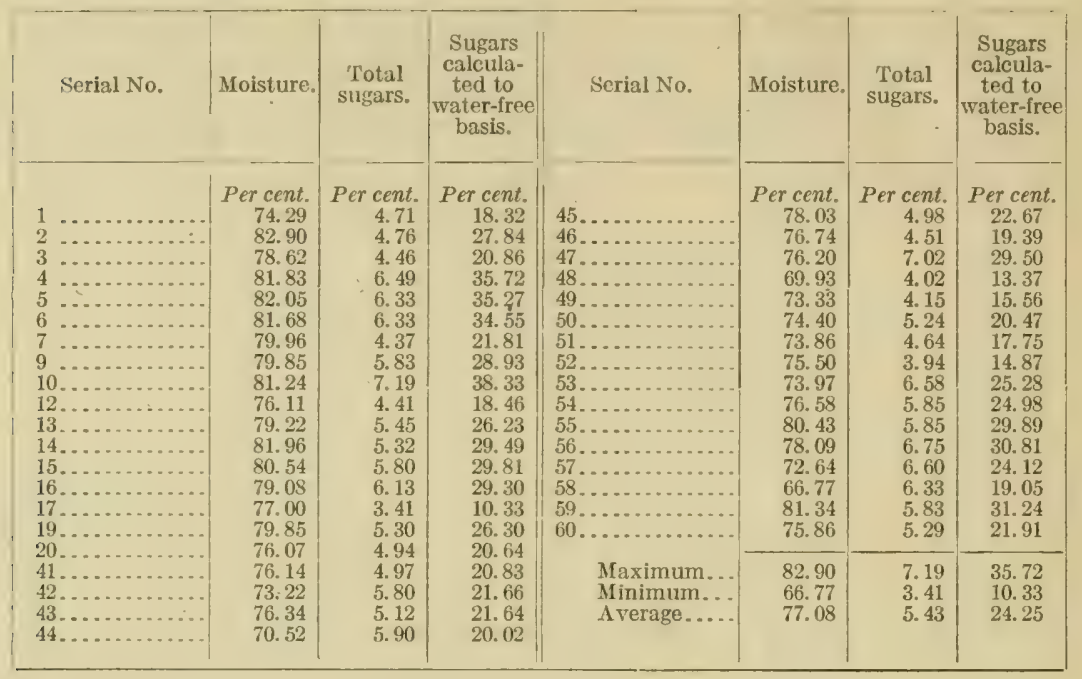

\section{SOUTH CAROLINA.}

The seed used for this planting at the South Carolina station was selected from the crop of 1906, grown at Clemson College, and was planted April 17, 1907, on a piece of new ground, sandy loam, which had been planted in upland rice in 1905 and in corn in 1906. In 1907 the soil was plowed to a depth of 8 inches and harrowed; then 200 pounds of 16 per cent acid phosphate, 100 pounds of kainit, and 200 pounds of cotton-seed meal to the acre were applied. The plants came up about April 30, and were cultivated after each rain with a cultivator. The Croshy corn was ready for table use about July 10, and the Stowell Evergreen July 16.

The Stowell Evergreen corn at the South Carolina station was the best for the three years in point of yield, stand, and physical appearance of the ears. The sugar content of the matured corn was not so high as that of Florida or Maryland, but the moisture was lower, and the sugars in the green corn as analyzed were higher than those at the Maryland station.

For the Crosby variety the average sugar content was higher than at any other station, and this has virtually been the case for three successive years, though Maine had about the same figure as South Carolina in 1906. Here the number of clear days is greater than at any other station. The rainfall, though very abundant during the early growing period, was only 2.22 inches in June and 2.41 inches in July; while in 1906, when the sugar content fell, there were 5.67 inches in June and 17.7 inches in July, with 1.5 rains during the latter month. The detailed meteorological and analytical data follow: 
Meteorological data for Clemson College, S. C., $190 \%$.

\begin{tabular}{|c|c|c|c|c|c|c|c|}
\hline Month. & $\begin{array}{l}\text { Mean } \\
\text { temper- } \\
\text { ature. }\end{array}$ & $\begin{array}{l}\text { I'recipi- } \\
\text { tation. }\end{array}$ & $\begin{array}{l}\text { Cleur } \\
\text { days. }\end{array}$ & $\begin{array}{l}\text { Partly } \\
\text { cloudy } \\
\text { days. }\end{array}$ & $\begin{array}{l}\text { Cloudy } \\
\text { days. }\end{array}$ & $\begin{array}{l}\text { Num- } \\
\text { ber of } \\
\text { rains. }\end{array}$ & $\begin{array}{l}\text { Sun- } \\
\text { shine. } a\end{array}$ \\
\hline 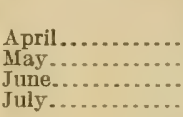 & $\begin{array}{l}{ }^{\circ} F . \\
54.8 \\
67.2 \\
73.0 \\
80.0\end{array}$ & $\begin{array}{r}\text { Inches. } \\
4.67 \\
4.29 \\
2.22 \\
2.41\end{array}$ & $\begin{array}{l}18 \\
19 \\
20 \\
24\end{array}$ & $\begin{array}{l}7 \\
5 \\
8 \\
6\end{array}$ & $\begin{array}{l}5 \\
7 \\
2 \\
1\end{array}$ & $\begin{array}{l}9 \\
9 \\
7 \\
8\end{array}$ & $\begin{array}{r}\text { Per cent. } \\
61 \\
55 \\
71 \\
74\end{array}$ \\
\hline
\end{tabular}

a Sunshine data taken at Atlanta, Ga.

Analysis of individual ears of Crosby corn grown at Clemson College, S. C., 1907.

\begin{tabular}{|c|c|c|c|c|c|c|c|}
\hline Serial No. & Moisture. & $\begin{array}{c}\text { Total } \\
\text { sugars. }\end{array}$ & $\begin{array}{c}\text { Sugars } \\
\text { calcula- } \\
\text { ted to } \\
\text { water-free } \\
\text { basis. }\end{array}$ & Serial No. & Moisture. & $\begin{array}{c}\text { Total } \\
\text { sugars. }\end{array}$ & $\begin{array}{l}\text { Sugars } \\
\text { calcula- } \\
\text { ted to } \\
\text { water-free } \\
\text { basis. }\end{array}$ \\
\hline $\begin{array}{l}300-1-1 \ldots \ldots . \\
300-1-2 \ldots \ldots . \\
300-2-1 \\
300-2-2 \\
300-3-1 \\
300 . \\
300 . \\
300-4-1 \\
300-4-2 \\
300-5-1\end{array}$ & $\begin{array}{r}\text { Per cent. } \\
79.93 \\
72.74 \\
71.94 \\
68.73 \\
68.94 \\
72.71 \\
69.50 \\
77.85 \\
69.06\end{array}$ & $\begin{array}{r}\text { Per cent. } \\
7.86 \\
6.36 \\
7.23 \\
6.58 \\
8.17 \\
7.49 \\
5.22 \\
6.36 \\
8.25\end{array}$ & \begin{tabular}{r|} 
Per cent. \\
39.16 \\
23.33 \\
25.77 \\
21.04 \\
26.31 \\
27.46 \\
17.12 \\
28.72 \\
26.67
\end{tabular} & 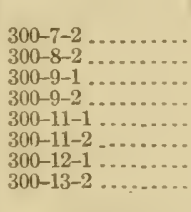 & \begin{tabular}{|r|} 
Per cent \\
81.26 \\
67.81 \\
74.66 \\
72.67 \\
72.08 \\
77.87 \\
71.79 \\
82.70
\end{tabular} & $\begin{array}{r}\text { Per cent. } \\
6.77 \\
7.62 \\
7.95 \\
7.26 \\
8.44 \\
5.37 \\
6.59 \\
5.79\end{array}$ & $\begin{array}{c}\text { Per cent. } \\
36.13 \\
23.67 \\
31.37 \\
26.57 \\
30.23 \\
24.27 \\
23.36 \\
33.47\end{array}$ \\
\hline $\begin{array}{l}300-5-2 \\
300-6-1 \\
300-6-2 \\
300-7-1 \ldots \ldots\end{array}$ & $\begin{array}{l}72.98 \\
77.84 \\
77.88 \\
78.67\end{array}$ & $\begin{array}{l}9.02 \\
7.54 \\
7.97 \\
8.57\end{array}$ & $\begin{array}{l}33.39 \\
34.03 \\
36.03 \\
40.18\end{array}$ & $\begin{array}{l}\text { Maximum.. } \\
\text { Minimum... } \\
\text { Average... }\end{array}$ & $\begin{array}{l}82.70 \\
67.81 \\
74.27\end{array}$ & $\begin{array}{l}9.02 \\
5.22 \\
7.25\end{array}$ & $\begin{array}{l}39.16 \\
17.12 \\
28.98\end{array}$ \\
\hline
\end{tabular}

Analysis of individual ears of Stowell Evergreen corn grown at Clemson College, S. C., $190 \%$.

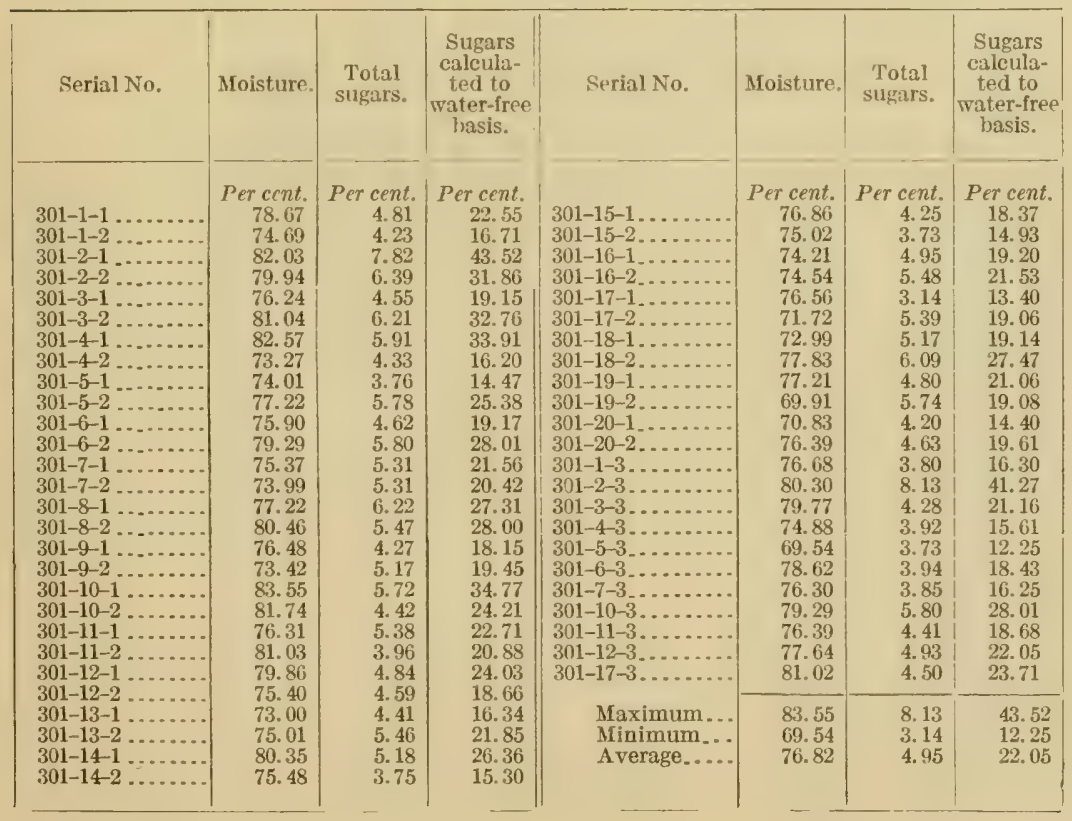


MARYLAND.

The seed used for planting at the Maryland station was selected from the 1906 crop. The soil was a sandy loam, which had been well limed the previous year, and had a crop of alfalfa grown on it. It was prepared by disking, harrowing, and pulverizing until in the best possible condition, and commercial fertilizer was sown in the rows.

The corn was planted about 4 inches deep, the rows being 3 feet 9 inches and the hills 15 inches apart. The crop came up well, but owing to the low temperature of May and June and the number of rains, the growth was very slow. When the corn was in edible condition, about August 15, there was a better stand than had been expected. The cultivation and fertilization were the same for the Crosby and Stowell Evergreen varieties. The Crosby corn reached the edible condition from August 7 to 12, and the Stowell Evergreen from August 19 to 22. The character of the season is shown by the following table:

Meteorological data for College Park, Md., $190 \%$.

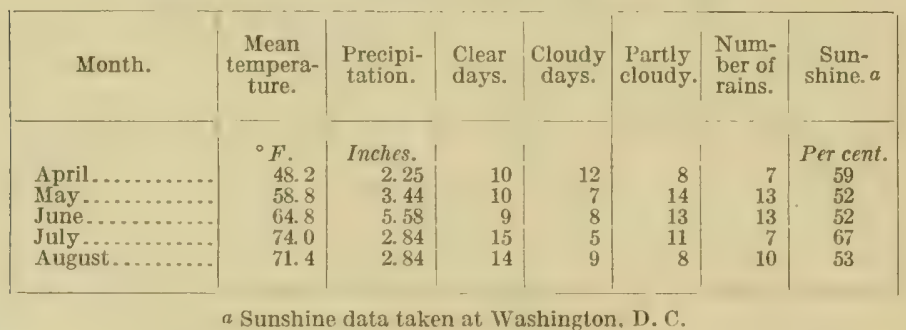

The mean teinperature at the Maryland station was very much below the arerage until July, the month when sugar is formed, when it increased to the normal figure, and the rainfall was nearly the same as that given for the South Carolina station for this month. The number of clear days is below the average, but the number of partly cloudy days is high and the sugar content is much greater in both varieties than in 1906 , amounting to 22.7 per cent for the Crosby and 25 per cent for the Stowell Evergreen. A wide rariation in sugar content is shown for both varieties, the maxima being 43.85 per cent for Crosby and 41.42 per cent for Stowell Evergreen, and the minima 11.16 and 15.21 , respectively. The detailed analytical data follow: 
Analysis of individual ears of Crosby corn grown at College Park, MId., $190 \%$.

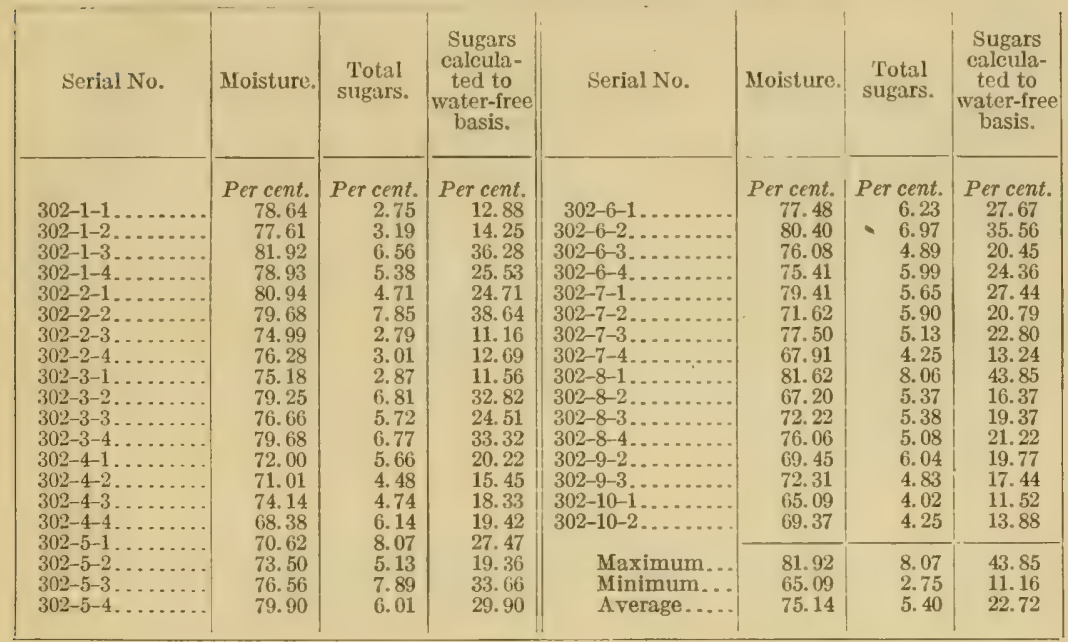

Analysis of individual eurs of Stowell Evergreen corn grown at College Park, Md., 1907.

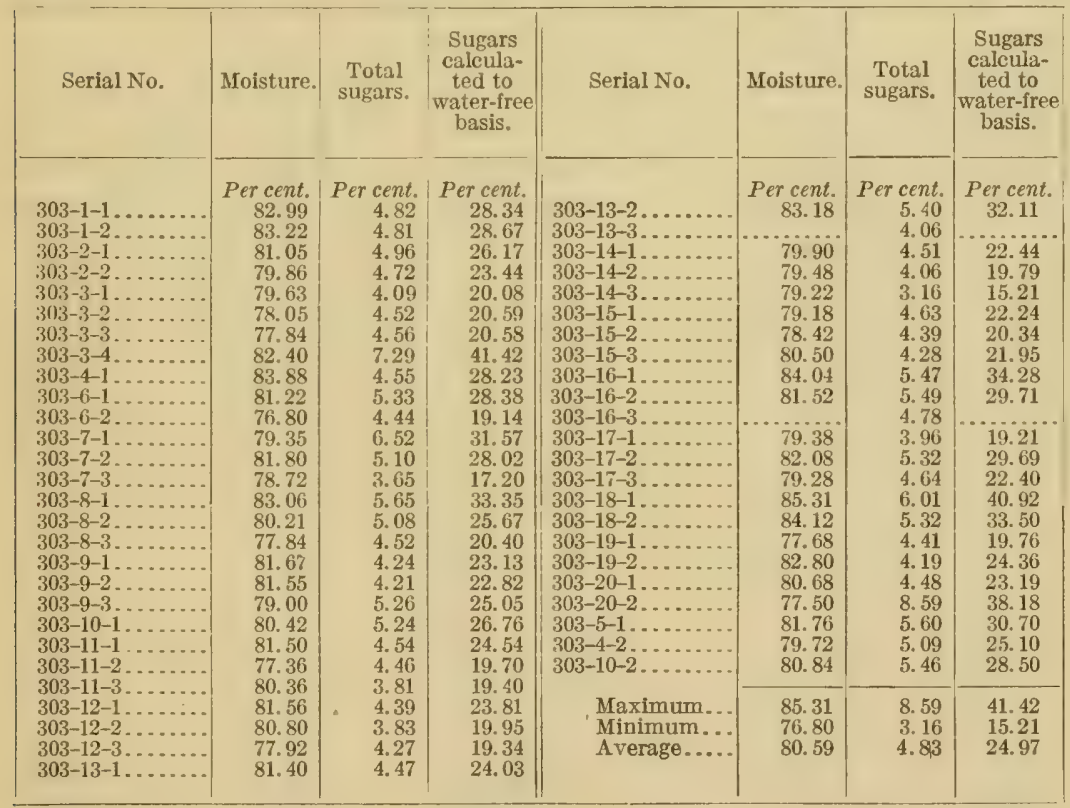

\section{CONNECTICUT.}

At Orange the corn was planted on May 28 and 29, 1907, on a sandy loam soil, which had been under cultivation and well fertilized for a number of years. Lima beans were grown on it in 1905 and tomatoes in 1906. Twelve tons per acre of stable manure, together with 600 pounds of 4-8-8 fertilizer, were used for the 1907 crop. 
The soil was plowed to a depth of about 5 inches, harrowed fine and smooth, marked with a shovel-nosed marker, and planted 4 inches deepr.

The corn was cultivated both ways four times from :3 to 4 inches deep with a one-horse cultivator, and required one hand weeding. It tasseled about August 5, the Crosby corn reaching the edible condition between September 3 and 7 , and the Stowell Evergreen between September 9 and 12.

The first frost occurred October 15, 1907, and a killing frost followed on October 21. The corn was completely ripened by October 22 and was harvested on October 23, 1907.

The meteorological data obtained at New Haven, Conn., are given in the following table:

Meteorological data for New Haven, Conn., 1907.

\begin{tabular}{|c|c|c|c|c|c|}
\hline Month. & $\begin{array}{c}\text { Mean } \\
\text { tempera- } \\
\text { ture. }\end{array}$ & $\begin{array}{l}\text { Precipi- } \\
\text { tation. }\end{array}$ & $\begin{array}{l}\text { Clear } \\
\text { days. }\end{array}$ & $\begin{array}{l}\text { Cloudy } \\
\text { days. }\end{array}$ & $\begin{array}{l}\text { Sun- } \\
\text { shine. }\end{array}$ \\
\hline $\begin{array}{l}\text { May........ } \\
\text { June........ } \\
\text { July....... } \\
\text { August ...... } \\
\text { September... }\end{array}$ & $\begin{array}{l}{ }^{\circ} F . \\
53 \\
64 \\
72 \\
69 \\
65\end{array}$ & $\begin{array}{r}\text { Inches. } \\
4.42 \\
3.18 \\
1.10 \\
1.21 \\
7.67\end{array}$ & $\begin{array}{r}9 \\
10 \\
16 \\
16 \\
9\end{array}$ & $\begin{array}{r}10 \\
7 \\
4 \\
5 \\
14\end{array}$ & $\begin{array}{r}\text { Per cent. } \\
52 \\
58 \\
71 \\
66 \\
39\end{array}$ \\
\hline
\end{tabular}

At the Connecticut station the rainfall was small during the growing season, being 1.10 inches for July and 1.21 inches for August, while during the harvesting season, September, it was excessive, attaining the high figure of 7.67 inches. The percentage of sunshine, as well as the mean temperature, were favorable to the growth of the plant, but at the time the sugars and starch were forming in the kernels the percentage of sunshine was very low, falling to 39 per cent for September. The percentage of sugars was 4.73 per cent ligher in the ('rosby and 2.01 per cent higher in the Stowell Evergreen than it was for the same varieties in 1906 . The detailed analytical data follow:

Analysis of individual ears of Crosby corn grown at Orange, Conn., 1907.

\begin{tabular}{|c|c|c|c|c|c|c|c|}
\hline Serial No. & Moisture. & $\begin{array}{c}\text { Total } \\
\text { sugars. }\end{array}$ & $\begin{array}{c}\text { Sugars } \\
\text { calculated } \\
\text { to water- } \\
\text { free basis. }\end{array}$ & Serial No. & Moisture. & $\begin{array}{c}\text { Total } \\
\text { sugars. }\end{array}$ & $\begin{array}{l}\text { Sugars } \\
\text { caleulated } \\
\text { to water- } \\
\text { free basis. }\end{array}$ \\
\hline $\begin{array}{l}305-1-2 \ldots \ldots \ldots \\
305-2-2 \ldots \ldots \ldots \\
305-3-1 \ldots \ldots \\
305-4-1 \ldots \ldots \\
305-4-2 \ldots \ldots \\
305-4-3 \ldots \ldots \ldots \\
305-5-2 \ldots \ldots \ldots \\
305-5-3 \ldots \ldots \\
305-6-1 \ldots \ldots \ldots \\
305-7-2 \ldots \ldots \ldots \\
305-8-1 \ldots \ldots \\
305-8-2 \ldots \ldots\end{array}$ & \begin{tabular}{|r} 
Per cent. \\
62.50 \\
70.22 \\
68.12 \\
64.94 \\
71.93 \\
71.60 \\
69.71 \\
70.68 \\
71.24 \\
73.30 \\
7468 \\
68.46
\end{tabular} & $\begin{array}{r}\text { Per cent. } \\
3.89 \\
3.47 \\
3.45 \\
5.08 \\
4.79 \\
5.61 \\
3.17 \\
5.61 \\
3.98 \\
5.63 \\
5.35 \\
5.06\end{array}$ & $\begin{array}{r}\text { Per cent. } \\
10.37 \\
11.65 \\
10.83 \\
14.49 \\
17.06 \\
19.75 \\
10.46 \\
19.15 \\
13.84 \\
21.09 \\
21.13 \\
16.04\end{array}$ & 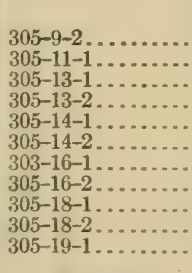 & \begin{tabular}{|r} 
Per cent. \\
77.88 \\
69.02 \\
75.78 \\
73.04 \\
70.96 \\
67.10 \\
67.28 \\
74.04 \\
79.63 \\
72.38 \\
72.38
\end{tabular} & $\begin{array}{r}\text { Per cent. } \\
5.85 \\
5.43 \\
4.95 \\
5.17 \\
5.28 \\
5.15 \\
5.21 \\
5.06 \\
4.42 \\
5.23 \\
4.38\end{array}$ & $\begin{array}{c}\text { Per cent. } \\
26.40 \\
17.53 \\
20.43 \\
19.18 \\
18.18 \\
15.65 \\
15.93 \\
19.49 \\
21.70 \\
18.94 \\
15.88\end{array}$ \\
\hline $\begin{array}{l}305-8-3 \ldots \ldots \ldots \\
305-8-4 \ldots \ldots \\
305-9-1 . \ldots\end{array}$ & $\begin{array}{l}72.68 \\
75.40 \\
66.24\end{array}$ & $\begin{array}{l}3.47 \\
5.98 \\
5.03\end{array}$ & $\begin{array}{r}12.72 \\
24.30 \\
14.90\end{array}$ & $\begin{array}{l}\text { Maximum... } \\
\text { Minimum... } \\
\text { Average..... }\end{array}$ & $\begin{array}{l}79.63 \\
62.50 \\
71.19\end{array}$ & $\begin{array}{l}5.98 \\
3.17 \\
4.83\end{array}$ & $\begin{array}{l}26.40 \\
10.37 \\
17.19\end{array}$ \\
\hline
\end{tabular}


Analysis of individual ears of Stowell Evergreen corn grown at Orange, Conn., 1907.

\begin{tabular}{|c|c|c|c|c|c|c|c|}
\hline Serial No. & Moisture. & $\begin{array}{c}\text { Total } \\
\text { sugars. }\end{array}$ & \begin{tabular}{|} 
Sugars \\
calculated \\
to water- \\
free basis.
\end{tabular} & Serial No. & Moisture. & $\begin{array}{l}\text { Total } \\
\text { sugars. }\end{array}$ & $\begin{array}{l}\text { Sugars } \\
\text { calculated } \\
\text { to water- } \\
\text { free basis. }\end{array}$ \\
\hline $\begin{array}{l}306-1-2 \ldots \ldots . \\
306-1-3 \ldots \ldots . \\
306-2-1 \ldots \ldots . \\
306-2-3 \ldots \ldots \\
306-8-3 \ldots \ldots . \\
306-9-1 \ldots \ldots . \\
306-9-2 \ldots \ldots . \\
306-9-3 \ldots \ldots . \\
306-10-1 \ldots \ldots . \\
306-10-2 \ldots \ldots . \\
306-10-3\end{array}$ & $\begin{array}{r}\text { Per cent. } \\
78.82 \\
78.56 \\
83.12 \\
775.68 \\
80.45 \\
79.28 \\
77.95 \\
72.86 \\
78.88 \\
73.44\end{array}$ & $\begin{array}{r}\text { Per cent. } \\
4.85 \\
4.39 \\
4.73 \\
5.19 \\
3.45 \\
3.15 \\
3.13 \\
3.31 \\
3.43 \\
3.80 \\
2.89\end{array}$ & $\begin{array}{r}\text { Per cent. } \\
22.90 \\
20.52 \\
28.04 \\
\cdots 1 . .28 \\
16.14 \\
15.12 \\
15.02 \\
12.65 \\
17.98 \\
10.88\end{array}$ & 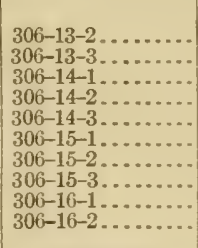 & $\begin{array}{r}\text { Per cent. } \\
81.70 \\
75.32 \\
77.68 \\
79.72 \\
78.82 \\
81.42 \\
79.16 \\
73.64 \\
76.89 \\
74.82\end{array}$ & $\begin{array}{r}\text { Per cent. } \\
3.97 \\
3.13 \\
3.13 \\
4.29 \\
2.99 \\
3.77 \\
5.07 \\
1.95 \\
3.51 \\
3.78\end{array}$ & $\begin{array}{c}\text { Per cent. } \\
21.69 \\
12.68 \\
14.05 \\
21.16 \\
14.08 \\
20.30 \\
24.34 \\
7.39 \\
15.17 \\
15.01\end{array}$ \\
\hline $\begin{array}{l}300-11-3 . \ldots \ldots \\
306-12-1 . \ldots . \\
306-13-1 . . .\end{array}$ & $\begin{array}{l}80.39 \\
79.30 \\
80.82\end{array}$ & $\begin{array}{l}3.53 \\
3.07 \\
4.08\end{array}$ & $\begin{array}{l}10.00 \\
18.00 \\
14.83 \\
21.28\end{array}$ & $\begin{array}{l}\text { Maximum... } \\
\text { Minimum... } \\
\text { Average.... . }\end{array}$ & $\begin{array}{l}83.12 \\
72.86 \\
78.20\end{array}$ & $\begin{array}{l}5.19 \\
2.89 \\
3.69\end{array}$ & $\begin{array}{r}28.04 \\
7.39 \\
17.11\end{array}$ \\
\hline
\end{tabular}

\section{MAINE.}

The Crosby corn grown at the Maine station did not reach the edible condition before the first frost, and as the samples secured were extremely young, their analyses will not be comparable with those made at other places. The corn was planted June 25 on a clay-loam soil which had been used by the horticultural department of the station for growing small fruits and garden crops, beets being the previous crop grown, on which 800 pounds of commercial fertilizer had been used. In 1907 the soil was plowed to a depth of 7 inches, harrowed twice with a disk and three times with a smoothing harrow, and 800 pounds of fertilizer were then sown broadcast. The corn was cultivated with a horse cultivator five times and hoed twice.

The meteorological data were favorable to a high sugar content; a heavy rainfall, 5.77 inches, occurred in June and 3.44 inches in July, the time of germination and early growth at the Maine station, and very little rain fell in August (1.41 inches), thus favoring the storage of sugar.

Meteorological data for Orono, Me., 1907.

\begin{tabular}{|c|c|c|c|c|c|}
\hline Month. & $\begin{array}{l}\text { Mean } \\
\text { tempera- } \\
\text { ture. }\end{array}$ & $\begin{array}{c}\text { Precipi- } \\
\text { tation. }\end{array}$ & $\begin{array}{l}\text { Clear } \\
\text { days. }\end{array}$ & $\begin{array}{l}\text { Partly } \\
\text { cloudy. }\end{array}$ & $\begin{array}{l}\text { Cloudy } \\
\text { days. }\end{array}$ \\
\hline June. & ${ }^{\circ}{ }^{F}$. & $\begin{array}{l}\text { Inches. } \\
5.77\end{array}$ & 10 & 5 & 15 \\
\hline July.. & 66.8 & 3.44 & 10 & 10 & 11 \\
\hline August. - & 65.2 & 1.41 & 11 & 11 & 9 \\
\hline Septembe & 59.4 & 6.12 & 6 & 11 & 12 \\
\hline
\end{tabular}

The data for the Maine station are given for reference and comparison, but are not platted with the other stations in the graphic charts for the reason previously given. Attention is called to the high percentages of sugar found, notwithstanding the immaturity of the samples; and this is of special interest when considered in connection with the 1905 data for the Crosby. During that year the sugar content for the Crosby variety was also very high, and the corn was not as young as the Maine samples for 1907. 
Analysis of individual ears of Crosby corn grown at Orono, Me., $190 \%$.

\begin{tabular}{|c|c|c|c|c|c|c|c|}
\hline Serial No. & Moisture. & $\begin{array}{c}\text { Total } \\
\text { sugars. }\end{array}$ & $\begin{array}{c}\text { Sugars } \\
\text { calculated } \\
\text { to water- } \\
\text { free basis. }\end{array}$ & Serial No. & Moisture. & $\begin{array}{c}\text { Total } \\
\text { sugars. }\end{array}$ & $\begin{array}{l}\text { Sugars } \\
\text { calculated } \\
\text { to water- } \\
\text { free basis. }\end{array}$ \\
\hline & \multirow{2}{*}{$\begin{array}{r}\text { Per cent. } \\
83.32 \\
80.50 \\
77.75 \\
80.85 \\
76.77 \\
75.32 \\
82.06 \\
79.18 \\
80.72 \\
82.31\end{array}$} & \multirow{2}{*}{$\begin{array}{r}\text { Per cent. } \\
8.18 \\
8.27 \\
8.92 \\
8.72 \\
8.90 \\
8.08 \\
8.92 \\
9.00 \\
7.92 \\
8.97\end{array}$} & \multirow{2}{*}{\begin{tabular}{r|} 
Per cent. \\
49.04 \\
42.41 \\
40.09 \\
45.54 \\
38.31 \\
32.74 \\
49.72 \\
43.23 \\
41.08 \\
50.70
\end{tabular}} & \multirow{2}{*}{ 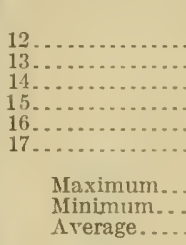 } & \begin{tabular}{|r} 
Per cent. \\
81.41 \\
77.42 \\
75.51 \\
82.58 \\
82.74 \\
81.68
\end{tabular} & $\begin{array}{r}\text { Per cent. } \\
9.01 \\
6.69 \\
6.99 \\
7.86 \\
7.57 \\
9.12\end{array}$ & $\left\{\begin{array}{c}\text { Per cent. } \\
48.47 \\
29.63 \\
28.54 \\
45.12 \\
43.86 \\
49.78\end{array}\right.$ \\
\hline & & & & & $\begin{array}{l}83.32 \\
75.32 \\
80.01\end{array}$ & $\begin{array}{l}9.12 \\
6.69 \\
8.32\end{array}$ & $\begin{array}{l}50.70 \\
28.54 \\
42.39\end{array}$ \\
\hline
\end{tabular}

GENERAL DISCUSSION OF DATA.

The results of the investigation in 1907 are platted graphically in figure 3 , showing the percentage of sugars in the two varieties of corn, altitude of stations, temperature, and average length of day.

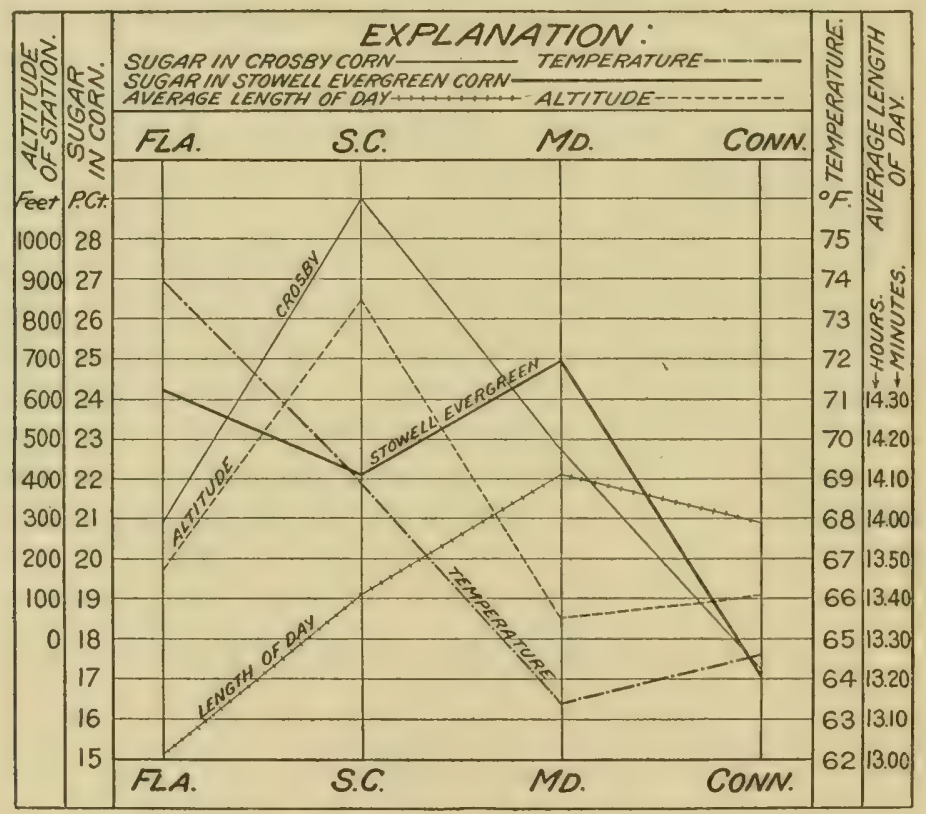

FIG. 3.-Percentage of sugar in the corn, temperature, altitude, and average length of day at the different stations, 1907.

For the third time the South Carolina station produced the Crosby corn with the highest percentage of sugar; but a higher percentage of sugar was found in the Stowell Evergreen at both the Florida and Maryland stations, although the two previous years the South Carolina station led for both. The sunshine data follow in a general way those of 1905 and 1906, Maryland having the lowest percentage, with Comnecticut only slightly higher, while South Carolina and Florida 
have the greatest amounts. The percentage of sunshine is higher at every station than it was in 1906, and with one exception, Connecticut, it is higher than in 1905 also. The distribution of sunshine shows a greater number of clear days than was found in either of the previous years, with the exception of MIaryland, where the greatest percentage occurred in 1905.

The percentage of sugar and the temperature curves follow in general the lines of the other years except in the case of the Maryland station, where the temperature is lower than at the Connecticut station.

SUMMARY OF AVERAGE DATA FOR 1907.

Analytical data for Crosby and Stowell Evergreen corn grown at four stations, 1907.

\begin{tabular}{|c|c|c|c|c|c|c|}
\hline \multirow{4}{*}{ Station. } & \multicolumn{6}{|c|}{ Variety of corn. } \\
\hline & \multicolumn{3}{|c|}{ Crosby. } & \multicolumn{3}{|c|}{ Stowell Evergreen. } \\
\hline & \multicolumn{3}{|c|}{ Total sugars. } & \multirow[b]{2}{*}{ Moisture. } & \multicolumn{2}{|c|}{ 'Total sugars. } \\
\hline & Moisture. & $\begin{array}{l}\text { Edible } \\
\text { condi- } \\
\text { tion. }\end{array}$ & $\begin{array}{l}\text { Calcu- } \\
\text { Iated to } \\
\text { water- } \\
\text { free } \\
\text { basis. }\end{array}$ & & $\begin{array}{l}\text { Edible } \\
\text { condi- } \\
\text { tion. }\end{array}$ & $\begin{array}{l}\text { Calcu- } \\
\text { lated to } \\
\text { water- } \\
\text { free } \\
\text { basis. }\end{array}$ \\
\hline $\begin{array}{l}\text { Gainesville, Fla } \\
\text { Clemson College, S. } \\
\text { College Park, Md........ } \\
\text { New IIaven, Conn ....... }\end{array}$ & $\begin{array}{r}\text { Per cent. } \\
72.11 \\
74.27 \\
75.14 \\
71.19\end{array}$ & $\begin{array}{r}\text { Per cent. } \\
5.57 \\
7.25 \\
5.40 \\
4.83\end{array}$ & $\begin{array}{r}\text { Per cent. } \\
20.89 \\
28.98 \\
22.72 \\
17.19\end{array}$ & \begin{tabular}{r|} 
Per cent. \\
$7 \% .08$ \\
76.82 \\
80.59 \\
78.20
\end{tabular} & $\begin{array}{r}\text { Per cent. } \\
5.43 \\
4.95 \\
4.83 \\
3.69\end{array}$ & $\begin{array}{r}\text { Per cent. } \\
24.25 \\
22.05 \\
24.97 \\
17.11\end{array}$ \\
\hline
\end{tabular}

Meteorological data, Ifarch to September, 1907, at five stations.

\begin{tabular}{|c|c|c|c|c|c|c|}
\hline Station. & $\begin{array}{l}\text { Tempera- } \\
\text { tation. }\end{array}$ & $\begin{array}{l}\text { Precipi- } \\
\text { tation. }\end{array}$ & $\begin{array}{l}\text { Clear } \\
\text { days. }\end{array}$ & $\begin{array}{l}\text { Cloudy } \\
\text { days. }\end{array}$ & $\begin{array}{l}\text { Partly } \\
\text { cioudy } \\
\text { days. }\end{array}$ & Sunshine. \\
\hline 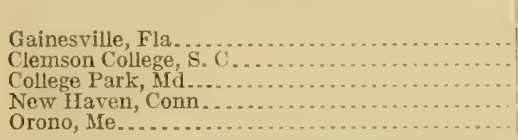 & \begin{tabular}{l|}
74.0 \\
68.7 \\
63.4 \\
64.6 \\
63.3
\end{tabular} & $\begin{array}{r}\text { Inches. } \\
11.66 \\
13.59 \\
16.95 \\
17.58 \\
16.74\end{array}$ & $\begin{array}{l}72 \\
81 \\
58 \\
60 \\
37\end{array}$ & $\begin{array}{l}40 \\
15 \\
41 \\
40 \\
47\end{array}$ & $\begin{array}{c}10 \\
26 \\
54 \\
37\end{array}$ & $\begin{array}{r}\text { Per cent. } \\
71.2 \\
a 65.2 \\
b 56.6 \\
57.2 \\
-. . .\end{array}$ \\
\hline
\end{tabular}

a l'er cent of sunshine given for Atlanta, Ga.

$b$ l'er cent of sunshine given for Washington, D. C.

\section{INVESTIGATION OF 1908.}

FLOIRIDA.

At the Florida station the Crosby corn was grown in sandy soil, the preceding crop having been sorghum. The ground was prepared by plowing to a depth of 4 to 6 inches with a two-horse plow and then harrowing with a smoothing liarrow. Fertilizer was applied in the form of barnyard manure, and the seed was planted by hand on 
March 11. The young plants appeared March 18 and were cultivated March 25 and April 3, 14, and 27, with a two-horse riding cultivator. The corn tasseled May 1, and reached the edible condition May 30, the matured corn being harvested July 1.

The plat of land deroted to the Stowell Evergreen corn was also of a sandy type, but had lain fallow the previous season. The ground was prepared in the same manner as that for the Crosby, and the dates of planting, appearance of young plants, and cultivation, as well as the methods of cultivation, were also the same. The first tassel appeared May 5, the corn being in full tassel May 16, and ready for table use June 1. The mature corn was harvested July 1.

The characteristics of the season are shown by the following meteorological data for the growing months:

Meteorological data for Gainesville, Fla., 1908.

\begin{tabular}{|c|c|c|c|c|c|c|}
\hline Month. & $\begin{array}{l}\text { Mean } \\
\text { temper- } \\
\text { ature. }\end{array}$ & $\begin{array}{l}\text { Total } \\
\text { precipi- } \\
\text { tation. }\end{array}$ & $\begin{array}{l}\text { Clear } \\
\text { days. }\end{array}$ & $\begin{array}{l}\text { Partly } \\
\text { cloudy } \\
\text { days. }\end{array}$ & $\begin{array}{l}\text { Cloudy } \\
\text { days. }\end{array}$ & $\begin{array}{l}\text { Num- } \\
\text { ber of } \\
\text { rains. }\end{array}$ \\
\hline $\begin{array}{l}\text { Mrarch.......... } \\
\text { April ........... } \\
\text { May ........... } \\
\text { June......... }\end{array}$ & $\begin{array}{l}\circ F \\
69.0 \\
76.1 \\
75.9 \\
79.2\end{array}$ & $\begin{array}{r}\text { Inches. } \\
0.16 \\
1.66 \\
1.78 \\
8.95\end{array}$ & $\begin{array}{l}25 \\
26 \\
15\end{array}$ & $\begin{array}{l}0 \\
1 \\
5\end{array}$ & $\begin{array}{r}5 \\
4 \\
10\end{array}$ & $\begin{array}{r}2 \\
5 \\
7 \\
17\end{array}$ \\
\hline
\end{tabular}

For a period of thirteen days just previous to the harvesting of the corn no rain fell, but two days before work began a rainfall of 1.45 inches was recorded, and during the time of harvesting four rains occurred. The analysis of the crop gave the following data:

Analysis of individual eurs of Crosby corn grown at Gainesville, F'la., 1908.

\begin{tabular}{|c|c|c|c|}
\hline Serial No. & Moisture. & $\begin{array}{c}\text { Total } \\
\text { sugars, } \\
\text { edible } \\
\text { condition. }\end{array}$ & $\begin{array}{c}\text { Total } \\
\text { sugars cal } \\
\text { culated to } \\
\text { water-free } \\
\text { basis. }\end{array}$ \\
\hline & $\begin{array}{r}\text { Pcrcent. } \\
69.71 \\
72.06 \\
67.81 \\
61.99\end{array}$ & $\begin{array}{r}\text { Per cent. } \\
5.59 \\
4.69 \\
5.38 \\
4.30\end{array}$ & $\begin{array}{r}\text { Per cent. } \\
18.46 \\
16.79 \\
16.71 \\
11.02\end{array}$ \\
\hline $\begin{array}{l}\text { Maximum } \\
\text { Minimum. } \\
\text { Average.. }\end{array}$ & $\begin{array}{l}72.06 \\
61.99 \\
67.89\end{array}$ & $\begin{array}{l}5.59 \\
4.30 \\
4.99\end{array}$ & $\begin{array}{l}18.46 \\
11.02 \\
15.74\end{array}$ \\
\hline
\end{tabular}


Analysis of individual ears of Stowell Evergreen corn grown at Gainesville, Fla., 1908.

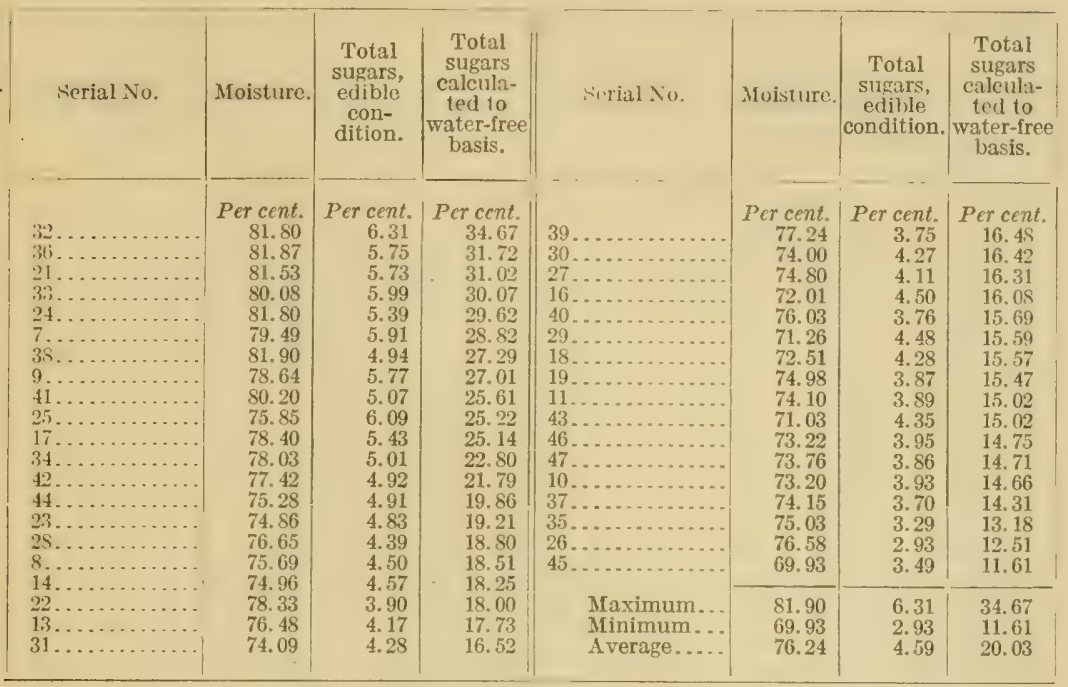

Although only a few samples of Crosby corn were analyzed, each one represents four ears of corn except No. 3, of which only one ear was used. Both the averages for moisture and for sugars are about the same as the figures obtained in 1906, but are lower than those for the preceding year. The stand of corn was also much poorer than in 1907.

The average sugar content of the Stowell Evergreen is above the average obtained for the Crosby, despite the fact that the latter is usually sweeter. While not so high as the average for 1907 , it is very much above that for the 1906 crop. In general quality the corn was also superior to the Crosby variety. The matured seeds were attacked by the weevil, and it will be difficult to secure seed for planting in 1909.

\section{SOUTH CAROLINA.}

At the South Carolina station the character of the soil used for the Crosby corn was a well-drained sandy loam. The land was prepared by plowing with a two-horse turning plow, after which it was harrowed with a disk plow. Fertilizer composed of 250 pounds of 14 per cent acid phosphate, 100 pounds of nitrate of soda, 225 pounds of cottonseed meal, and 320 pounds of kainit per acre was applied at the time of planting, April 22. A drouth in the early spring caused a poor stand. A weeder was used in the first cultivation and a plow cultivator in the three succeeding ones. The corn reached the edible state July 11.

The type of soil on which the Stowell Evergreen was grown was the same as that used for the Crosby variety, as were the method of preparing the ground, the character of the fertilization, and the dates of 4925-Bull. 127-09-4 
planting and cultivation. A good stand of Stowell Evergreen was obtained, but this was not the case with the Crosby. The edible condition was reached about July 23.

The average meteorological data for the months of the growing season are as follows:

Meteorological data for Clemson College, S. C., 1908.

\begin{tabular}{|c|c|c|c|c|c|c|}
\hline Month. & $\begin{array}{c}\text { Mean } \\
\text { tempera- } \\
\text { ture. }\end{array}$ & $\begin{array}{l}\text { Total } \\
\text { precipi- } \\
\text { tation. }\end{array}$ & $\begin{array}{l}\text { Clear } \\
\text { days. }\end{array}$ & $\begin{array}{l}\text { Partly } \\
\text { cloudy } \\
\text { days. }\end{array}$ & $\begin{array}{c}\text { Cloudy } \\
\text { days. }\end{array}$ & $\begin{array}{l}\text { Number } \\
\text { of rains. }\end{array}$ \\
\hline $\begin{array}{l}\text { Ipril .... } \\
\text { Mlay ..... } \\
\text { June ..... } \\
\text { July . . . . }\end{array}$ & $\begin{array}{l}{ }^{\circ} F \text {. } \\
64.0 \\
69.0 \\
74.3 \\
77.6\end{array}$ & $\begin{array}{r}\text { Inches. } \\
6.17 \\
1.58 \\
4.84 \\
6.64\end{array}$ & $\begin{array}{l}13 \\
21 \\
17 \\
22\end{array}$ & $\begin{array}{r}11 \\
8 \\
11 \\
5\end{array}$ & $\begin{array}{l}6 \\
2 \\
2 \\
4\end{array}$ & $\begin{array}{r}8 \\
3 \\
7 \\
11\end{array}$ \\
\hline
\end{tabular}

The rainfall for 1908 was very unevenly distributed. From June 23 to July 2 no rain fell. On the following dates the inches of rainfall were as indicated: July 2, 0.36 ; July 3, 0.20 ; July 4, 2.90; and July 5, 1.06. With the exception of a slight shower on the following day no further precipitation occurred until July 19. During this period, July 11 to 16, inclusive, the Crosby variety was harvested. On July $19,0.90$ inch fell, and the next rain recorded was on July 25, on which date the harvesting was finished.

The analytical data for the Crosby corn are as follows:

Analysis of individual ears of Crosby corn grown at Clemson College, S. C., 1908.

\begin{tabular}{|c|c|c|c|c|c|c|c|}
\hline Serlal No. & Moisture. & $\begin{array}{l}\text { Total } \\
\text { sugars, } \\
\text { edible } \\
\text { condi- } \\
\text { tion. }\end{array}$ & $\begin{array}{c}\text { Total } \\
\text { sugars } \\
\text { calcula- } \\
\text { ted to } \\
\text { water-free } \\
\text { basis. }\end{array}$ & Serial No. & Moisture. & $\begin{array}{l}\text { Total } \\
\text { sugars, } \\
\text { edible } \\
\text { condi- } \\
\text { tion. }\end{array}$ & $\begin{array}{c}\text { Total } \\
\text { sugars } \\
\text { calcula- } \\
\text { ted to } \\
\text { water-free } \\
\text { basis. }\end{array}$ \\
\hline 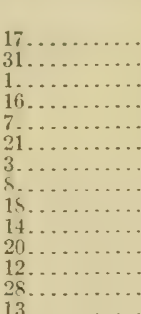 & $\begin{array}{r}\text { Per cent. } \\
81.85 \\
82.52 \\
83.64 \\
78.24 \\
82.34 \\
76.04 \\
79.52 \\
80.71 \\
78.48 \\
74.04 \\
84.97 \\
73.06 \\
77.28 \\
75.63\end{array}$ & $\begin{array}{r}\text { Per cent. } \\
7.11 \\
6.46 \\
6.03 \\
6.50 \\
5.25 \\
6.91 \\
5.81 \\
5.34 \\
5.84 \\
6.95 \\
3.98 \\
6.69 \\
5.33 \\
5.66\end{array}$ & \begin{tabular}{r|} 
Per cent. \\
39.18 \\
36.96 \\
36.86 \\
29.87 \\
29.73 \\
28.84 \\
28.37 \\
27.68 \\
27.14 \\
26.77 \\
26.48 \\
24.83 \\
23.46 \\
23.23
\end{tabular} & 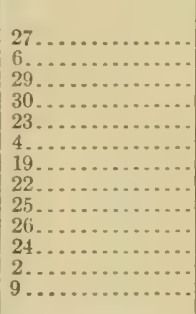 & $\begin{array}{r}\text { Per cent. } \\
76.53 \\
76.69 \\
74.50 \\
77.23 \\
77.61 \\
75.07 \\
74.91 \\
72.98 \\
76.26 \\
67.46 \\
70.54 \\
71.33 \\
71.35\end{array}$ & $\begin{array}{r}\text { Per cent. } \\
4.80 \\
4.57 \\
4.79 \\
4.23 \\
4.15 \\
4.36 \\
3.93 \\
3.94 \\
3.65 \\
4.89 \\
4.42 \\
4.27 \\
4.23\end{array}$ & $\begin{array}{c}\text { Per cent. } \\
20.45 \\
19.61 \\
18.79 \\
18.58 \\
18.53 \\
17.49 \\
15.66 \\
15.48 \\
15.37 \\
15.03 \\
15.00 \\
14.89 \\
14.77\end{array}$ \\
\hline $\begin{array}{l}32 \ldots \ldots \\
15 \ldots \ldots \\
10 \ldots \ldots \\
11 \ldots \ldots\end{array}$ & $\begin{array}{l}74.85 \\
76.72 \\
81.67 \\
73.21\end{array}$ & $\begin{array}{l}5.83 \\
5.26 \\
4.07 \\
5.69\end{array}$ & $\begin{array}{l}23.18 \\
22.60 \\
22.20 \\
21.16\end{array}$ & $\begin{array}{l}\text { Maximum... } \\
\text { Minimum... } \\
\text { Average.... }\end{array}$ & $\begin{array}{l}84.97 \\
70.54 \\
76.72\end{array}$ & $\begin{array}{l}7.11 \\
3.65 \\
5.19\end{array}$ & $\begin{array}{l}39.18 \\
14.77 \\
23.17\end{array}$ \\
\hline
\end{tabular}

The Crosby variety again showed a higher sugar content in South Carolina than at any other station. Here, as in Florida, a sweeter corn was produced in 1908 than in 1906, but the percentage of sugars was not so high as in 1907 . Although the stand was poor, a very fair-sized ear was grown and one which had a good flavor. The Stowell Evergreen yielded the following analytical results: 
Analysis of individual ears of Stowell Evergreen corn grown at Clemson College, S. C., 1908.

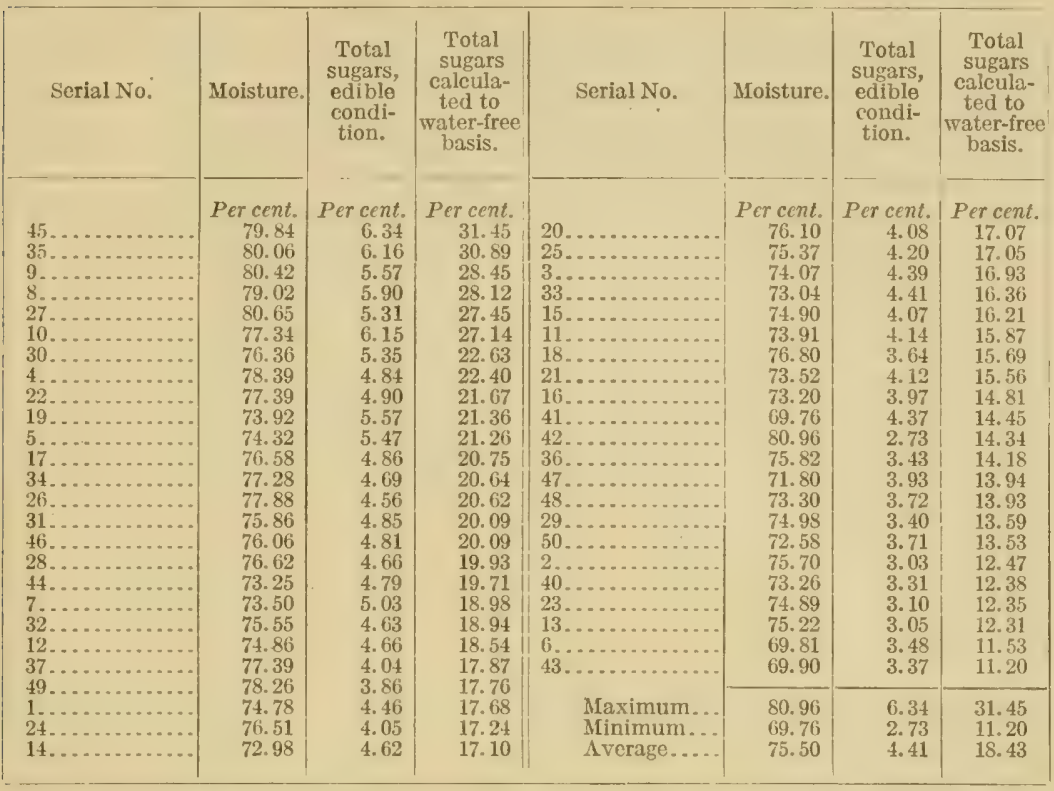

The Stowell Evergreen made a good physical development, being tender, well flavored, and producing fail-sized ear's, although worms were prevalent again this year.

\section{MARYLAND.}

The plat of ground assigned to the Crosby corn in 1908 at the Maryland station was a sandy loam which had lain idle the preceding year. The soil was prepared by plowing 6 inches deep and harrowing until it became smooth and fine. The plat had been previously well manured and this year was treated with mixed commercial fertilizer. The seed was planted May 28 by hand, the young plants came up June 8 , and were cultivated three or four times in the ordinary way and hoed twice. The climatic conditions for the growing season were as follows:

Meteorological data for College Park, MId., 1908.

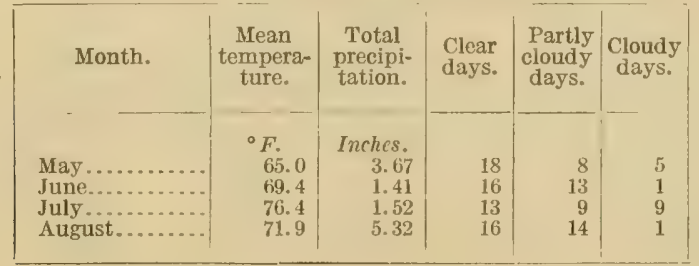


The total rainfall for August indicates an abundance of moisture, but the rains were not nearly so frequent as in the preceding years. On August 9, 0.85 inch of rain fell, and for nine days there was no rain, but at the end of that period there was a rainfall of 0.42 inch. On August 25 the precipitation was 0.2 inch and on August 27, 2.8 inches. The Crosby corn did not mature, and since the Stowell Evergreen was harvested from lugust 23 to 30 , it is quite evident that the last two rains did not affect the storage of sugars.

The land set aside for the Stowell Evergreen was of the same type as that used for the Crosby-that is, a sandy loam. Tomatoes were grown immediately preceding this crop. The preparation of the soil, character of the fertilization, date of the appearance of the young plants, and the date and manner of cultivation were the same as for the Crosby variety. The corn tasseled July 17 and was ready for table use about August 23.

The analytical data are as follows:

Analysis of individual ears of Stowell Evergreen corn grown at College P'ark, Ndd., 1908.

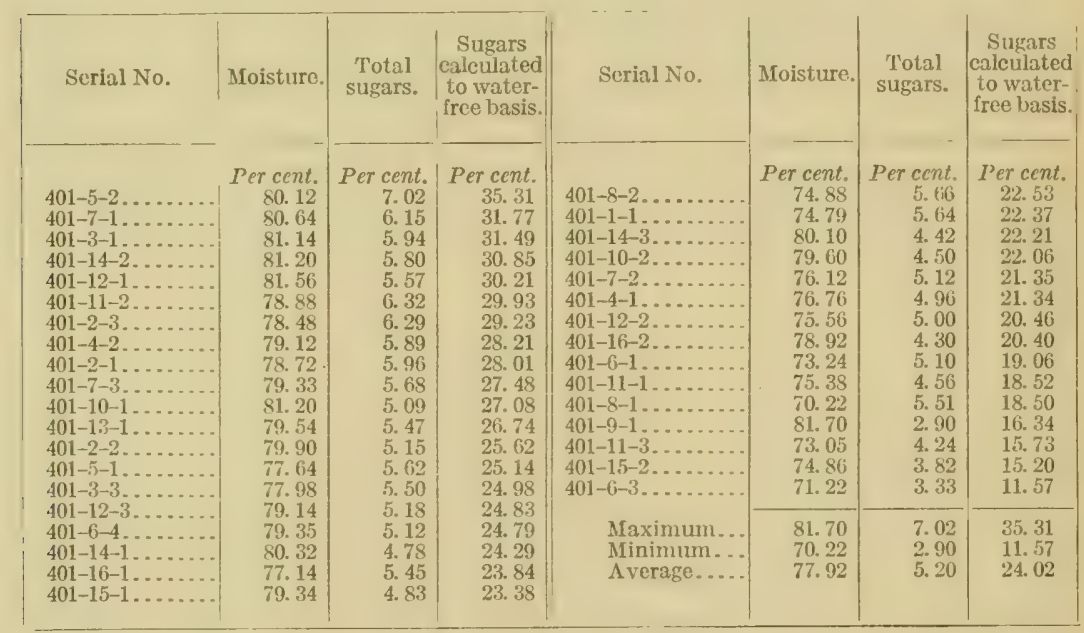

A good crop of corn was produced in Maryland in 1908, and the percentage of sugar was higher than at any other station, this being the second year during the investigations that the Maryland crop showed the highest sugar content.

\section{CONNECTICUT.}

A plat of sandy loam at Orange, Conn., was selected for growing the Crosby corn in 1908, on which corn had been planted in 1905 and 1906 and which had lain idle during 1907. The soil was prepared in the usual mamner and well fertilized with manure and mixed commercial fertilizer-exact amount unrecorded. The seed having been 
planted May '28, the young plants came up. June 8 and tasseled some time between July 17 and 24 . The plat was cultivated three times with a shovel-toothed cultivator and weeded by hand twice. On September 1 the corn reached the edible state and came to full maturity October 16. The cultural data for the Stowell Evergreen are exactly the same except that the plat had been planted with tomatoes in the preceding year. The Stowell Evergreen came up June \&, tasseled July 17, was edible August 25, and was harvested October 16.

The meteorological conditions are shown in the following table:

Meteorological data for New Haven, Conn., 1908.

\begin{tabular}{|c|c|c|c|c|c|c|}
\hline Month. & $\begin{array}{l}\text { Mean } \\
\text { tempera- } \\
\text { ture. }\end{array}$ & $\begin{array}{l}\text { Total } \\
\text { precipi- } \\
\text { tation. }\end{array}$ & $\begin{array}{l}\text { Clear } \\
\text { days. }\end{array}$ & $\begin{array}{l}\text { Partly } \\
\text { cloudy } \\
\text { days. }\end{array}$ & $\begin{array}{l}\text { Cloudy } \\
\text { days. }\end{array}$ & $\begin{array}{l}\text { Rainy } \\
\text { days. }\end{array}$ \\
\hline $\begin{array}{l}\text { May............ } \\
\text { June........... } \\
\text { July .......... } \\
\text { August........ } \\
\text { September.... }\end{array}$ & $\begin{array}{l}{ }^{\circ} F . \\
60.2 \\
69.2 \\
74.6 \\
69.6 \\
65.6\end{array}$ & $\begin{array}{r}\text { Inches. } \\
6.16 \\
1.20 \\
3.94 \\
8.12 \\
.88\end{array}$ & $\begin{array}{l}11 \\
18 \\
13 \\
16 \\
13\end{array}$ & $\begin{array}{r}10 \\
11 \\
14 \\
7 \\
13\end{array}$ & $\begin{array}{r}10 \\
1 \\
4 \\
8 \\
4\end{array}$ & $\begin{array}{r}13 \\
4 \\
8 \\
11 \\
4\end{array}$ \\
\hline
\end{tabular}

Special attention is called to the rainfall data. The corn was harvested between September 1 and 7 . From August 7, when 0.42 inch fell, there were no more rains until $\Lambda$ ugust 11, when 0.19 inch fell; on August 14, 0.1 inch is recorded; on August 17, 0.11 inch; on August 22, 2.93 inches; on August 26, 2.91 inches, and the following day 0.11 inch fell -a total of 8.12 inches for August as compared with 1.21 inches in 1907, when the heary rain came in September. No other rains occurred until the corn was harvested. The mean temperature was higher than for the three previous years.

The analytical data for the Crosby corn are as follows:

Analysis of individual ears of Crosby corn grown at Orange, Conn., 1908.

\begin{tabular}{|c|c|c|c|c|c|c|c|}
\hline Serial No. & Moisture. & $\begin{array}{l}\text { Total } \\
\text { sugars. }\end{array}$ & $\begin{array}{c}\text { Sugars } \\
\text { calcula- } \\
\text { ted to } \\
\text { water-free } \\
\text { basis. }\end{array}$ & Serial No. & Moisture. & $\begin{array}{l}\text { Total } \\
\text { sugars. }\end{array}$ & $\begin{array}{c}\text { Sugars } \\
\text { calcula- } \\
\text { ted to } \\
\text { water-free } \\
\text { basis. }\end{array}$ \\
\hline 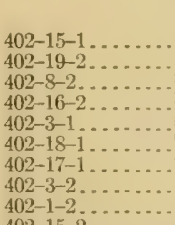 & $\begin{array}{r}\text { Percent. } \\
79.79 \\
77.03 \\
71.86 \\
69.11 \\
82.44 \\
68.96 \\
73.11 \\
70.60 \\
66.06\end{array}$ & $\begin{array}{r}\text { Per cent. } \\
7.06 \\
5.61 \\
\mathbf{6 . 3 8} \\
6.91 \\
\mathbf{3 . 7 1} \\
5.94 \\
5.05 \\
5.30 \\
5.95\end{array}$ & $\begin{array}{r}\text { Per cent. } \\
34.94 \\
24.42 \\
22.67 \\
22.37 \\
21.13 \\
19.14 \\
18.78 \\
18.03 \\
17.53\end{array}$ & 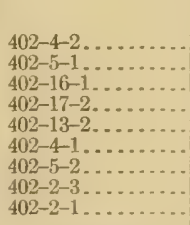 & $\begin{array}{r}\text { Per cent. } \\
67.10 \\
68.03 \\
58.39 \\
70.31 \\
69.22 \\
71.39 \\
64.71 \\
63.20 \\
70.09\end{array}$ & $\begin{array}{r}\text { Per cent. } \\
4.45 \\
4.23 \\
5.45 \\
3.78 \\
3.73 \\
3.31 \\
3.65 \\
3.43 \\
2.43\end{array}$ & $\begin{array}{c}\text { Per cent. } \\
13.53 \\
13.23 \\
13.10 \\
12.73 \\
12.12 \\
11.57 \\
10.34 \\
9.32 \\
8.12\end{array}$ \\
\hline $\begin{array}{l}402-12 \ldots \\
402-19-1 \ldots \ldots \\
402-20-1 \ldots \ldots \\
402-2-2 \ldots \ldots \\
402-8-1 \ldots \ldots\end{array}$ & $\begin{array}{l}75.09 \\
64.85 \\
72.24 \\
67.16\end{array}$ & $\begin{array}{l}4.80 \\
4.06 \\
5.60 \\
4.16 \\
4.48\end{array}$ & $\begin{array}{l}16.30 \\
15.93 \\
14.99 \\
13.64\end{array}$ & $\begin{array}{l}\text { Maximum... } \\
\text { Mlinimum... } \\
\text { Average.... }\end{array}$ & $\begin{array}{l}82.44 \\
63.20 \\
70.12\end{array}$ & $\begin{array}{l}7.06 \\
2.43 \\
4.76\end{array}$ & $\begin{array}{r}34.94 \\
8.12 \\
16.58\end{array}$ \\
\hline
\end{tabular}


The Crosby corn was planted on what was presumed to be a plat well suited to the growing of this ('rop, but an unusually poor stand was secured and in some rows not a single ear could be found. The average percentage of sugars for 1908 was low, being $16.5 \mathrm{~s}$, yet some ears with very high percentage were obtained, the maximum being 34.94. The detailed analytical data were as follows:

Analysis of individual ears of Stowell Evergreen corn grown in Orange, Conn., 1908.

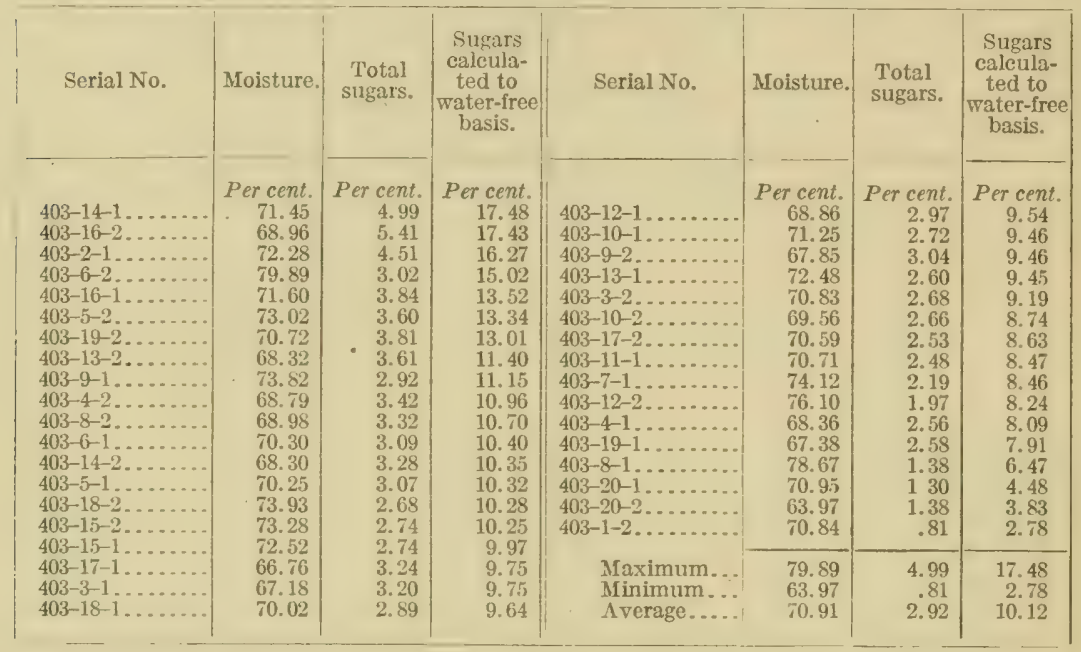

The Stowell Evergreen made a very good stand, having been planted on the same plat of ground as the 1906 crop. For 1908 the average percentage of sugars, however, was only 10.12, with the maximum 17.48 and the minimum 2.78 per cent; while in 1905 the average was 21.70 per cent; in $1906,15.10$ per cent; and in $1907,17.11$ per cent.

The decided drop in the sugar content in this year is of interest in connection with the fact that there was a heary rainfall in August, the month when sugar should have been stored, while the total precipitation was the lowest recorded in the four years for this station.

MAINE.

At the Maine station in 1908 the Crosby corn was planted in soil of the clay type intermixed with shaly rock which had produced a crop of mangel-wurzels the season before. Preparation of the ground consisted of fall plowing and harrowing with a disk harrow twice, with a spike-tooth harrow twice, and with a smoothing harrow once. The fertilizer employed was a commercial mixture containing 3 per cent of nitrogen, 7 per cent of phosphoric acid, and 4 per cent of potassium oxid applied at the rate of 600 pounds per acre. The seed was planted .June s and the young plants appeared one week later. 
The plat was cultivated four times with a spike-tooth harrow and hoed once. The corn reached the edible condition on September 19. The appended table shows the meteorological conditions under which the corn was grown:

Meteorological data for Orono, Me., 1908.

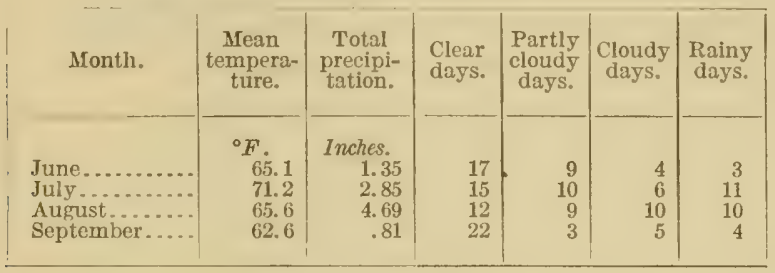

Although the Crosby corn grown at the Maine station in 1908 was second highest in percentage of sugar, still it contained less sugar than in former years. There were more clear days during the growing season in 1908 and the mean temperature was higher than in either of the two preceding years. The rainfall, however, was normal.

The detailed analytical data follow:

Analysis of individual ears of Crosby corn grown at Orono, Me, 1908.

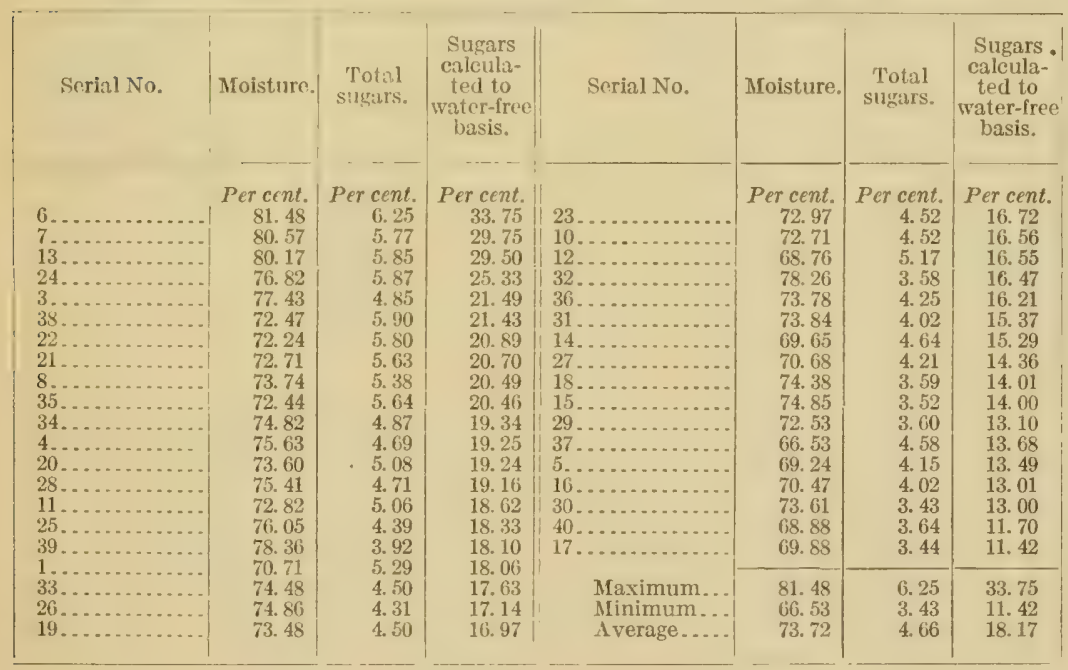

GENERAL, DISCUSSION OF DATA.

The average data, analytical, meteorological, and geodetic, for the year 1908, as shown in the tables of summaries and platted on the graphic chart (fig. 4), confirm in a general way those of the three previous years. The highest percentage of sugars for the Crosby variety was obtained at the South Carolina station, while at the 
Florida station it was as low as in 1906. The Maine station stood second and Connecticut third. In examining figure 4, on which is charted the summary of the analytical data given for the Stowell Evergreen, it will be noticed that Maryland has the highest percentage of sugar for the Stowell Evergreen and South Carolina for the Crosby, exceeding the figure for liaine by 5 per cent. A comparison of the data for $190 \mathrm{~s}$ with those of the three preceding years shows the sugar content in both varieties to be above those for 1906, but below 1905 and 1907 . The average moisture content for the Stowell Evergreen (75.14) is higher than that of the Crosby (72.11).

The percentage of sunshine is practically the same for the Florida and the Connecticut stations, with Maryland next and South Carolina

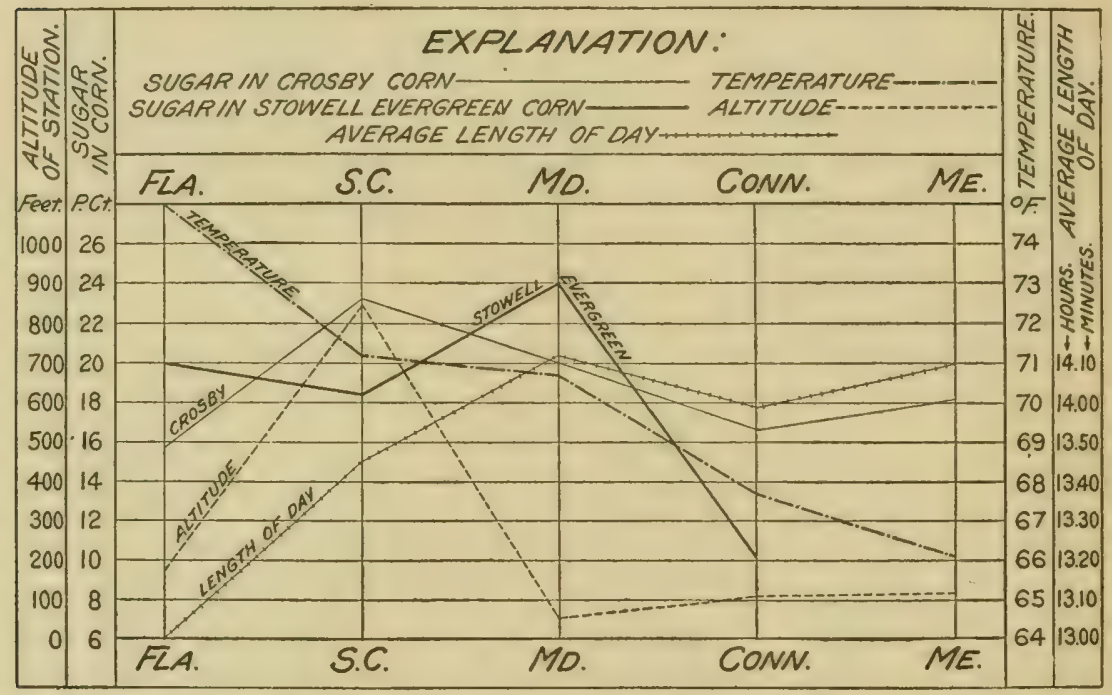

FIG. 4.-Percentage of sugar in the corn, temperature, altitude, and average length of day at the different stations, 1908.

last. Attention should be called to the fact that these data were not obtained at the stations, but at distances varying from 8 miles in the case of the Maryland and Connecticut stations to 30 miles for the Florida station and 100 miles for the South Carolina station. No conclusive deductions can be drawn, therefore, but taking into consideration also the number of clear, cloudy, and partly cloudy days as given for each station, the data confirm the opinion stated in the summary of the 1905 work, namely, that unobstructed sunshine is not necessary to the development of sugar.

In figure 4 is shown the percentage of sugar, together with the average length of day, the temperature, and the altitude of the several stations. The average temperature for the growing season was higher at each station for 1908 than it was for 1907 and the South Carolina figures again show the effect of the high altitude. 
Of all the meteorological data, the distribution of the rainfall appears to be the most potent factor. At the Maryland and Florida stations there fell during the growing season (June and July for the the former, April and May for the latter) apparently just enough rain to satisfy the requirements of the growing crop. The South Carolina station had a fair distribution of rain, and the Connecticut station an excessive rainfall at the period of growth when the sugar was forming. The total rainfall for Maryland was far below the average for this station. The relation between the sugar content and these data is discussed in connection with figures 7 to 11 , inclusive (pages 62 to 67).

SUMMARY OF AVERAGE DATA FOR 1908.

Analytical data for Crosby and Stowell Evergreen corn at five stations, 1908.

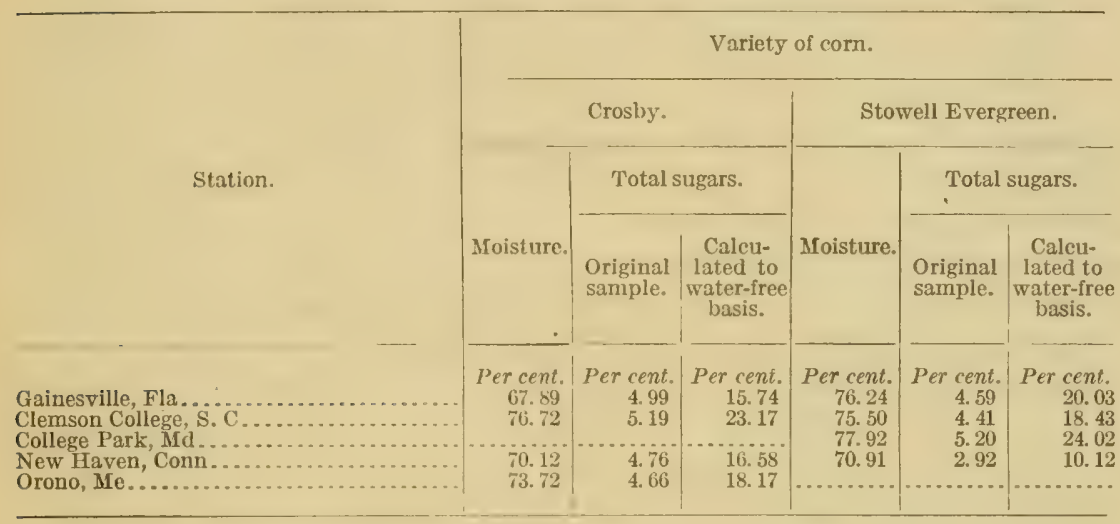

Meteorological data, 1908, for five stations.

Station.

\begin{tabular}{|c|c|c|c|c|c|}
\hline $\begin{array}{l}\text { Mean } \\
\text { tempera- } \\
\text { ture. }\end{array}$ & $\begin{array}{c}\text { Total } \\
\text { precipita- } \\
\text { tion. }\end{array}$ & $\begin{array}{l}\text { Clear } \\
\text { days. }\end{array}$ & $\begin{array}{l}\text { Partly } \\
\text { cloudy } \\
\text { days. }\end{array}$ & $\begin{array}{l}\text { Cloudy } \\
\text { days. }\end{array}$ & $\begin{array}{l}\text { Sun- } \\
\text { shine. }\end{array}$ \\
\hline $\begin{array}{l}\circ F . \\
75.0 \\
71.2 \\
70.7 \\
67.8 \\
66.1\end{array}$ & $\begin{array}{r}\text { Inches. } \\
12.55 \\
19.23 \\
11.92 \\
20.30 \\
9.70\end{array}$ & $\begin{array}{r}a 66 \\
73 \\
63 \\
71 \\
66\end{array}$ & $\begin{array}{l}a 6 \\
35 \\
47 \\
55 \\
31\end{array}$ & $\begin{array}{r}a 19 \\
14 \\
30 \\
27 \\
25\end{array}$ & $\begin{array}{r}\text { Per cent. } \\
\text { b } 74 \\
c 61 \\
d 63 \\
74 \\
\hdashline \ldots . .\end{array}$ \\
\hline
\end{tabular}

$c$ Sunshine given for Atlanta, Ga.

$a$ Data not given for March.
$b$ Sunshine given for Jacksonville, Fla.

d Sunshine given for Washington, D.C.

\section{SUMMARY OF THE FOUR YEARS' WORK.}

\section{GENERAL DISCUSSION.}

In reviewing the investigation, the fact that the corn with the highest percentage of sugar was grown in South Carolina seems of prime importance, since it has always been held that corn grown in the South soon lost its sweetness. South Carolina has held the distinction of producing the highest percentage of sugar in the Crosby corn for three out of the four years, and in 1906 it was practically 
equal to the highest; and for two out of the four years it marle the highest record with Stowell Evergreen. In 1907 and 1908, when South Carolina stood third, it should be noted that Florida and Maryland were the stations producing the corn bearing the highest sugar content, Connecticut being the lowest. The corn does not make so vigorous a growth either in Florida or in South Carolina as it does in Connecticut, but it is as strong as the Maine corn. Maryland corn was much more vigorous than that grown in Florida, South Carolina, or Maine, but did not appear to equal the average Connecticut corn in size of stalk. The kernels of southern-grown corn do not present the same physical appearance as that of the northerngrown corn, both the germ and the kernel being larger in the former.

Referring to the summary of analyses of sweet corn for the four years $1905,1906,1907$, and 1908 , it will be noticed that the sugar content of the Crosby variety is, with a few exceptions, higher than that of the Stowell Evergreen. This would be expected, as a high sugar content is characteristic of the Crosby variety.

Comparing the results of the individual years, the highest sugar values are found in 1905 and the lowest in 1906, while in 1907 the results compare more nearly with those of 1905 , and the 1908 averages are between the two. The extremely high sugar content of the corn grown at South Carolina in 1905 and the low percentage found at New Jersey in 1905 and at Connecticut in 1908 are in all probability due to the distribution of the rainfall. It will be rememberes that during the early stages of growth in New Jersey in 1905 such a severe drought occurred that the Crosby variety of corn did not reach the edible condition, and for a time it was thought that no Stowell Evergreen would be secured, and at the Connecticut station during August, 1908, during the period when the sugars are formed, 8.12 inches fell. During the growing season of 1906 the rainfall was unusually heavy all along the Atlantic coast, and at each station the average sugar content was below the average for 1905, 1907, and 1908.

From the data collected, the amount, and more especially the distribution, of the rainfall appear to be the dominant factors, and a closer interrelation seems to exist between the curves representing rainfall and the percentage of sugar than between any of the other curves. In substantiation of this point the rainfall by periods has been platted for the four years in figures 7, 8, 9, 10, and 11. (For detailed discussion see pages 62 to 67 .)

The summary of the work for the four years has been platted in greater detail than for each year. The percentage of sugar is the average of the Crosby and the Stowell Evergreen for the four years. At the New Jersey station the data for one year are given, and at the 
Florida and Maine stations three years' work has been completerl. The New Jersey experiment is scarcely comparable with the others, as it covers only one year in which the conditions were abnormal and the crop almost a failure. The New Jersey station is therefore omitted in platting the summary for the four years.

In figure 5 a very interesting point is brought out, $i$. e., the effect of temperature on sugar formation, the curve showing that the percentage of sugar varies usually with the temperature. The altitude at the South Carolina station and the fact that only the Croshy variety, having a higher sugar content than the Stowell, was planted in Maine, are factors that must be considered, and may partly explain

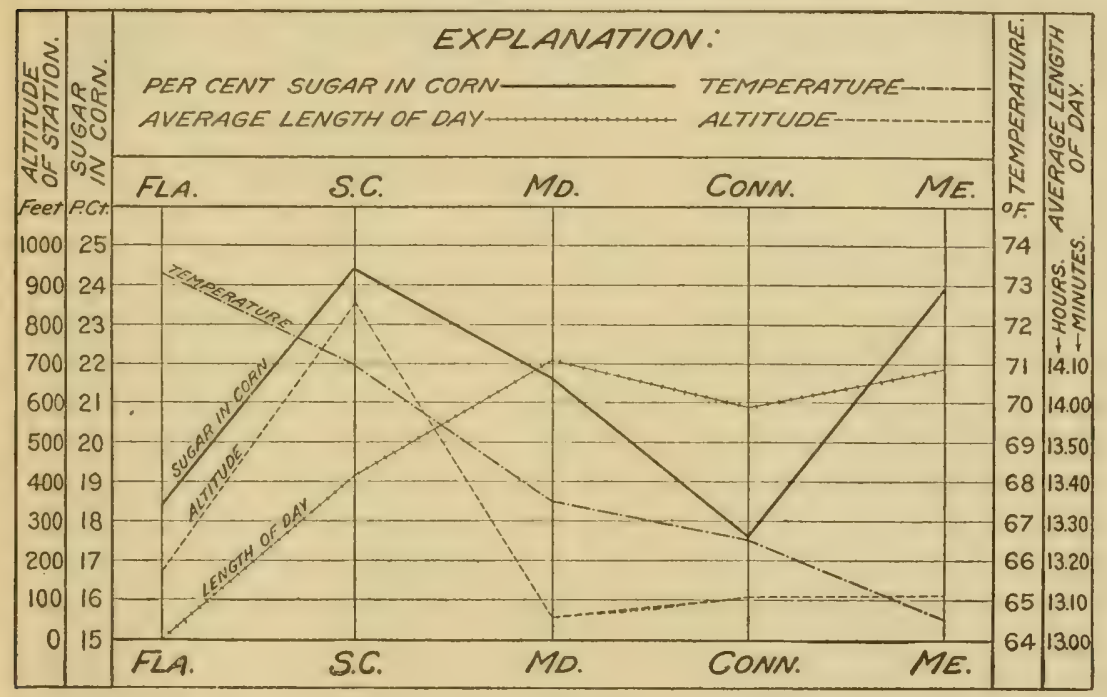

FIG. 5.-Four years' summary: Percentage of sugar in the corn, mean temperature, average length of day, and altitude at the different stations.

the variations at these points. In the environment studies with the beet, however, it was found that the sugar content varied inversely with the temperature. The curve showing the average length of day also follows that for the percentage of sugars very closely. The curve representing altitude appears in the case of the South Carolina station to be an index to the sugar content and undoubtedly has an important bearing on the high results obtained at this point. There is not, however, sufficient difference in the altitude at the other stations to form the basis of a definite general conclusion in regard to this point, and it can only be considered in a general way, being, of course, included in the effect on temperature. As has been stated, the rainfall, and especially its distribution, appear to have more influence on the formation of sugars than any other factor, and the 
curves representing rainfall and percentage of sugars indicate this relation. The intersection of the rainfall and sugar content lines at the Maine station is, in reality, no exception, as less rain is needed in the colder climate.

In figure 6 the line representing the percentage of sugar follows somewhat the percentage line for sunshine. This was even more striking in the 1906 work and is in accord with the accepted theories. Direct sunshine does not, however, appear to control the formation of sugars to quite the extent that has been supposed. In most cases

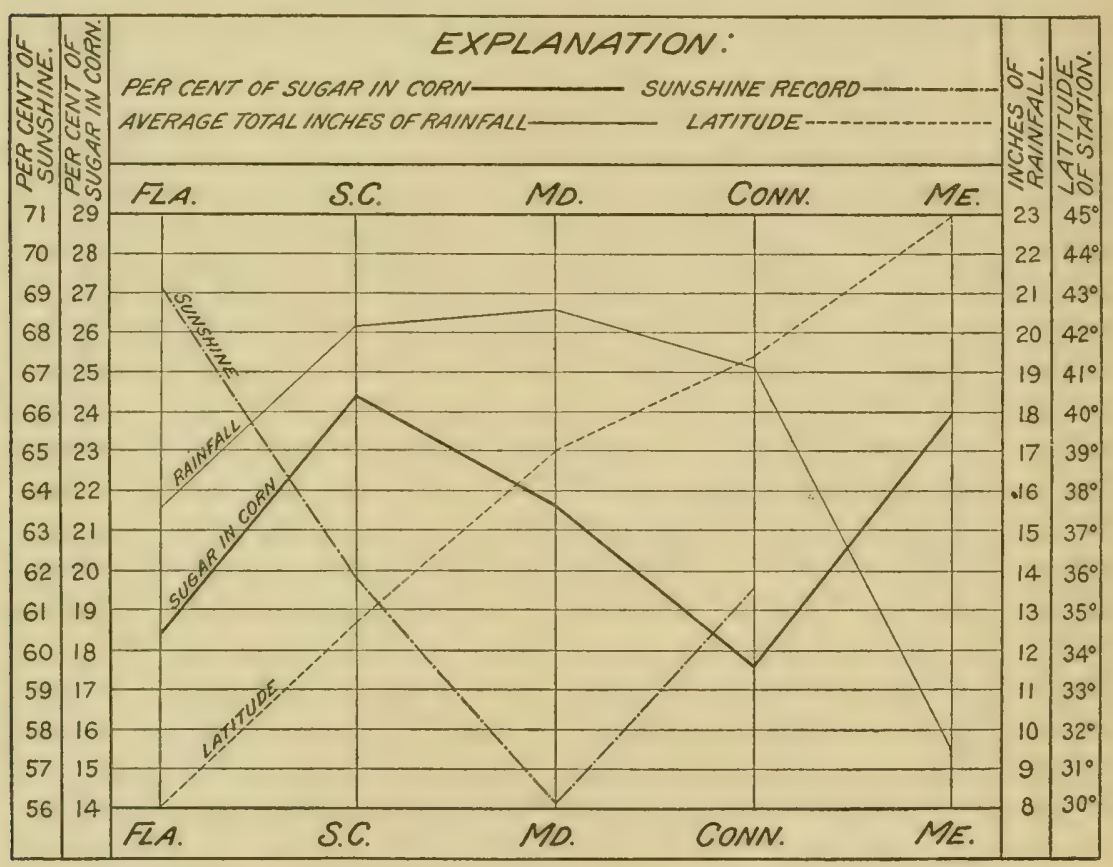

Fig. 6.-Four years' summary: Average percentage of sugar in the corn, sunshine record, rainfall, and latitude of station.

the percentage of sugars varies inversely with the latitude and directly with the temperature, and this fact is in direct opposition to that noted in the studies on sugar beets. Maine, however, constitutes a notable exception.

On comparing the averages of the total sugars for each station, South Carolina shows a percentage of 24.42 and Maine of 23.96. In connection with this it should be borne in mind that the average obtained for South Carolina includes the Stowell Evergreen with the Crosby variety. In Maine only one variety was grown, and that was the Crosby. If the Crosby variety had been used alone for South Carolina, the average would have been 27.21 per cent. 
As the growing season varied widely in different localities (and somewhat at the same stations in different years), the two varieties matured at slightly different times even at the same station, and the period of examination of the edible corn extended sometimes over two weeks, it was impossible to confine the meteorological data to a definite period. Therefore the averages for the four years, given in the following table, include the whole month in which the corn was planterl, and that in which it was harvested, giving the general seasonal conditions. Both precipitation and temperature conditions immediately preceding planting would have their effect on germination and therefore may logically be included. Any heavy rainfalls occurring during the examination of the corn are probably negligible and are therefore excluded from the average, the platted data showing the daily distribution of rainfall indicating the exact conditions.

Summary of analytical and meteorological data, 1905-1908.

[Data averaged for month of planting to month of harvesting, inclusive.]

\begin{tabular}{|c|c|c|c|c|c|}
\hline Stations. & $\begin{array}{l}\text { Total } \\
\text { sugars.a }\end{array}$ & $\begin{array}{l}\text { Mean } \\
\text { tempera- } \\
\text { ture. }\end{array}$ & $\begin{array}{l}\text { Precipi- } \\
\text { tation. }\end{array}$ & $\begin{array}{l}\text { Clear } \\
\text { days. }\end{array}$ & $\begin{array}{l}\text { Sun- } \\
\text { shine. }\end{array}$ \\
\hline $\begin{array}{r}\text { Florida: } \\
\quad 1906 \\
1907 \\
1908\end{array}$ & $\mid$ Per cent. & $\begin{array}{l}\text { F. } \\
71.0 \\
74.0 \\
75.0\end{array}$ & $\begin{array}{l}\text { Inches. } \\
22.66 \\
11.66 \\
12.55\end{array}$ & $\begin{array}{l}34 \\
72 \\
66\end{array}$ & $\begin{array}{r}\text { Per cent. } \\
62.0 \\
71.2 \\
74.0\end{array}$ \\
\hline Average . . . . . . . . . . . . . . . . . . . . . . . . . . . & 18. 41 & 73.3 & 15.62 & 57 & 69.1 \\
\hline 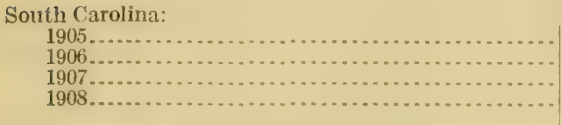 & 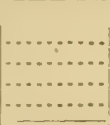 & $\begin{array}{l}72.7 \\
71.6 \\
68.7 \\
71.2\end{array}$ & $\begin{array}{l}19.80 \\
28.07 \\
13.59 \\
19.23\end{array}$ & $\begin{array}{l}80 \\
67 \\
81 \\
73\end{array}$ & $\begin{array}{l}61.0 \\
60.0 \\
65.2 \\
61.0\end{array}$ \\
\hline Average. . . . . . . . . . . . . . & 24. 42 & 71.0 & 20.17 & 75 & 61.8 \\
\hline 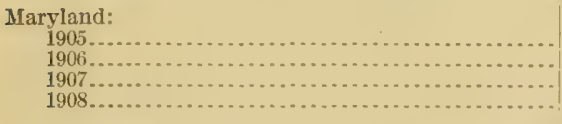 & $\begin{array}{l}\ldots \\
\ldots \ldots\end{array}$ & $\begin{array}{l}68.0 \\
68.4 \\
63.4 \\
70.7\end{array}$ & $\begin{array}{l}24.49 \\
28.88 \\
16.95 \\
11.92\end{array}$ & $\begin{array}{r}104 \\
50 \\
58 \\
63\end{array}$ & $\begin{array}{l}52.0 \\
53.0 \\
56.6 \\
63.0\end{array}$ \\
\hline 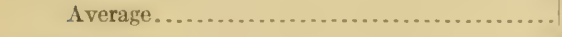 & 21.66 & 67. 6 & 20.56 & 69 & 56.1 \\
\hline $\begin{array}{l}\text { New Jersey: } \\
1905 \ldots \ldots \ldots \ldots \ldots \ldots \ldots \ldots\end{array}$ & 14.12 & 68.0 & 16.91 & 87 & 61.0 \\
\hline 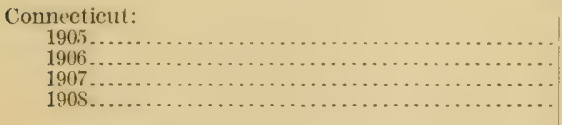 & $\begin{array}{l}\ldots \ldots \ldots \\
\cdots \ldots \ldots \\
\cdots \ldots \ldots \\
\cdots \ldots \ldots \\
\end{array}$ & $\begin{array}{l}66.2 \\
67.8 \\
64.6 \\
67.8\end{array}$ & $\begin{array}{l}17.11 \\
21.46 \\
17.58 \\
20.30\end{array}$ & $\begin{array}{l}45 \\
56 \\
60 \\
71\end{array}$ & $\begin{array}{l}60.0 \\
55.0 \\
57.2 \\
74.0\end{array}$ \\
\hline 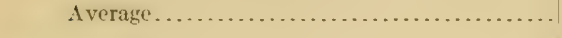 & 17.59 & 66.6 & 19.11 & 58 & 61.5 \\
\hline 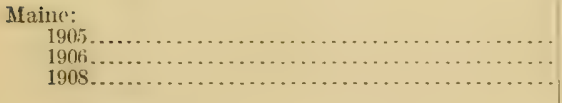 & \begin{tabular}{ll|}
$\ldots \ldots \ldots$ \\
$\cdots \cdots$ \\
$\cdots \cdots$
\end{tabular} & $\begin{array}{l}62.7 \\
65.0 \\
66.1\end{array}$ & $\begin{array}{r}10.64 \\
8.53 \\
9.70\end{array}$ & $\begin{array}{l}45 \\
53 \\
66\end{array}$ & (n) \\
\hline 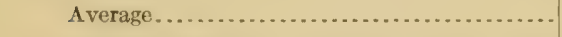 & 23.96 & 64.6 & 9.62 & 55 & $\ldots \ldots \ldots$ \\
\hline
\end{tabular}

a Average of Crosby and Stowell Evergreen corn calculated to water-free basis. 
Summary of analytical data for four stations, 1905-1908.

CROSBY VARIETY.

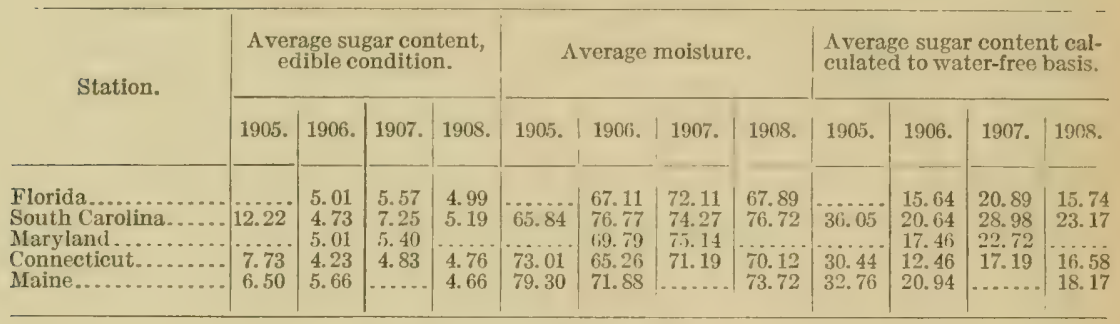

STOWELL, EVERGREEN VARIETY.

\begin{tabular}{|c|c|c|c|c|c|c|c|c|c|c|c|c|}
\hline \multirow{2}{*}{$\begin{array}{l}\text { Florida } \\
\text { South Carolina..... } \\
\text { Maryland ............ } \\
\text { New Jersey........ } \\
\text { Connecticut....... }\end{array}$} & \multirow{2}{*}{$\begin{array}{l}6.68 \\
5.78 \\
4.26 \\
5.36\end{array}$} & $\begin{array}{l}4.07 \\
4.99 \\
3.77\end{array}$ & $\begin{array}{l}5.43 \\
\text { 4. } 95 \\
4.83\end{array}$ & $\begin{array}{l}4.59 \\
4.41 \\
5.20\end{array}$ & \multirow{2}{*}{$\begin{array}{l}75.54 \\
78.13 \\
69.28 \\
74.62\end{array}$} & \multirow{2}{*}{$\begin{array}{c}70.27 \\
71.72 \\
72.34 \\
73.38\end{array}$} & \multirow{2}{*}{$\begin{array}{c}77.08 \\
76.82 \\
80.59 \\
78.20\end{array}$} & \multirow{2}{*}{$\begin{array}{c}76.24 \\
75.50 \\
77.92 \\
70.91\end{array}$} & \multirow{2}{*}{$\begin{array}{l}27.95 \\
27.18 \\
14.12 \\
21.70\end{array}$} & \multirow[t]{2}{*}{$\begin{array}{l}13.94 \\
18.07 \\
13.61 \\
15.10\end{array}$} & \multirow{2}{*}{$\begin{array}{l}24.25 \\
22.05 \\
24.97 \\
17.11\end{array}$} & \multirow{2}{*}{\begin{tabular}{l}
20.03 \\
18.43 \\
24.02 \\
\hdashline 10.12
\end{tabular}} \\
\hline & & 3.92 & 3.69 & 2.92 & & & & & & & & \\
\hline
\end{tabular}

\section{DISTRIBUTION OF RAINFAIL.}

In platting the daily distribution of rainfall the data for 1905 were not included, as no work was performed at the Florida station and only one variety of corn was planted in Maryland, New Jersey, and Maine. The period platted extends from the time when the first tassels appeared until work on the edible corn was discontinued, and the charts are based primarily on the Crosby corn, the Stowell Evergreen being usually about ten days less ardvanced. From the time of tasseling to the commencement of work on the edible corn is a periorl of from twenty-eight to thirty-five days, and this has been divided into sections of seven days each to facilitate the study of the distribution of the rainfall.

At the Florila station (fig. 7) in 1906 rains occurred very frequently and they are the heaviest recorded. The two weeks following the tasseling show eight rainfalls with a total of 7.7 inches. During the third week no rain fell, but in the fourth week, just before the corn reached the edible stage, there were five rains giving a total precipitation of 0.8 inch, the record for the next day being 3 inches. During the period of harvest there were three more rains, the precipitation being 1.4, 0.84, and 1.12 inches, respectively, making a total of 3.36 . From these data it would appear that as much as 14 inches of rain fell in the period from the time of tasseling to the harvesting of the corn-an excessive rainfall, explaining entirely the low sugar content recorded, even though more rain is required in this latitude than farther north.

The chart for 1907 shows six rains with a total precipitation of 3.7 inches during the twelve days following the period of tasseling. This is less than half of the amount recorded for the corresponding time in 
1906. During the following two weeks no rain fell, the next rains being recorded when the corn was edible ( 1 inch) and during the harvesting period $(0.15$ inch). The sugar content for this year exceeds that of 1906 by 5 and 10 per cent for the Croshy and Stowell Evergreen, respectively, and is greater than the figures for 1908 by 5 and 4 per cent.

Frequent light rains are recorded for 1908 , two rains with a total precipitation of 0.7 inch on the second and third day after tasseling, and daily rains from the twelfth to the fifteenth day, inclusive, with the same small total precipitation. No further rainfall occurred until harvest time, when there was a precipitation of 2.15 inches, distributed

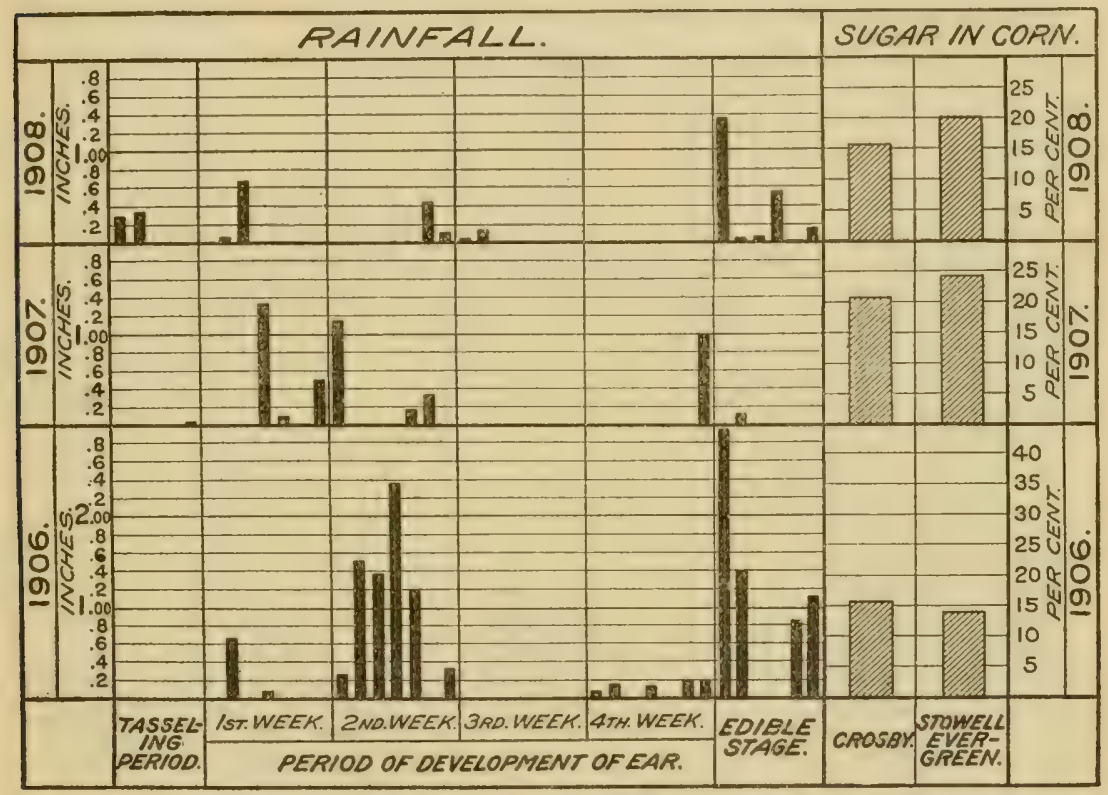

FIG. 7.-Daily distribution of rainfall by periods for 1906, 1907, and 1908 at the Florida station.

over five consecutive days. For the entire four weeks preceding the season of harvest six rains are recorded and 1.4 inches of rainfall.

From these data it would appear that excessive rainfall during the first two weeks after tasseling interferes decidedly with the storage of sugars, while the very light rainfall during the following two weeks represented almost ideal conditions. The undesirable conditions of 1906 are obvious, while 1907 and 1908 differ but little in total amount of rain (11.66 and 12.55 inches, respectively), both being less than the total for 1906 by about 10 inches. The superiority of the conditions of 1907 over 1908 was almost entirely due to distribution, as in 1907 the heavier rains fell during the first two weeks of growth, when needed most, while there was very little rain in 1908 during that period. The effect of the distribution and 
amount of the rainfall on the sugar content would seem to be clearly indicated in this case.

At the South Carolina station (fig. 8) in 1906 seven rains occurred during the period of tasseling, a total of 3.9 inches. No rain fell for the first two weeks of the growing period, when it was most needed, and in the second half of the growing period a total of twelve rainfalls amounting to 13.20 inches is recorded, and in three cases these are heavy, amounting to 1.2, 1.7, and 3 inches, respectively. Again the data show that the sugar content of the corn was markedly low in 1906, accompanied by excessive rainfall both as to number and amount of precipitation, and an unfavorable distribution-that is,

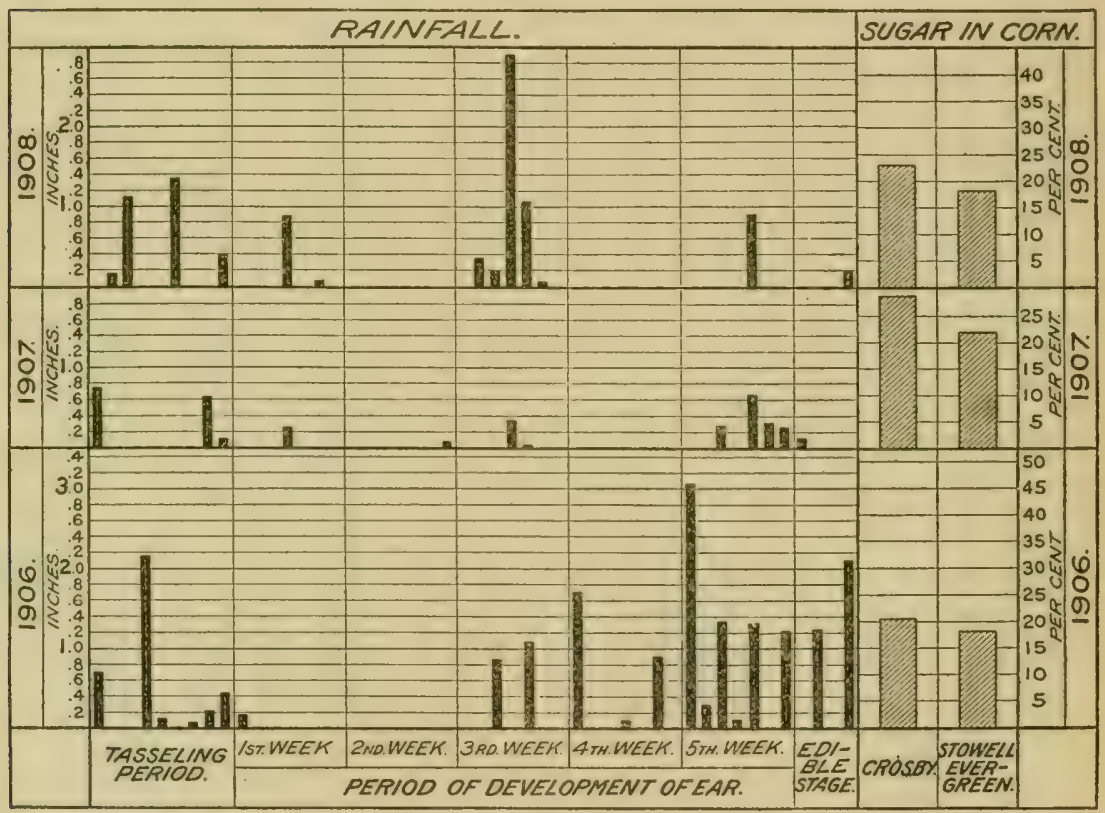

FIG. 8.-Daily distribution of rainfall by periods for 1906, 1907, and 1908 at the South Carolina station.

no rain in the early weeks of growth and heavy frequent rainfalls in the later weeks, from which a diminution in the storage of sugars would be expected.

In 1907 three rains (1.5 inches) occurred during tasseling. In the first half of the growing period four rains (0.82 inch) fell. For almost two weeks in the latter half of the period no rains occurred, and in the week just prior to harvesting five rains are recorded, amounting to 1.65 inches. Again, the 1907 crop contains much more sugar than that of 1906 or 1908 , exceeding the figures for 1906 by 8 and 4 per cent, respectively, for the Crosby and Stowell Evergreen varieties. The year was marked by the absence of heavy precipitation and many small, well-distributed rainfalls, obviously ideal conditions in this regard and in strong contrast to those of 1906. 
In 1908 there were four rains during the period of tasseling, a precipitation of 3.03 inches, and for the first half of the period of growth five rains (4.39 inches) are recorded, the second half showing a precipitation of only 2 inches clistributed in three rainfalls. The sugar content for this year is the same as for 1906 in the case of the Stowell Evergreen and 2.5 per cent higher for the Crosby, occupying an intermediate position between 1906 and 1907 . This coinciles with the general theory as to the effect of the rainfall, since the 1908 rainfall, while fairly well distributed, is more abundant than that of 1907 and was rather infrequent in the early growing season and plentiful

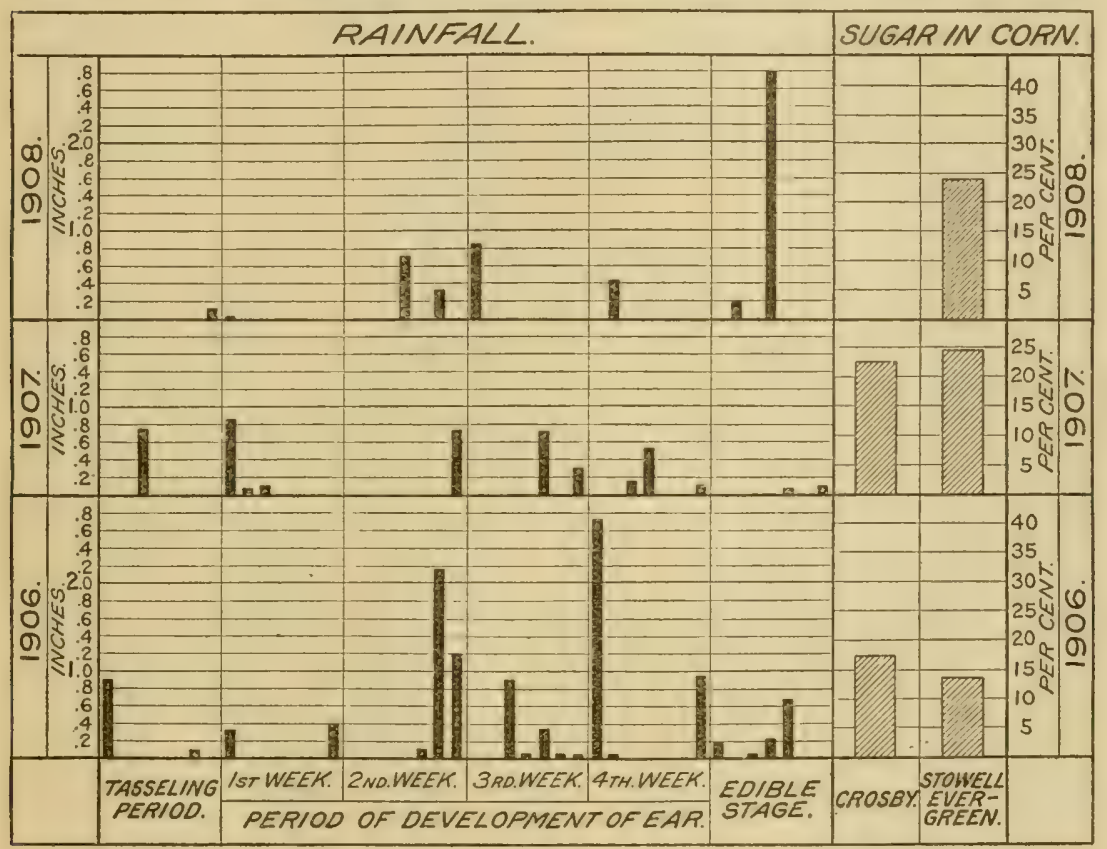

FIG. 9.-Daily distribution of rainfall by periods for 1906, 1907, and 1908 at the Maryland station.

during the last week of development, the reverse condition being desirable.

At the Maryland station (fig. 9) the total rainfall for 1906 was excessive, two especially heavy rains of over 2 inches occurring in the latter part of the growing period, three of about an inch, and five slight rains, this condition being again accompanied by the minimum sugar content in the three years. The Crosby contained over 5 per cent more sugar in 1907 than in 1906 and the Stowell Evergreen over 11 per cent more in both 1907 and 1908. During the period in which the corn was tasseling three rains fell, a total precipitation of 1.3 inches. Four-tenths of an inch of rainfall was recorded for the shower occurring in the following week. A succession of rains4925-Bull. $127-09-5$ 
nine in thirteen days with a total precipitation of 7.6 inches-is next recorded, and two days prior to the harvesting time there was another rainfall, amounting to 0.95 inch.

In 1907 two rains in the tasseling period gave a precipitation of 1.52 inches; the next week 0.15 inch fell in two days followed by ten days with no rainfall, when 0.75 inch is recorded. $\Lambda$ gain five clear days occurred and in the ten days before harvest five additional rains are recorded, aggregating a total of 1.95 inches. The chinted data shown in figure 9 indicate much less rainfall than in 1906, especially during the latter part of the season, although a sufficient quantity fell to meet the needs of the growing plant. The sugar content, as would be expected, is much higher than in the previous

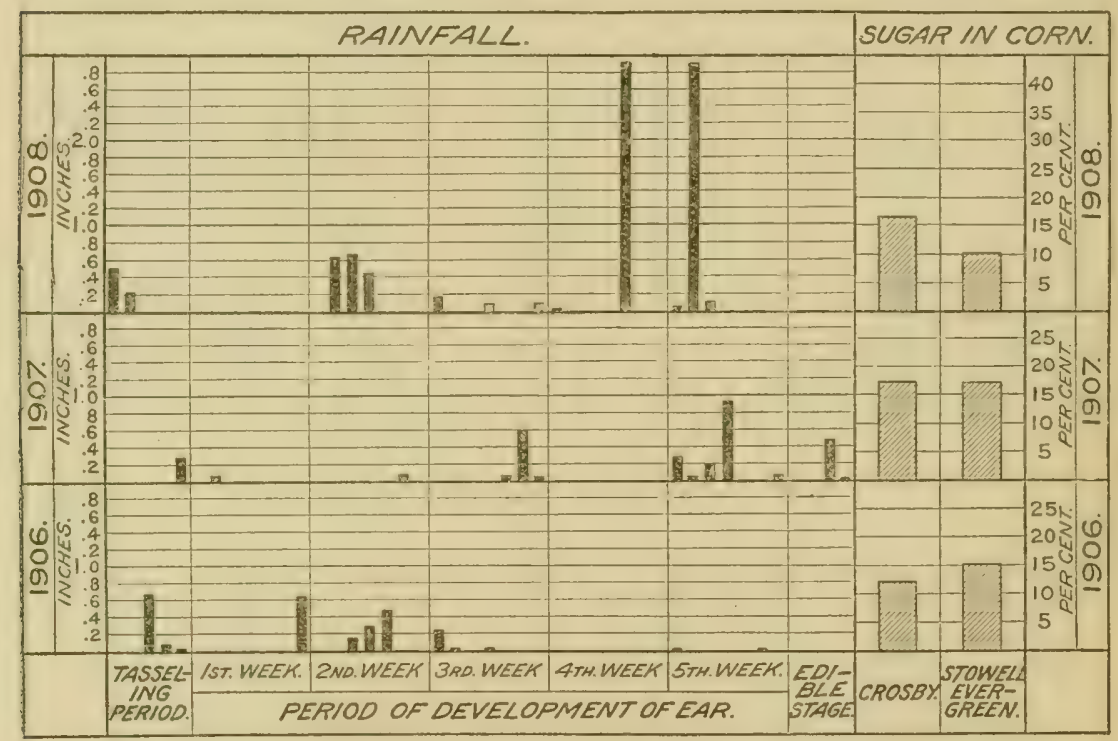

FIG. 10.-Daily distribution of rainfall by periods for 1906, 1907, and 1908 at the Connecticut station.

year, and furnishes another striking example of the effect of frecuent slight precipitations.

The record for 1908 shows two light rains during the tasseling period; three rains (1.92 inches) occurred in the second week thereafter, and one more $(0.42$ inch $)$ a few days before the harvest. The sugar content of the corn for this year compared very favorably with that of $190 \%$, being only slightly less, and the rainfall data parallel each other closely.

$\Lambda$ the Connecticut station (fig. 10) the 1906 and 1908 data are comparable until the fourth week after tasseling, when the chart for 1908 shows two rainfalls in one week of over 2.9 inches each. The Stowell Evergreen corn shows markedly the disastrous effects of these heary rainfalls, being 7 per cent lower in sugar than in 1907 
and 5 per cent less than in 1906 . The Crosby corn, however, has only slightly less sugar in 1908 than in 1907, and it is of interest to note that this variety had practically matured before the two heavy rainfalls mentioned while the Stowell Evergreen was two weeks younger. The 1906 data are more favorable in this case, the rains not being excessive as at the other stations, but on the contrary only two rains are recorded during the latter part of the growing period, amounting to only 0.2 inch, the more important rainfalls occurring during the first two weeks after tasseling.

The year 1907 is again marked by a rather small rainfall, but it is not so well distributed as at the other stations, there being only two rains during the first two weeks, followed by rather frequent though morlerate rains up to the time of harvest. While these data are hardly to be called contradictory, the effect of the distribution

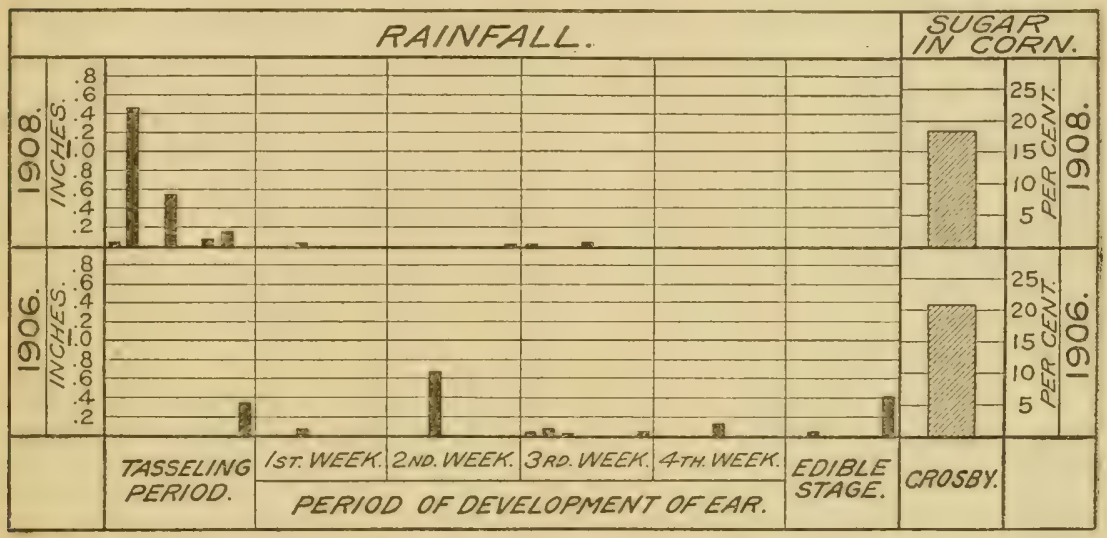

FrG. 11.-Daily distribution of rainfall by periods for 1906 and 1908 at the Maine station.

of rainfall is not so striking in this case except in so far as the 1908 crop is concerned, the 1906 crop remaining low in sugar despite the more favorable rainfall conditions.

The Maine station (fig. 11) shows a low rainfall for both 1906 and 1908 , especially the latter year, when only four rains with an aggregate of 0.08 inch fell after the period of tasseling, evidently not a sufficient supply even in a colder climate where less moisture is necessary. There is also a better distribution of rain for 1906 and the analyses show more sugar for this year, exceeding 190 s hy nearly 3 per cent.

While the problem is too complicated for its solution to rest with any one factor, the data for the several stations indicate that within reasonable limits, and when none of the other conditions are extremely untoward, it is on the even distribution of a very moderate rainfall more than any other one factor that the sugar content depends. Excessive rainfalls at any time, and particularly during the latter part of the growing season, tend to decrease the sugar content. 


\section{GENERAL CONCLUSIONS.}

By H. IV. Wiley.

1. The content of sugar in sweet Indian corn does not depend so much on temperature and length of day as is the case with the sugar beet. In the latter case the content of sugar varies inversely with the temperature, provided the latter is such as to permit normal growth. In other words, the lower the temperature during the growing season (within reasonable limits) the higher the content of sugar. This does not appear to be the case with sweet Indian corn, since a higher average sugar content is found in South Carolina and Florida than in Connecticut and Maine.

2. The content of sugar in sweet Indian corn rapidly diminishes after the ear is separated from the stalk. The speed of the diminution depends largely on the temperature, being more rapid with a higher and slower with a lower temperature; this rule, of course, applies to ordinary conditions. This disappearance of the sugar is doubtless due to the continued growth of the grains of the ear and the transformation of the sugar which they contain into starch or some other form of nonsaccharine carbohydrate. Sweet Indian corn intended for the table, therefore, should be harvested as short a time as possible before being delivererl for consumption, and during the intermediate period should be kept at as low a temperature as can be secured without freezing.

3. The chief ralue of Indian corn for the table is found in its swectness, although this must be coupled with succulence and tenderness. The flavor of the naturally sweet Indian corn can not be successfully imitated by the artificial addition of sugar. Ifence it follows that there is some particular form in which the sugar is combined by nature in the corn which gives it its high ralue, and mere sweetness, produced either by added cane sugar or by saccharine, does not give the fine flavor of a naturally sweet product.

4. The chief difference between the Indian corn of the extreme North and that of the extreme South is found not so much in its content of sugar as in its succulence, the lower temperatures of the North making the corn more tender and edible for a longer period than the extremely high temperatures of the South. The season, therefore, during which the green Indian corn can be used and kept in good condition is longer in the North than it is in the South; in other words, the ripening process is not so rapidly completed in the North. Further, although the southern-grown corn was superior in sugar content it was inferior in yield and general physical appearance. It would appear, howerer, that the superiority in sugar content of the southern corn opens up a possibility of acclimating the most favorable varieties and by selection and careful cultivating greatly improving the southern-grown product. 
5. Of all the factors of the environment which aflect the edible quality of green Indian corn it appears that the amount and distribution of rainfall are the most important. I morlerate and welldistributed rainfall, especially during the growing season, is necessary to produce a crop haring the best qualities. Excessire rainfall in the latter part of the growing season or a great deficiency during the germinating and growing period equally interferes with the excellence of the crop. Naturally, a larger rainfall is needed in the Southern than in the Northern States, and in fact it seems to be more important that it be evenly distributed there. This idea leads to the suggestion that the rery best results in the growing of sweet Indian corn for consumption in the green state may be looked for in the irrigated regions, where the supply and distribution of water are under absolute control. The cost of land, however, in such localities is so great as to render farming more expensive, and hence the great areas devoted to the production of green Indian corn will probably continue to be found in the northern portions of our country where usually the rainfall during the growing period is distributed in such a manner as produces the best crop. The great areas of sweet corn will, therefore, still be found on the Atlantic coast from Maryland north and in the northern parts of the States bordering the Ohio River, and even touching, in some places, the Canadian frontier.

6. From the data which have been recorded and from the general summary it is evident that the graphic representations of the influences of environment in the case of green Indian corn are not so valuable as was the case with the sugar beet. The curves showing variations in temperature, latitude, and altitude, the amount of sunshine, and the quantity and distribution of the rainfall, can not be so readily compared with the lines showing the sugar content as in the case of the sugar beet. The graphic charts, however, are of use in showing the general relations which exist, especially between the content of sugar and the rainfall and temperature, but they can only be properly studied in connection with the careful reading of the text. 










\section{LIBRARY}

| IDI III OF CONGRES

0000935350 J

00009353501 